WSRC-TR-97-0042/WSRC

\title{
Clemson Final Report - High Temperature Formulations for SRS Soils
}

by

R. F. Schumacher

Westinghouse Savannah River Company

Savannah River Site

Aiken, South Carolina 29808
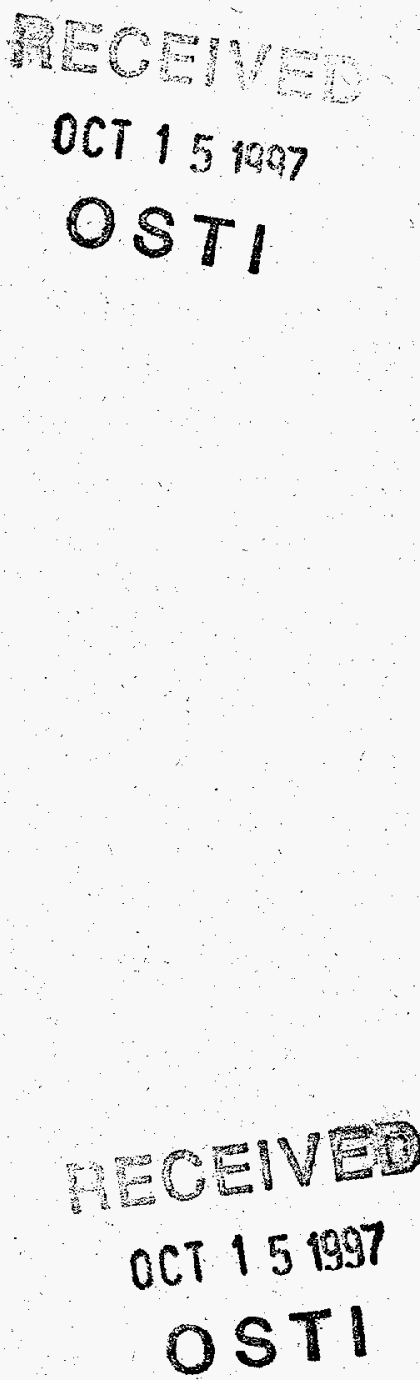

DOE Contract No. DE-AC09-96SR18500

This paper was prepared in connection with work done under the above contract number with the U.S. Department of Energy. By acceptance of this paper, the publisher and/or recipient acknowledges the U. S. Government's right to retain a nonexclusive, royalty-free license in and to any copyright covering this paper, along with the right to reproduce and to authorize others to reproduce all or part of the copyrighted papet.

ESTRIBUTION OF MIS DOCUMENT IS UNLIMTTED

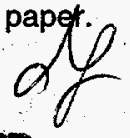




\section{DISCLAIMER}

This report was prepared as an account of work sponsored by an agency of the United States Government. Neither the United States Government nor any agency thereof, nor any of their employees, makes any warranty, express or implied, or assumes any legal liability or responsibility for the accuracy, completeness, or usefulness of any information, apparatus, product, or process disclosed, or represents that its use would not infringe privately owned rights. Reference herein to any specific commercial product, process, or service by trade name, trademark, manufacturer, or otherwise does not necessarily constitute or imply its endorsement, recommendation, or favoring by the United States Government or any agency thereof. The views and opinions of authors expressed herein do not necessarily state or reflect those of the United States Government or any agency thereof.

This report has been reproduced directly from the best available copy.

Available to DOE and DOE contractors from the Office of Scientific and Technical Information, P. O. Box 62, Oak Ridge, TN 37831; prices available from (423) 576-8401.

Available to the public from the National Technical Information Service, U. S. Department of Commerce, 5285 Port Royal Road, Springfield, VA 22161. 


\section{DISCLAIMER}

Portions of this document may be illegible electronic image products. Images are produced from the best available original document. 
To:

Circulate: $\underline{\text { SRTC }}$

E.W. Holtzscheiter, 773-A

Dave A. Crowley, 773-43A

E.F. Duhn, 773-A

H.F. Sturm, 773-A

M.A. Ebra, 773-A

D. F. Bickford, 773-43A

D.T. Herman, 773-41A

M.A. Phifer, 773-42A

Circulate: E.R. Engineering

R.F. Blundy 730-2B

P.G. Zionkowski, 730-2B

Circulate: DOE-SR

S. McMullin, 703-46A

W.C. Laveille, 703-A

G. Mishra, 703-A

C. Johnson, 703-A 
Westinghouse Savannah River Company Page 1 of 3

\section{WSRC-TR-97-0042 Revision 0}

Keywords: plasma, in-situ, vitrification, soil, glass waste form, DC graphite arc.

Retention Time: Permanent

March 11, 1997

To: D.A. Crowley, 773-43A

From: R.F. Schumacher, SRTC 773-43A

(725-5991)

R75 $3 / 11 / 97$

D.T. Herman, SRTC 773-41A (725-5898)

A.L. Sadler, (Retired)

Clemson Final Report - High Temperature Formulations for SRS Soils (U)

\section{SUMMARY}

Previous experience with in-situ (Joule-heated) vitrification (ISV) of Savannah River Site (SRS) highly weathered soils has shown that the SRS soil was both very refractory and a poor electrical conductor. These findings bring into question the likelihood of utilizing this type of vitrification treatment for waste sites and basins at SRS. An alternative approach may be in-situ plasma vitrification (ISPV). The ISPV approach also has a safety advantage in that the melting is initiated at the bottom of a bore hole compared to top-down melting for Joule heated ISV.

Vitrification research utilizing DOE Landfill Focus Area funds was recently completed. A series of experiments on flux additions to the SRS soil was evaluated at the Clemson DOE-Industrial Center for Vitrification Research. Three flux additions were evaluated in high-temperature crucible tests and DC graphite arc furnace studies. The three additives selected were colemanite, dolomitic lime, and hydrated lime. Of the three additives, the dolomitic lime material was the most advantageous fluxing additive. A level of about 25 weight percent was required to reduce the melting temperature into the $1500^{\circ} \mathrm{C}$ range. This material was successfully fed through the primary graphite electrode in the Electro Pyrolysis DC arc melter to the region of the plasma arc over the SRS soil. Analysis of the offgas streams revealed very high particulate content and very low oxygen content. Only trace amounts of hydrogen and carbon monoxide were detected. Dry flux injection is potentially feasible. Glass and soil analyses for samples obtained from these studies will be presented in a later report.

\section{INTRODUCTION}

In-situ vitrification of radioactive and hazardous waste sites by Joule heating is a commercially developed technology (Geosafe Corporation) with hundreds of tests and fairly extensive commercial demonstrations. It should be noted that during the testing there have been a small number of glass or hot gas expulsions from the melt. 
This process utilizes the passage of large electrical currents through the soil between graphite electrodes to provide the thermal energy required to melt the soil. The melt is initiated on the surface and as the melt progresses deeper into the earth the electrodes are gradually lowered. Initial attempts to use this technology for the Savannah River Site (SRS) were not successful due to the low electrical resistivity and refractory nature of the SRS soils. In order to achieve vitrification of the SRS soils it would be necessary to mix or saturate the SRS soils with a suitable flux or generate extremely high temperatures in the vitrification regions. The SRS soils would be representative of other highly weathered sedimentary coastal regions of the United States.

Utilizing funding from DOE's Office of Science and Technology (OST), investigations were undertaken at two regional Universities to study soil additives and in-situ plasma arc vitrification of SRS soils. This report presents the conclusions of the Clemson University study on the addition of additives to the SRS soil. The results from the Georgia Institute of Technology will be distributed in the near future.

\section{BACKGROUND}

Based on previous high-temperature vitrification studies on SRS soils(1-2), the Land-Fill Stabilization and Containment Focus Area (SR-16LF-52), under the DOE Office of Science and Technology, funded an additional study of in-situ vitrification additives at Clemson University. This study was initiated early in FY 96 and completed with the release of the report included as Appendix A. A SCUREF Task Order, No. 187, was prepared and approved to start in January of 1996. This task was to be completed within nine months at a total cost of $\$ 65,500$.

The goal of this effort was to conduct crucible-melt studies with potential soil additives and demonstrate the feasibility of high-temperature melting technology with the ElectroPyrolysis Inc. DC electric arc melter.

\section{CONCLUSIONS}

The experimental procedures and detailed conclusions are presented in the attached final report - See Appendix A.

\section{REFERENCES}

1. C.A. Cicero, D.F. Bickford, W.O. Crews, A.L. Kielpinski, J.C. Marra, A.A. Ramsey, R.F. Schumacher, and T.L. Spatz, "Vitrification of Savannah River Site Contaminated Soils, "Emerging Technologies in Hazardous Waste Management VII., D.W. Tedder (Ed.), Washington, DC, American Chemical Society, pg. 616$618,1995$.

2. A.L. Kielpinski, J.C. Marra, J. Etheridge, R.Kirkland, R.F. Schumacher, and V. Rogers, "Development of Plasma Vitrification Technology for Contaminated Soil at the Savannah River Site," Tuscon Waste Management 95, OSTI as DE05060091, WSRC-MS-95-0056. 
Westinghouse Savannah River Company

Page 3 of 3

WSRC-TR-97-0042

Revision 0

\section{APPENDIX A}

Final Report on High Temperature Vitrification Formulation Demonstration for SRS Contaminated Soils by D.L. Erich, T.J. Overcamp, M.Speer, D.M. Cash, S.J. Griner, Received January 22, 1997. 


\section{FINAL REPORT \\ ON \\ HIGH TEMPERATURE VITRIFICATION \\ FORMULATION DEMONSTRATION FOR SRS \\ CONTAMINATED SOILS}

SCUREF Task Order \#187

Clemson University Project \#6338

by

Donald L. Erich

Thomas J. Overcamp

Matthew Speer

Douglas M. Cash

Stewart J. Griner

January 22, 1997

DOE/Industrial Vitrification Laboratory

Environmental Systems Engineering

Clemson University

342 Computer Court

Anderson, South Carolina 29625 


\section{TABLE OF CONTENTS}

EXECUTIVE SUMMARY -

INTRODUCTION -.-1- 2

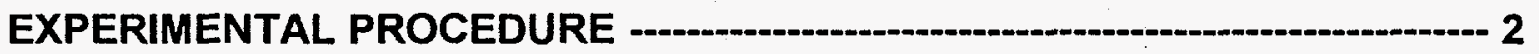

Description of the DC Arc Melter-__ 2

Furnace Assembly - 3

Electrode Assembly-1

Offgas System -

Water Cooling System - 5

Nitrogen Purge System-1- 5

Electrical Power Supply-_- 5

Melter Operation -6

Equipment Modifications_-____- 6

Flux Feeder Design and Operation - 6

Hollow Electrode Design -

Off-gas System Changes -.......-_- 8

Purge Gas System Modifications -

Video Camera -

Description of the Soils-_-10

Crucible Studies _-10

Crucible Study Run Plan-10

Arc Melter Runs ___ 14

Data Acquisition-___ 16

Gas Analyses -

Sample Gas Conditioning-16

Gas Chromatograph Analysis -

EPA Method 5 Sampling-16

RESULTS AND DISCUSSION

Crucible Studies

Arc Melter Runs —__ 22

Run 1 (ID\# 014)-22

Run 2 (ID \#015) -

Run 3 (ID \#016) - 


\section{LIST OF TABLES}

TABLE I Normalized SRS Clay AND SANDY Soll CompostTIONS ....................................................10

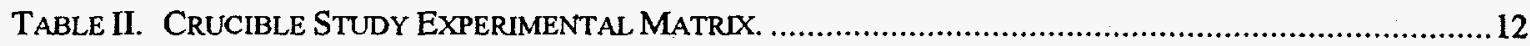

TABLE III. LOD/LOI RESULTS, CALCULATED BATCH CHEMISTRIES AND AMOUNTS WEIGHED ......................13

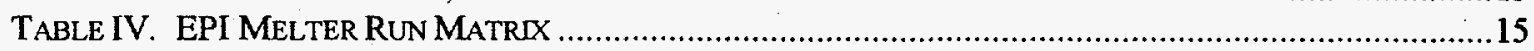

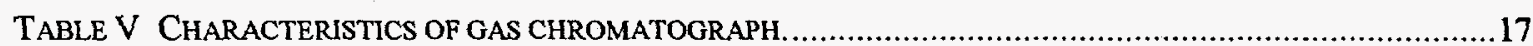

TABLE VI. CRUCIBLE STUDY RESULTS FOR THE INITIAL 16 SCHEDULED TRIALS: ....................................21

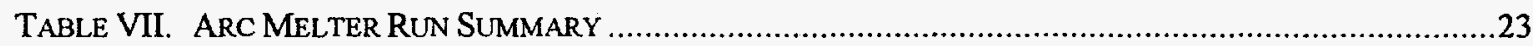

TABLE VIII PARTICULATE ANALYSIS RESULT SUMMARIZED FOR ALL RUNS .........................................41

\section{LIST OF FIGURES}

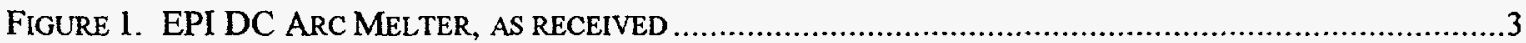

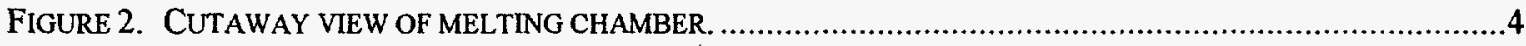

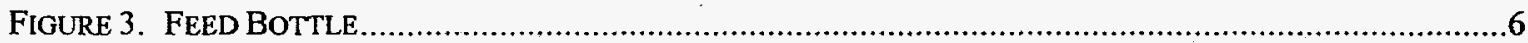

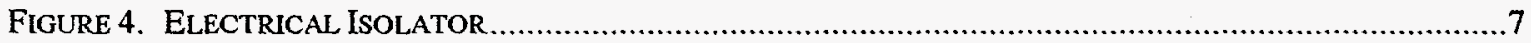

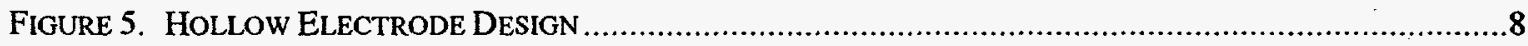

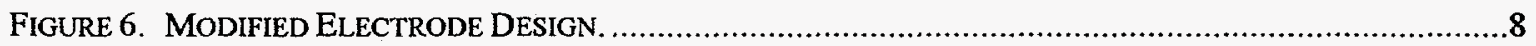

FIGURE 7. OFFGAS SYSTEM MODIFICATIONS MADE TO THE EPI MELTER FOR THIS STUDY $\ldots \ldots \ldots \ldots \ldots \ldots \ldots \ldots . . \ldots$

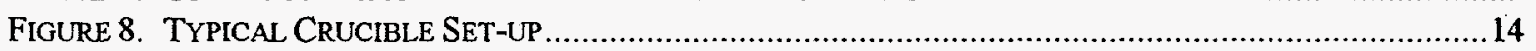

FIGURE 9. FLOW DIAGRAM FOR SAMPLE GAS CONDITIONING ....................................................... 17

FigURE 10. $\mathrm{CAO}_{1} \mathrm{AL}_{2} \mathrm{O}_{3}-\mathrm{SIO}_{2}$ PHASE DIAGRAM SHOWING COMPOSTTIONAL CHANGES ASSOCIATED WITH

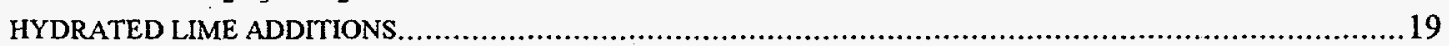

FIGURE 11. CAO- $\mathrm{B}_{2} \mathrm{O}_{3}-\mathrm{SIO}_{2}$ PHASE DIAGRAM SHOWING COMPOSITIONAL CHANGES ASSOCIATED WITH

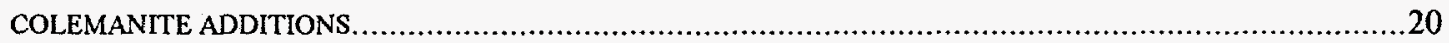

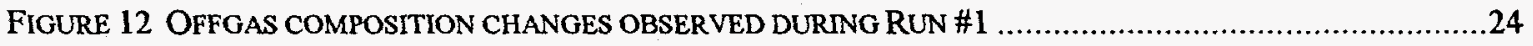

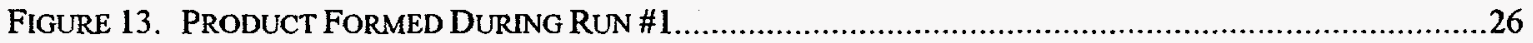

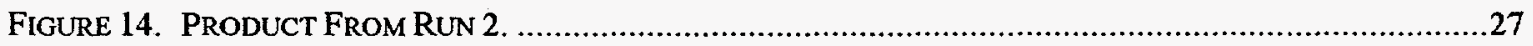

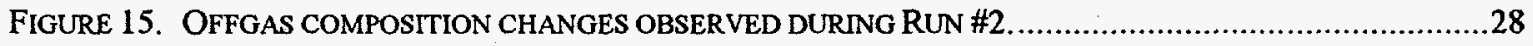

FIGURE 16. EXAMPLE OF ELECTRODE DAMAGE OCCURRING DURING AIR INJECTION...........................29

FIGURE 17. OFFGAS COMPOSITION CHANGES OBSERVED DURING RUN \#3 ............................................30

Figure 18. DAMAGE EXPERIENCED BY THE MOdIFIED ElECTRODE CAUSED BY AIR INJECTEd INTO THE

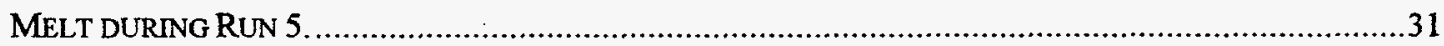

FIGURE 19. OFFGAS COMPOSITION CHANGES OBSERVED DURING RUN \#4 …........................................32

FIGURE 20. OFFGAS COMPOSITION CHANGES OBSERVED DURING RUN

FIGURE 21. HOMOGENEOUS GLASSY PRODUCT PRODUCED DURING RUN 6 ............................................35

FIGURE 22. OFFGAS COMPOSITION CHANGES OBSERVED DURING RUN \#6..........................................36

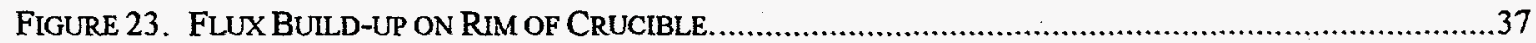

FIgURE 24. OFFGAS COMPOSITION CHANGES OBSERVED DURING RUN \#7 ..........................................39

FIGURE 25. PLACEMENT OF DEBRIS FOR RUN 8. NOTE THAT ACCESS TO THE BOTTOM ELECTRODE IS

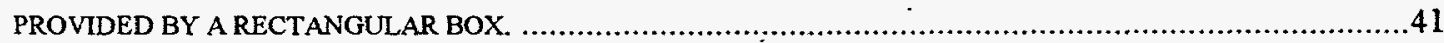

FIGURE 26. OFFGAS COMPOSITION CHANGES OBSERVED DURING RUN \#8 .......................................42 
Run 4 (ID \#017)

Run 5 (ID \#018)

Run 6 (ID \#020)

$-35$

Run 7 (ID \#021)

$-38$

Run 8 (ID \#022)

Particulate analysis

Electrode Consumption $-44$

CONCLUSIONS

RECOMMENDATIONS -

ACKNOWLEDGMENTS -..-15

RECORDS -

APPENDIX A -

Feed Compositions

APPENDIX B $-49$

Electrode Consumption $-49$

APPENDIX C 52

Permanent Gas Analysis Results (Runs 1-8) $\mathbf{5 2}$ 


\author{
FINAL REPORT \\ ON \\ HIGH TEMPERATURE VITRIFICATION FORMULATION \\ DEMONSTRATION FOR SRS CONTAMINATED SOHS
}

\title{
EXECUTIVE SUMMARY
}

This study was undertaken to demonstrate the application of a DC arc melter to in-situ vitrification of SRS soils. The melter that was available at the DOE/Industrial Vitrification Laboratory at Clemson University was equipped with opposing solid electrodes. To simulate field conditions, two hollow electrode configurations were evaluated which allowed fluxes to be injected into the melter while the soils were being vitrified. The first 4 runs utilized pre-blended flux (two runs) and attempted flux injection (two runs). These runs were terminated prematurely due to offgas sampling problems and melt freezing. The remaining four runs utilized a different electrode geometry, and the runs were not interrupted to change out the offgas sampling apparatus. These runs were conducted successfully.

Three fluxes were evaluated in this study; colemanite, dolomitic lime and hydrated lime. Colemanite did not sufficiently decrease the viscosity of the melt and was not used successfully in this study. Conversely, both dolomitic and hydrated lime promoted fluidity of the soil and formation of glassy waste products. Because of its relatively coarse particle size, the dolomitic lime was not fed successfully through the feeder that was devised and built at Clemson University. The hydrated lime fed well.

Analysis of the offgas streams revealed very high particulate content and very low $\mathrm{O}_{2}$ content. The high particulate content is attributed to a combination of melt agitation caused by the electric arc, and by highly reducing conditions at the melt surface caused by use of graphite electrodes. Despite the presence of reducing conditions, the processed soil products formed appeared to be glassy with little or no visible crystalline phases.

No accurate estimate of operating costs could be made during this study because of the limited size and batch mode of operation. Subsequent to these tests, an additional modification was made to the melter which allowed feeding an additional $25 \mathrm{~kg}$ of soil into the melter during operation. This doubled the batch size, with no additional power input, and caused the mode of energy input to change from the transferred arc mode to a joule heating mode as the ends of both electrodes became submerged in the melt. The study conducted for DOE/WSRC revealed much useful information about the performance of the DC arc melter. However, subsequent runs conducted by ESE students performing MS degree thesis research indicate that a great deal remains to be learned about more efficiently and effectively using this technology.

WSRC SC0003/TO 187 


\section{INTRODUCTION}

The Department of Energy is currently evaluating methods of treatment for disposal of hazardous and mixed wastes. Preferred methods of treatment include those technologies that are capable of consistently producing a durable, leach resistant product, while simultaneously minimizing disposal volumes. The selected technology must be demonstrated over a range of waste characteristics, including compositions, chemistries, moistures, and physical characteristics.

Vitrification has been selected as a technology that is capable of producing a highly durable product, while minimizing disposal volumes through organic destruction, moisture evaporation, and porosity reduction. In this study in-situ vitrification of soil using a graphite electrode DC arc melter was simulated. $25 \mathrm{~kg}$ batches of soil were charged into the melter's graphite crucible and the response of these batches to treatment by the melter was determined. To promote glass formation it was decided to operate the melter in the presence of air, and to introduce fluxing aides into the soil. Blending of the fluxes with the soil, while ensuring a uniform distribution of the flux, would not be representative of field operating conditions. The desired approach for making flux additions was injection through a hollow electrode while the melter was in operation. It was felt that this approach would come closest to simulating operation of a concentric electrode, nontransferred arc melter which, purportedly, would permit flux injection through the electrode. No such electrodes were available so Clemson University designed two geometries for evaluation. These electrodes were used to inject fluxes and air into the soil and the vitrification response of the soil was assessed.

\section{EXPERIMENTAL PROCEDURE}

\section{Description of the DC Arc Melter}

The Mark I-W DC Arc melter was designed by Electro-Pyrolysis, Inc., (EPI) of Wayne, PA. It was purchased by the Westinghouse Savannah River Company (WSRC) and installed at the DOE/Industrial Vitrification Laboratory at Clemson University. The Mark I-W water-cooled melter is the successor to the Mark I melter operated at the Massachusetts Institute of Technology. Promising results from the Mark I Melter prompted the fabrication and further testing with the Mark I-W.

The melter currently has the capability to process $1 \mathrm{ft}^{3}$ of feed in batch mode only. The Mark I-W DC arc melter, shown in Figure 1, is comprised of the following systems, which are described in more detail below.

- Furnace Assembly

- Electrode Assembly

- Offgas System

- Water Cooling System 
- Nitrogen Purge System

- Electrical Power Supply

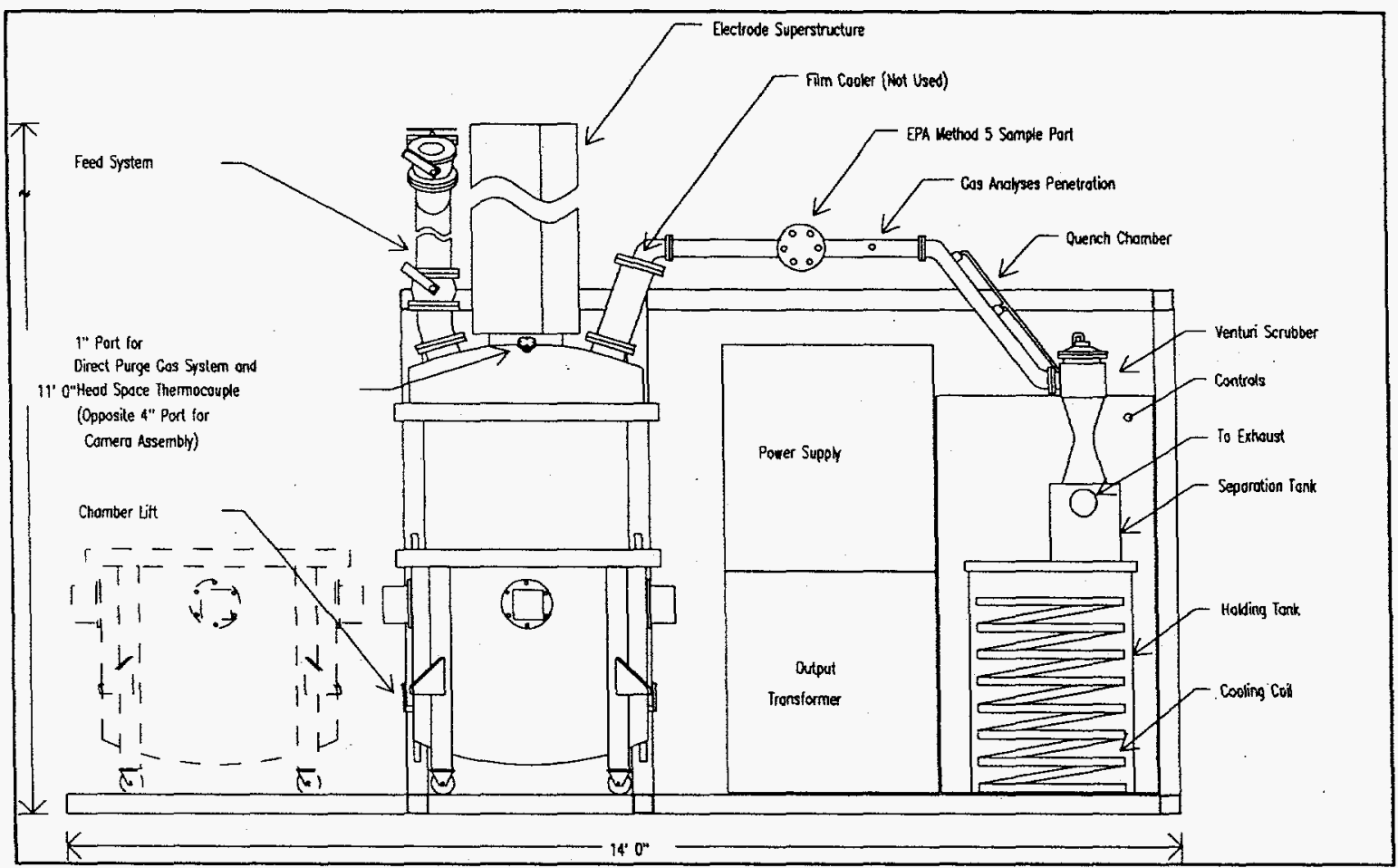

Figure 1. EPI DC Arc Melter, as received

\section{Furnace Assembly}

The Mark I-W furnace features a removable, stainless steel, lower chamber and a stainless steel, fixed upper roof. The lower chamber can be raised or lowered to mate with the roof by a screw-driven mechanism. When in the lowered position, the chamber can be rolled away from the fixed roof assembly. When the components are bolted together the combined height is $431 / 2$ inches with an OD of $371 / 2$ inches. Both the lower chamber and the roof have a water-cooled shell.

A cutaway view of the chamber section is shown in Figure 2. The lower chamber contains two nested graphite crucibles. The area between the outer crucible and the water-cooled shell is lined with fiberboard insulation and refractory bricks. Nitrogen is supplied through a dispersion tube at the bottom of the chamber. The outer graphite crucible is connected to the positive side of the power supply by graphite rods at four locations. The inner crucible rests in direct contact with the outer crucible and acts as the positive electrode for the melt. A graphite disk with a hole in the center is placed on the bottom of the inner crucible. This disk allows starting electrodes of various sizes to be placed inside the inner 
crucible. The graphite components and nitrogen purge promote a highly reducing atmosphere in the melter during operation.

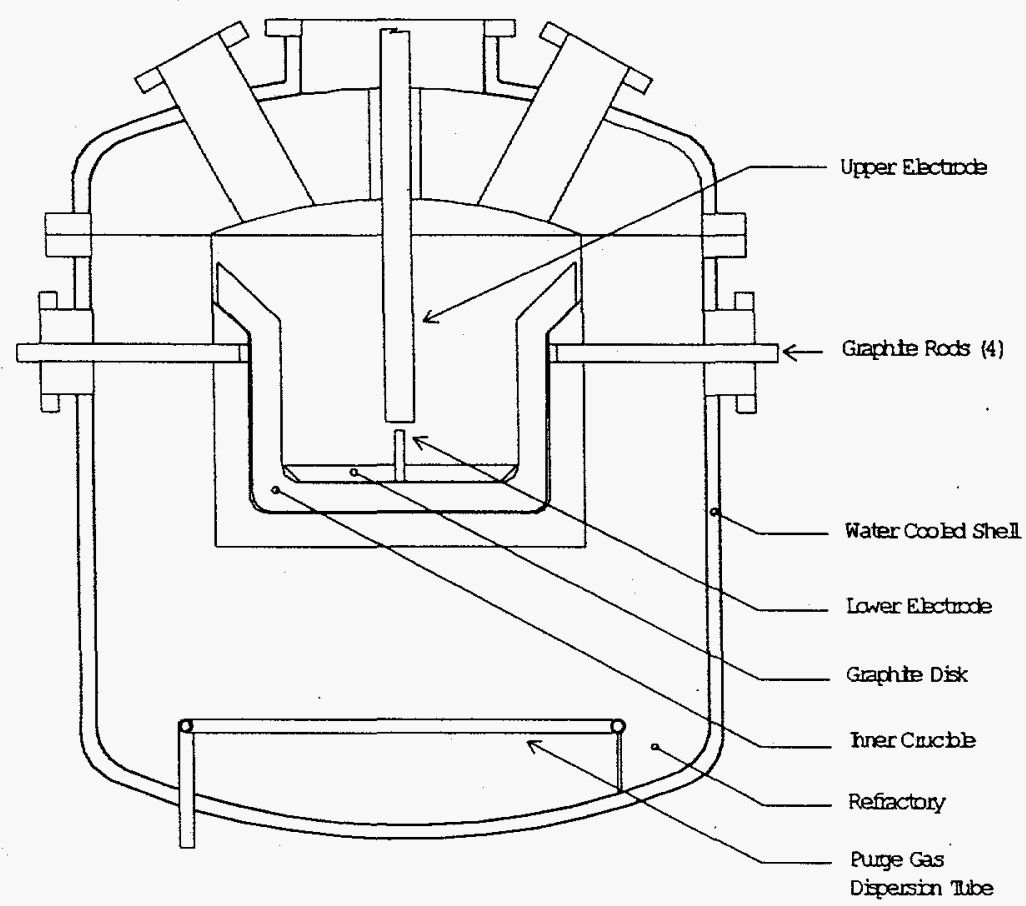

Figure 2. Cutaway view of melting chamber.

\section{Electrode Assembly}

The electrode superstructure houses the movable upper electrode and is mounted on top of the furnace roof. The movable upper electrode is mounted to the electrode carriage, which is raised and lowered by a screw-driven mechanism. The height of the electrode is measured by a position indicator. The superstructure is subject to a nitrogen purge during operation to keep oxygen out of the this superstructure. Negative voltage from the power supply is applied to the upper graphite electrode.

To create the arc, the movable upper electrode is lowered to contact the lower starter electrode. As current is passed through the electrodes, the upper electrode is raised and a DC plasma arc is initiated. The arc is sustained until the material is melted. Once the run is complete, the power is turned off and the melter is cooled. When a melt has cooled sufficiently, the inner crucible is lifted out and inverted to allow the contents to be removed.

\section{Offgas System}

The offgas system consists of the following major pieces of equipment: 
- Quench Chamber

- Induced Draft Blower

- Gas Flow Meter

Figure 1 shows the location of the major components of the offgas system as it was received. The nitrogen and gases evolved from processing the wastes exit the melt chamber through a 4" ID port through the chamber roof section. From there, the gases enter a cyclone where larger particulate matter is to be removed. Offgas then enters the quench chamber where it is cooled prior to entering a water-jet venturi scrubber. This scrubber uses a jet of water to induce a flow of gas through the venturi and provide water droplets for the collection of particles.

The scrubber is followed by a separation tank which separates the gases and the scrub water. The water supply to the scrubber flows into a polypropylene holding tank. Water is pumped from this tank, filtered, and returned to the scrubber.

The gases are then drawn through an explosion proof induced draft blower. The blower provides the additional suction to draw the gases through the equipment. Following the blower, the gases passes through a mass flow meter, and are exhausted to the atmosphere.

The offgas system was modified to accommodate sampling during the runs. These modifications are discussed later.

\section{Water Cooling System}

Many components of the Mark I-W furnace are water cooled:

- Lower Chamber Shell

- Upper Chamber Shell

- Lower Chamber Electrode Connections

- Power Supply Transformer

- Recirculation Tank

A total of $20 \mathrm{gpm}$ flow is used to keep the system cool.

\section{Nitrogen Purge System}

Nitrogen is typically used as a purge gas during the melt and cool-down periods. The reducing atmosphere promoted by the inert gas purge prolongs the life of the graphite electrodes and crucible as well as decreasing the volume of offgas that would be evolved under an oxidizing atmosphere. In the as-received system, nitrogen was introduced into the melter area through a dispersion tube at the bottom of the chamber and through the upper electrode housing.

\section{Electrical Power Supply}

The power supply was manufactured by the Halmar Robicon Group. In this supply, $480 \mathrm{~V}, 3$ phase, $60 \mathrm{~Hz}$ power is chopped and then transformed to $1000 \mathrm{~Hz}$ using power transistors. This high frequency power is then rectified and filtered to provide DC current. 
The power at $100 \%$ output is $133.3 \mathrm{~V}$ and $750 \mathrm{~A}$. The power supply is current controlled, and current is set with a manual potentiometer.

\section{Melter Operation}

After charging and closing the melter, it was purged with air at a flowrate of $\sim 6 \mathrm{scfm}$ through one of the ports in the melter lid. Subsequently, the electrodes were brought into contact and the melter preheated by maintaining the voltage and current at $\sim 10-15$ volts and $\sim 200$ amps $(\sim 2-3 \mathrm{~kW})$ for about 20 minutes. After preheating, the electrodes were separated and the power increased to $\sim 14 \mathrm{~kW}(35 \mathrm{~V}$ and $400 \mathrm{~A})$. It was attempted to maintain these operating conditions for the duration of the run.

Upon completion of the run, the melter was allowed to cool overnight. The crucible was removed from the melter the next day and the contents of the crucible were dumped from it.

\section{Equipment Modifications}

\section{Flux Feeder Design and Operation}

The flux feeding system consisted of a feed bottle used to fluidize the flux, a flexible stainless steel hose used to transport the fluidized flux, an electrical isolator through which the flexible hose entered the melter and a hollow electrode, described later, which transported the fluidized flux to the melt. The feed bottle was composed of a one gallon Nalgene Bottle with an air nozzle mounted in the bottom and a connection in the top to which the flexible hose was connected as shown in Figure 3.

The electrical isolator is shown in Figure 4. The flexible hose connected to a 0.65 inch hole in the side of the hollow electrode and was secured to the electrode with stainless steel wire. The portion of the flexible hose inside the headspace was wrapped with kaolinite wool fire blanket to

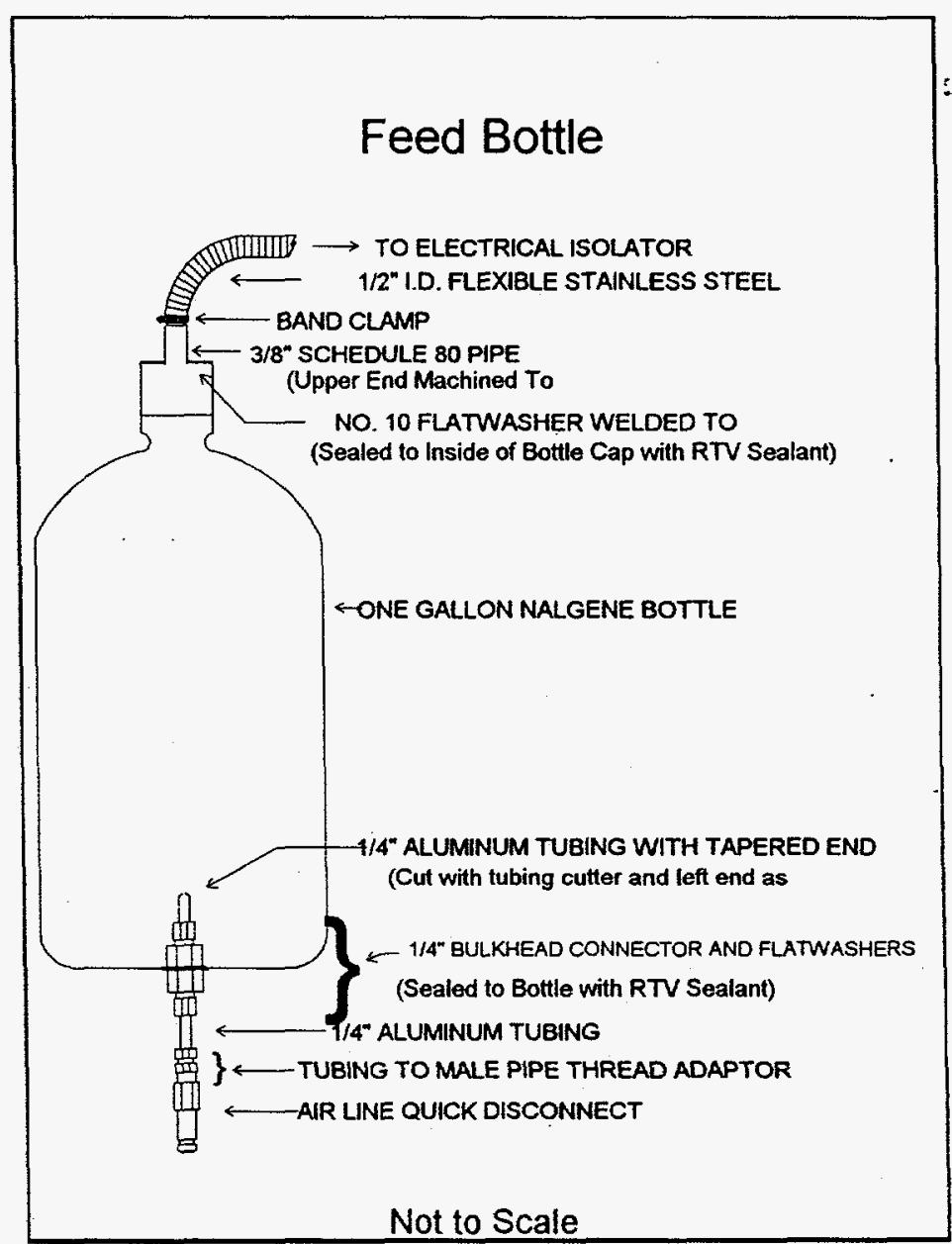

Figure 3. Feed Bottle 


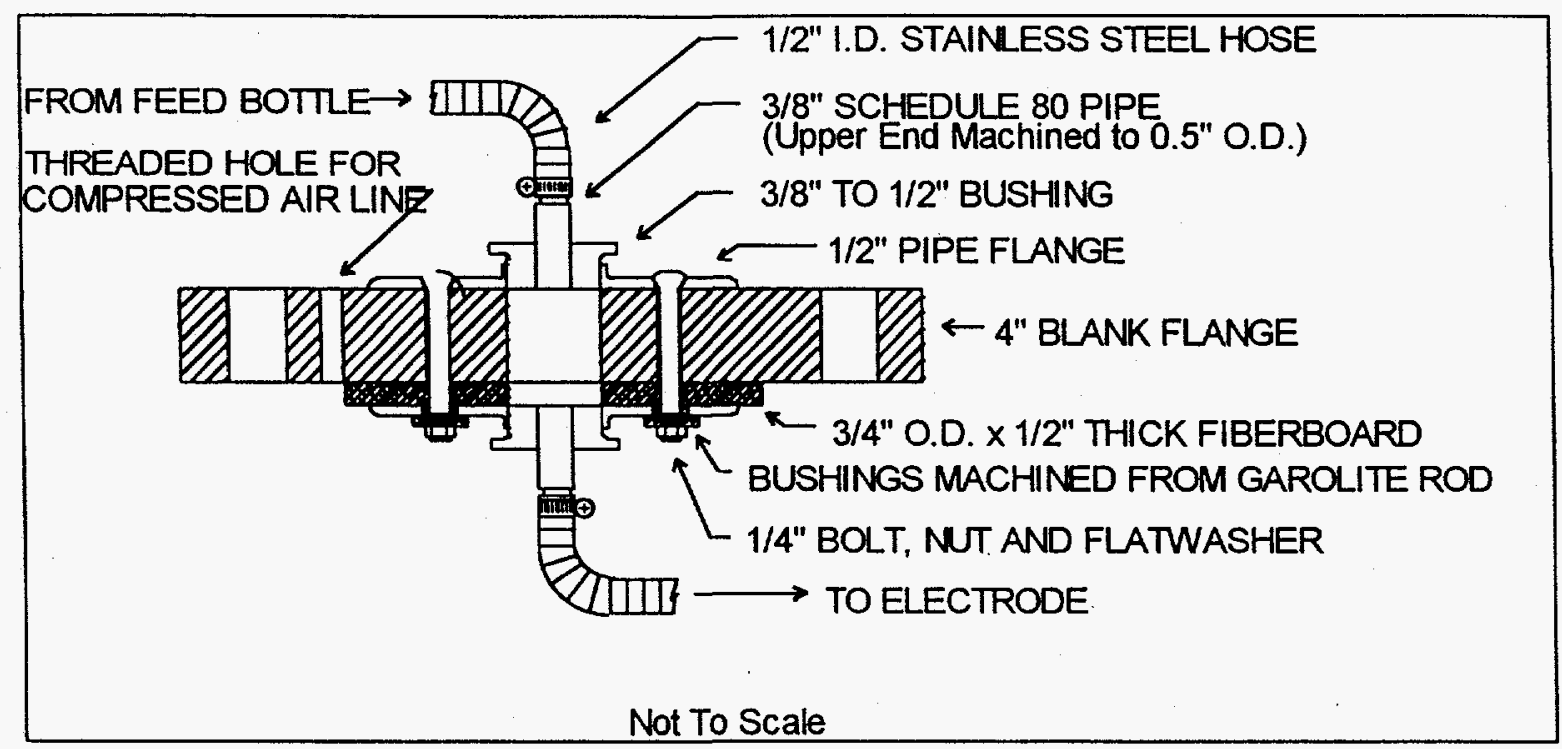

\section{Figure 4. Electrical Isolator}

provide protection from heat and molten splatter. A compressed air line with a 0-5 scfm flowmeter in-line was used to blow air into the feed bottle nozzle. Air flow rates of $1 / 2,1$, $1-1 / 2,2,3$ and $4 \mathrm{scfm}$ were tried. It was found that a flow of 1-1/2 scfm was sufficient to fluidize the flux and that higher flow rates were unnecessary. Starting with a bottle completely filled with flux, it took one to two minutes to feed approximately two-thirds of the flux. The last third of the bottle would not feed with the bottle upright since the flux level approached the top of the nozzle. The bottle was blown down to this level and then refilled. After the last refill, the flux remaining in the bottom of the bottle was fed by turning the bottle upside down several times and shaking. All of the flux was fed in by half of the total run time on runs 6,7 and 8 . 


\section{Hollow Electrode Design}

Demonstration of in-situ vitrification is not accurately modeled by preblending fluxes and soil. In these studies it was desired to inject the flux at the arc location through a hollow electrode. Since this melter had not been previously operated with a hollow electrode, and none were available for this use, two concepts were developed by Clemson University and tested during this project.

The hollow electrodes used for feeding flux were UCAR grade CS extruded graphite machined to three inches in diameter. The hollow electrodes used in runs 2 and 3 (the second and third experimental runs in this project) had a one inch hole bored down the center through which air and flux was blown.

See Figure 5 for details of this electrode design. This design was modified for runs 4 through 8 to allow air and flux to exit
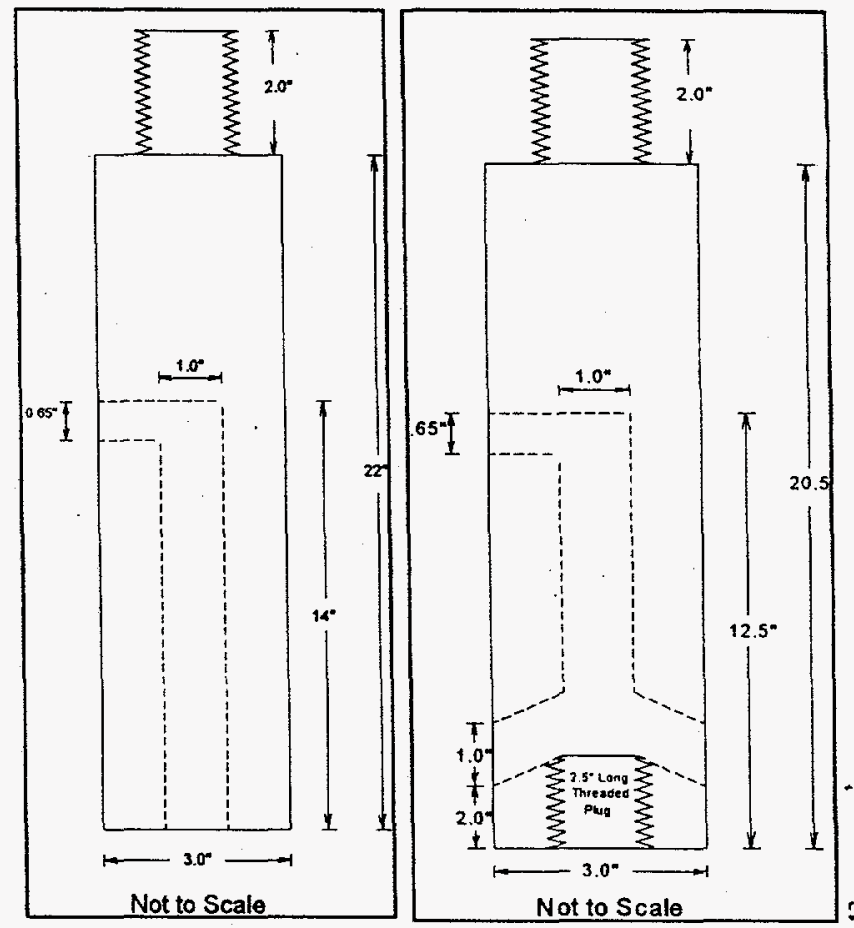

Figure 5. Hollow Electrode Design
Figure 6. Modified Electrode Design. from the sides of the electrode rather than from the bottom. The center hole was plugged and a pair of one inch holes were drilled in the sides of the electrode as shown in Figure 6. The holes were drilled at an angle to guide the air and flux toward the melt and to prevent flux from accumulating inside the electrode. The electrodes were also shortened by $1-1 / 2$ inches. The flexible hose installed in the 0.65 inch hole limits the upward travel of the electrode. Reducing the distance from the 0.65 inch hole to the bottom of the electrode allowed more electrode travel, which gives greater flexibility in controlling the arc.

\section{Off-gas System Changes}

The off-gas system was modified by removing the cyclone and installing sample ports for EPA method 5 and gas chromatograph sampling. The cyclone was ineffective due to the low flow rates in the off-gas system. Details of the off-gas modifications are shown in Figure 7. 


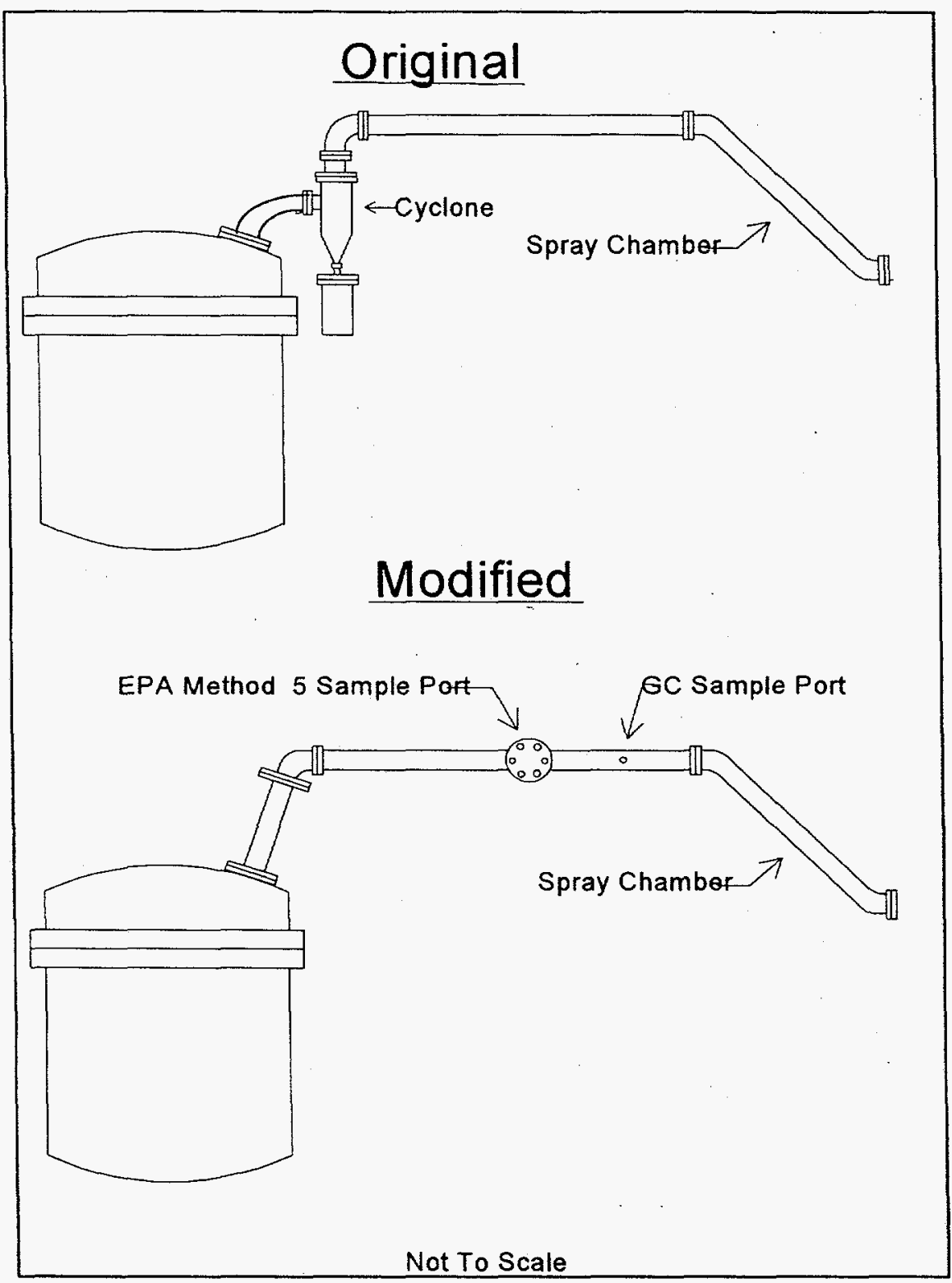

Figure 7. Offgas system modifications made to the EPI melter for this study.

\section{Purge Gas System Modifications}

A compressed air line with a 0-6 scfm flowmeter in-line was connected to a threaded hole in the 4" blank flange adjacent to the electrical isolator to allow the addition of air into the headspace. See Figure 4. 


\section{Video Camera}

A water-cooled Combustion Tec lens assembly two foot in length passes through the chamber roof and records the arc vitrification process by means of a color video camera equipped with filters to decrease the intensity of the light.

\section{Description of the Soils}

Two Savannah River Site soil types were used in this project; a sandy soil and a clay soil. The compositions investigated in this study were the sandy soil and a 50:50 mix of the clay and sandy soils. The compositions of the two soils types are shown in Table I.

Table I Normalized SRS Clay and Sandy Soil Compositions

Values are in Weight \% (ADS \#67186\&67187)

\begin{tabular}{|c|c|c|}
\hline Oxide & Clay Soil & Sandy Soil \\
\hline $\mathbf{A l}_{2} \mathbf{O}_{3}$ & 4.310 & 0.733 \\
\hline $\mathbf{B}_{2} \mathbf{O}_{3}$ & 0.014 & 0.014 \\
\hline $\mathbf{B a O}$ & 0.006 & 0.006 \\
\hline $\mathrm{CaO}$ & 0.094 & 0.021 \\
\hline $\mathrm{CdO}$ & 0.006 & 0.006 \\
\hline $\mathrm{Cr}_{2} \mathrm{O}_{3}$ & 0.016 & 0.015 \\
\hline $\mathrm{Fe}_{2} \mathrm{O}_{3}$ & 1.730 & 0.580 \\
\hline $\mathbf{L a O}$ & 0.004 & 0.004 \\
\hline MgO & 0.014 & 0.002 \\
\hline $\mathrm{MnO}$ & 0.004 & 0.004 \\
\hline $\mathrm{Na}_{2} \mathrm{O}$ & 0.342 & 0.337 \\
\hline $\mathrm{NiO}$ & 0.034 & 0.034 \\
\hline $\mathbf{P}_{2} \mathbf{O}_{5}$ & 0.077 & 0.060 \\
\hline $\mathbf{P b O}$ & 0.035 & 0.034 \\
\hline $\mathrm{SiO}_{2}$ & 93.017 & 97.977 \\
\hline SrO & 0.003 & 0.003 \\
\hline $\mathrm{TiO}_{2}$ & 0.236 & 0.147 \\
\hline $\mathrm{ZnO}$ & 0.004 & 0.004 \\
\hline $\mathrm{ZrO}_{2}$ & 0.056 & 0.020 \\
\hline Total & 100.000 & 100.000 \\
\hline
\end{tabular}

\section{Crucible Studies}

\section{Crucible Study Run Plan}

The crucible study investigated the effects of 3 different flux types on the two SRS soils (clay and sandy). In this study the clay soil contained $93 \% \mathrm{SiO}_{2}$ and the sandy soil contained $98 \% \mathrm{SiO}_{2}$, with the remaining component being primarily $\mathrm{Al}_{2} \mathrm{O}_{3}$. Based on 
these soil compositions, the WSRC Task Order Representative selected the $\mathrm{CaO}-\mathrm{Al}_{2} \mathrm{O}_{3}$ $\mathrm{SiO}_{2}$ system for investigation, with the $\mathrm{Ca}$ to be added as the flux.

The three fluxes considered were (1) hydrated lime $\left[\mathrm{Ca}(\mathrm{OH})_{2}\right],(2)$ dolomitic, or pelletized, lime (a Ca-Mg compound) and (3) colemanite. Colemanite is a naturally occurring mineral comprised mainly of $\mathrm{B}_{2} \mathrm{O}_{3}$ and $\left.\mathrm{CaO}\left[(\mathrm{CaO})_{2}\left(\mathrm{~B}_{2} \mathrm{O}_{3}\right)_{3} \cdot 5 \mathrm{H}_{2} \mathrm{O}\right)\right]$. In addition to its $\mathrm{CaO}$ content, colemanite was of interest because of boron's ability to capture neutrons liberated during radioactive decay.

The crucibles used for this study were B\&B Refractors \#6 assay crucibles. These are an alumina-silicate composition which have very good thermal shock resistance and a temperature rating of $1700^{\circ} \mathrm{C}$ for their intended use. Experimentation has shown a life expectancy of between four and six hours at temperatures between 1400 and $1600^{\circ} \mathrm{C}$ when used in glass studies of the $\mathrm{CaO}-\mathrm{Al}_{2} \mathrm{O}_{3}-\mathrm{SiO}_{2}$ ternary system.

The crucible study consisted of 23 trials, 16 selected initially and an additional 7 added to clarify some issues that arose during the originally planned trials. These trials included the two soils and flux additions ranging from $5 \%$ to $35 \%$. Table II identifies the actual variations evaluated.

LOD's and LOI's were determined for each of the soils and fluxes to account for losses of water and $\mathrm{CO}_{2}$, and transformations to the stable oxide phase. Oxide-basis calculations were then made and the appropriate amounts of each constituent were mixed to prepare the crucible study batches. LOD/LOI results, calculated batch chemistries and amounts weighed are shown in Table III.

The prepared batches were placed in crucibles which were then placed in the Deltech bottom loading furnace at a temperature of $1550^{\circ} \mathrm{C}$. This temperature was chosen based on the combination of furnace capability, crucible life expectancy, and temperatures on the respective phase diagrams in the regions of interest. After stabilizing at $1550^{\circ} \mathrm{C}$, the crucible remained in the furnace for 3.5 hours. At the end of the 3.5 hour hold, the melt was visually examined for fluidity. Then the crucible was cooled at a rate of $2^{\circ} \mathrm{C} /$ minute. While in-situ cooling of the soil might be expected to occur at a slower rate, the $2^{\circ} \mathrm{C}$ /minute rate was chosen because it more closely simulated the cooling rate of the EPI melter and was expected to be slow enough to allow devitrification of unstable glasses. 
Table II. Crucible Study Experimental Matrix.

\begin{tabular}{|c|c|c|c|}
\hline \multicolumn{2}{|c|}{ Clay Soil } & & \\
\hline Weight \% Flux & Colemanite & Hydrated Lime & Dolomitic Lime \\
\hline \hline 5 & $\checkmark$ & $\checkmark$ & \\
\hline 10 & $\checkmark$ & $\checkmark$ & \\
\hline 15 & $\checkmark$ & $\checkmark$ & \\
\hline 20 & $\checkmark$ & $\checkmark$ & \\
\hline 30 & $\checkmark$ & & \\
\hline \hline Sandy Soil & & Hydrated Lime & Dolomitic Lime \\
\hline Weight \% Flux & Colemanite & $\checkmark$ & \\
\hline 5 & $\checkmark$ & $\checkmark$ & \\
\hline 10 & $\checkmark$ & $\checkmark$ & \\
\hline 15 & $\checkmark$ & $\checkmark$ & \\
\hline 20 & $\checkmark$ & $\checkmark$ & \\
\hline 25 & & $\checkmark$ & $\checkmark$ \\
\hline 30 & & $\checkmark$ & $\checkmark$ \\
\hline 35 & & & \\
\hline
\end{tabular}

When the Deltech reached a temperature of $1100^{\circ} \mathrm{C}$ during cooling, the crucible was quickly transferred to a Lindberg Blue-M furnace at the same temperature. The cool down cycle continued until a temperature of $100^{\circ} \mathrm{C}$ was reached. This interrupted cycle was used because a single furnace capable of performing the entire cycle was not available. The Deltech's elements are prone to embrittlement if cooled below $850^{\circ} \mathrm{C}$, and the Blue-M has an upper temperature limit of $1200^{\circ} \mathrm{C}$. The transfer also allowed the Deltech to be reheated and stabilized for the next run, while the cool-down cycle was being completed in the Blue-M. The total crucible study cycle, including the hold at $1550^{\circ} \mathrm{C}$ and the cool down to $100^{\circ} \mathrm{C}$, was approximately 15.6 hours, $\left(3.5\right.$ hours at $1550^{\circ} \mathrm{C}+12.1$ hours cooling).

After the crucible cooled, it was broken open and a visual observation was made to determine whether a glass or non-glassy phase had been made. Candidate compositions for processing in the arc melter were chosen based on the appearance of the phase formed. 
Table III. LOD/LOI results, calculated batch chemistries and amounts weighed

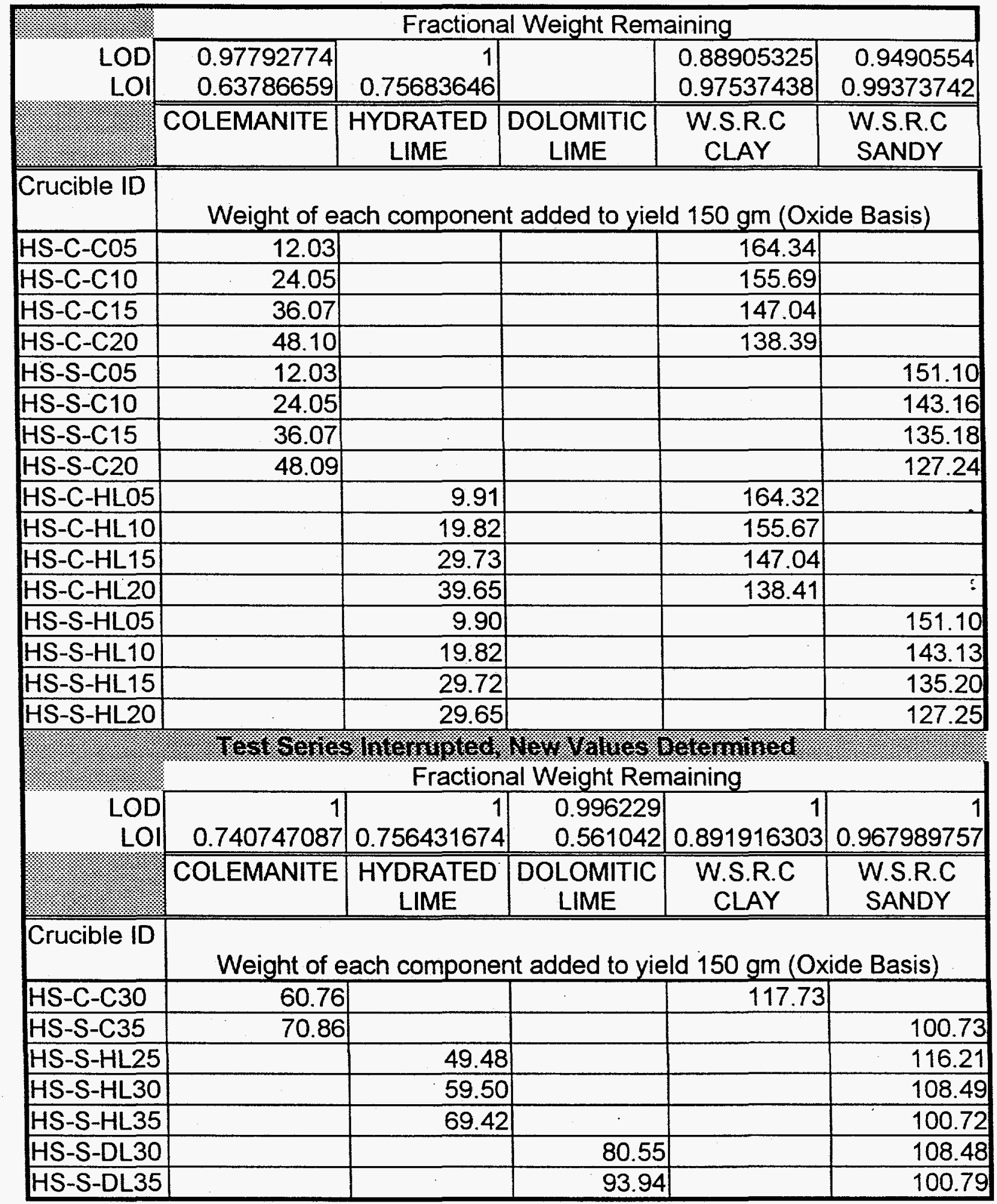




\section{Arc Melter Runs}

Arc melter runs were conducted according to the test matrix shown in Table IV. In all cases, the targeted product mass was $20 \mathrm{~kg}$. The total amount of feed charged into the crucible varied depending on LOD and LOI values. All of the batches contained $0.5 \%$ each of cerium and copper as surrogate radionuclide materials. Prior to charging the crucible, the lower electrode was shielded using a hollow tube. This prevented dirt from falling onto the lower electrode, but allowed passage of the upper electrode. Soil was then charged into the crucible. An example of this set-up is shown in Figure 8. The bottom electrode is shown in the center of the figure, protected by a tube made from grafoil. The outer, circularly arranged black platelets are grafoil sheets positioned to protect the upper chamfered portion of the crucible. Not visible in this figure is the grafoil liner between the soil and the crucible wall.

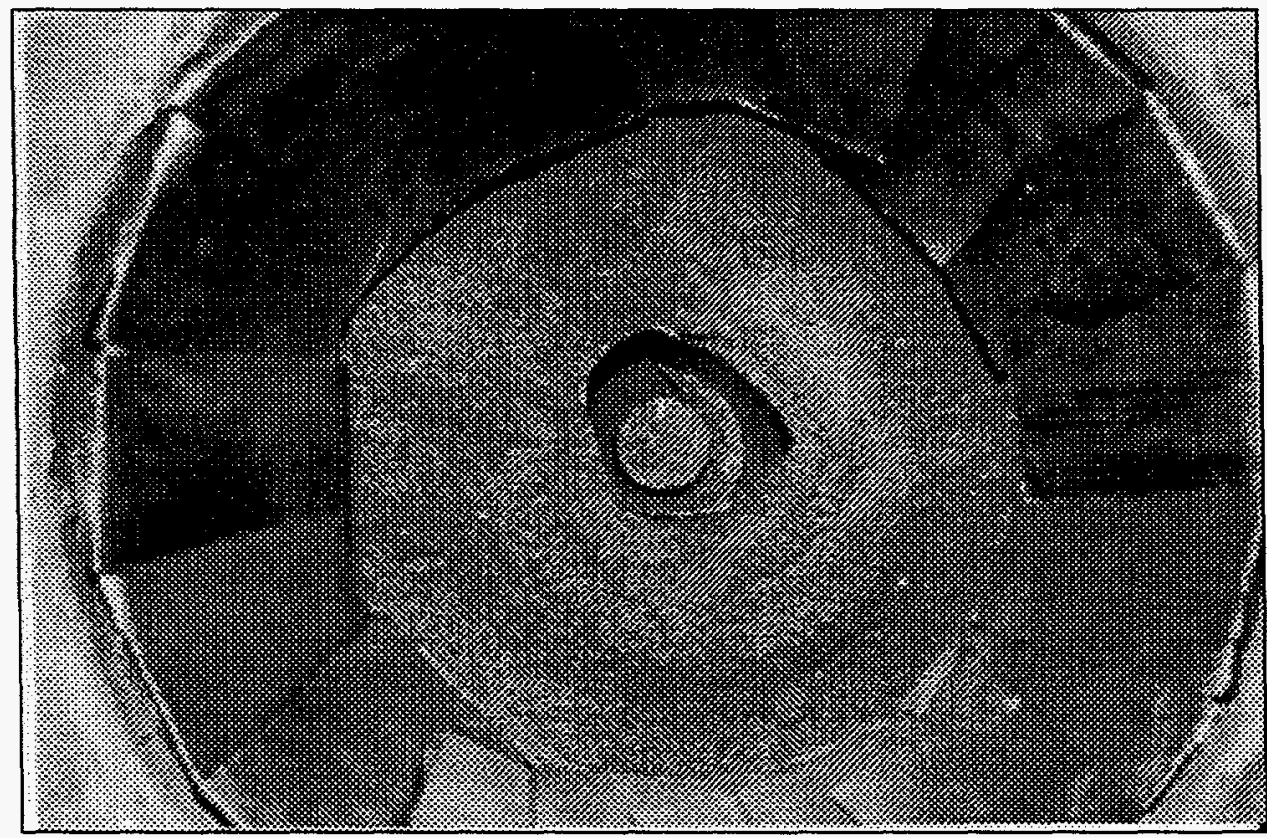

Figure 8. Typical Crucible Set-up

To assist soil melting, a small blend containing flux and soil was prepared and placed around the base of the bottom electrode. This was done to promote formation of a molten glass pool early in the run, thereby minimizing the chance of the arc damaging the graphite crucible.

Runs were conducted by flowing air at $5 \mathrm{scfm}$ into the headspace of the melter for 10 minutes prior to applying power to the electrodes. After the 10 minute purge, a low level of power was applied to allow heat-up of the electrodes. During this time, the analytical equipment used to record the progress of the run was given a final check. Finally, after an additional 10 minutes the arc was struck and the run was begun. 

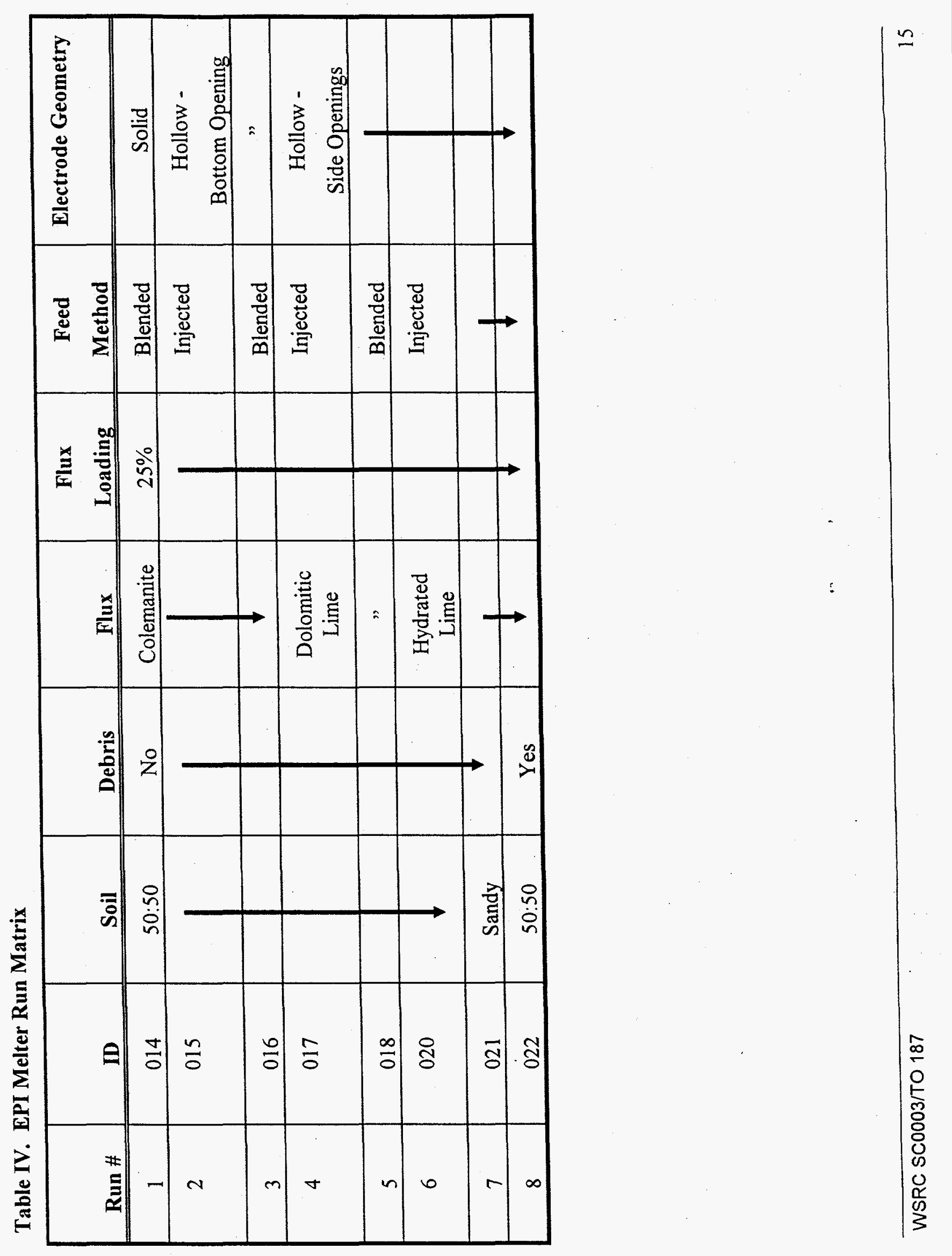


\section{Data Acquisition}

\section{Gas Analyses}

\section{Sample Gas Conditioning}

Figure 9 shows the flow diagram for conditioning the sample gases. In this system, a continuous gas sample is passed through a mini-cyclone and two filters to remove particulate matter. The primary filter is configured in a parallel arrangement with an identical filter. This allows the primary filter to be changed during sampling without disrupting continuous sampling and measurement. The secondary filter is a back-up to the primary filter. Shake-down experiments have not resulted in the collection of particulate matter on the secondary filter.

The offgases are drawn through the particulate matter controls by a vacuum pump. The vacuum pump then passes the gas sample into a Genie membrane filter to remove moisture. Moisture is further removed by a Perma-Pure co-axial drying tube. The gases to be sampled are passed through the inner shell of the Perma-Pure drier while warm, dry nitrogen is passed countercurrent to the gas sample through the outer shell. The inner and outer shells are separated by a naphion membrane which allows moisture in the gas sample to be collected by the warm, dry nitrogen. As a last precaution the gas sample is passed through a 0.5 micron filter before being introduced into the analytical instruments.

\section{Gas Chromatograph Analysis}

A steady, representative sample of the offgases was introduced into a MTITM M200 gas chromatograph. Data acquisition is obtained using MTITM's EZ Chrome 200 v. 3.5.8 software. The gas chromatograph is capable of continuous on-line sampling, configured to cycle every $2 \frac{1}{2}$ minutes. The characteristics of the gas chromatograph are shown in Table V.

The gas chromatograph is capable of measuring all of these gases in any range, as long as the gas chomatograph is calibrated within the expected range of measurement. Previous experience with the gas chromatograph applied to the offgas from the $\mathrm{DC}$ arc melter indicates only $\mathrm{H}_{2}, \mathrm{O}_{2}, \mathrm{~N}_{2}, \mathrm{CO}, \mathrm{CO}_{2}$, and $\mathrm{CH}_{4}$ are detectable with this particular instrument.

\section{EPA Method 5 Sampling}

Off-gases were sampled starting at the beginning of each run for particulate matter and moisture content using a sampling scheme based on EPA Reference Method 5 ( 40 CFR 60 ). An off-gas sample was drawn through a $1 / 2$ " stainless steel sample probe at approximately isokinetic conditions, then through a heated probe assembly, into a heated 
glass fiber filter and finally through a series of ice cooled impingers. The first impinger was an empty, modified Greenburg-Smith (straight center tube and no impinger plate).

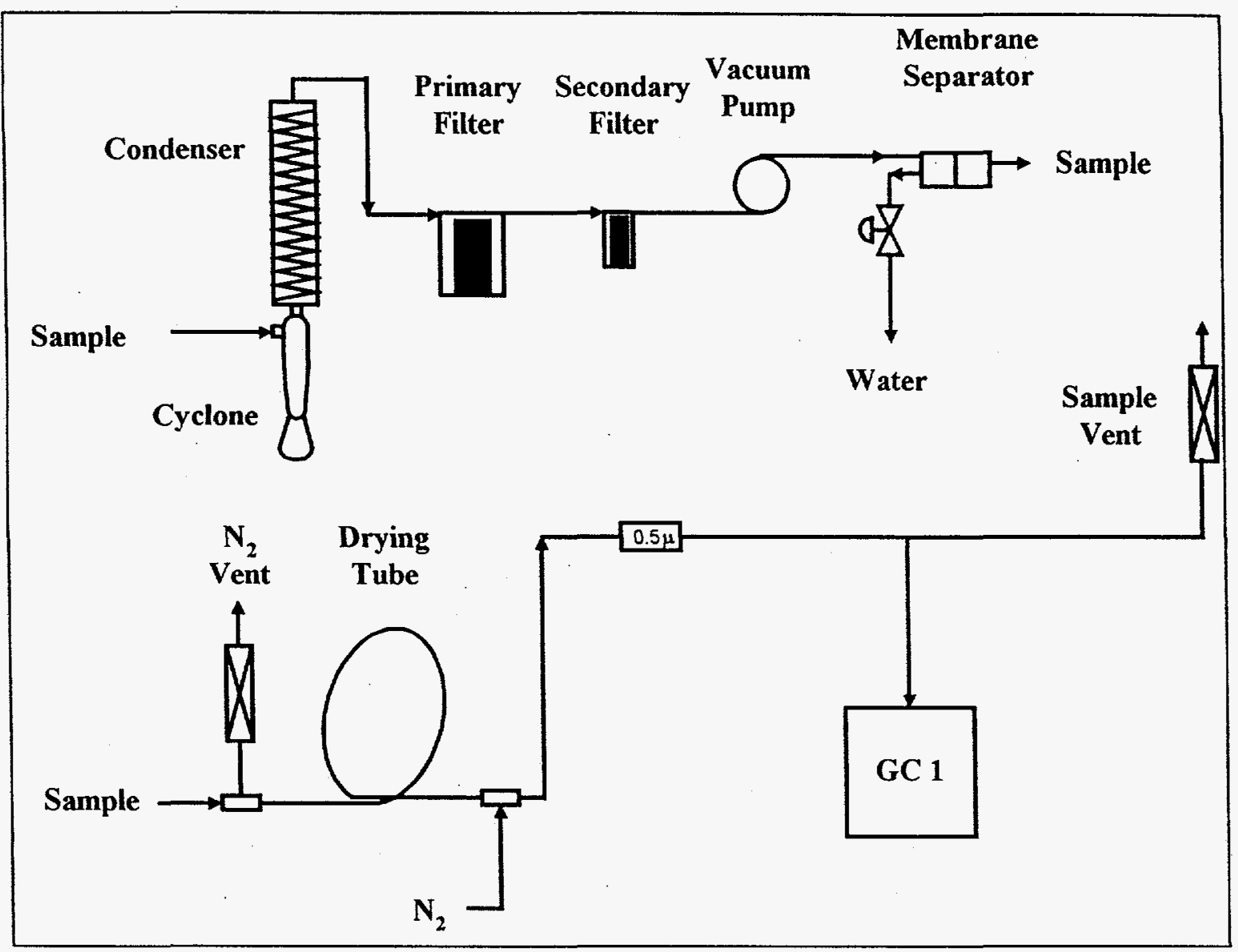

Figure 9. Flow Diagram for Sample Gas Conditioning

Table V Characteristics of gas chromatograph.

\begin{tabular}{|ll|}
\hline Column A & Column B \\
\hline Molecular Sieve 5A & HeySep R (HSR) \\
(MS5A) & \\
$\mathrm{H}_{2}$ - Hydrogen & $\mathrm{O}_{2} / \mathrm{N}_{2}$ - Air Composite \\
$\mathrm{O}_{2}$ - Oxygen & $\mathrm{CH}_{4}$ - Methane \\
$\mathrm{N}_{2}$ - Nitrogen & $\mathrm{CO}_{2}-$ Carbon Dioxide \\
$\mathrm{CH}_{4}$ - Methane & $\mathrm{C}_{2} \mathrm{H}_{6}$ - Ethane \\
CO - Carbon Monoxide & $\mathrm{C}_{3} \mathrm{H}_{6}$ - Propane \\
Carrier Gas - Argon & Carrier Gas - Helium \\
\hline
\end{tabular}


The second impinger was a modified Greenburg-Smith containing $100 \mathrm{ml}$ of distilled water. The third impinger was a standard Greenburg-Smith (tapered tip and impinger plate) containing $100 \mathrm{ml}$ of distilled water. The final impinger was a modified GreenburgSmith containing 200-300 g of silica gel.

\section{RESULTS and DISCUSSION}

\section{Crucible Studies}

Crucibles containing the soil and flux combination of interest were placed in the kiln at $1550^{\circ} \mathrm{C}$, allowed to remain at temperature for 3.5 hours and then cooled at $2^{\circ} \mathrm{C} / \mathrm{min}$ to $1100^{\circ} \mathrm{C}$. At this time the crucible was transferred to a lower temperature kiln, where the same cooling rate was continued down to $100^{\circ} \mathrm{C}$. The following coding designation was used to differentiate between the various samples.

\section{HS-x-yyzz;}

- where HS indicates the humid soils project,

- $\quad \mathrm{x}$ indicates soil type, $(\mathrm{S}=$ sandy or $\mathrm{C}=$ clay $)$

- yy is flux type, $(\mathrm{C}=$ colemanite, $\mathrm{HL}=$ hydrated lime, or $\mathrm{DL}=$ dolomitic lime $)$, and

- $\mathrm{zz}$ is flux level (wt \% on an oxide basis

So, for example, the code HS-S-HL05 indicates $\underline{\text { Humid }}$ Soils-Sandy soil- $\underline{\text { Hydrated }} \underline{\text { Lime at }}$ $\underline{5} \%$.

Assuming that the contribution of other impurities can be ignored, the Savannah River soils and hydrated lime mixtures can be described by the $\mathrm{CaO}-\mathrm{Al}_{2} \mathrm{O}_{3}-\mathrm{SiO}_{2}$ phase diagram, shown in Figure 10. If colemanite $\left(\sim 50: 50 \mathrm{CaO}: \mathrm{B}_{2} \mathrm{O}_{3}\right)$ is the flux being considered, it is convenient to ignore the minor impact of the $\mathrm{Al}_{2} \mathrm{O}_{3}$ and use the $\mathrm{CaO}-\mathrm{B}_{2} \mathrm{O}_{3}-\mathrm{SiO}_{2}$ phase diagram to represent the soil-flux blends (Figure 11). Using this simplified approach, the soils processed using up to $20 \%$ hydrated lime as the flux would not be expected to show any melting at $1550^{\circ} \mathrm{C}$. Conversely, all of the compositions processed with colemanite would be expected to melt at $1550^{\circ} \mathrm{C}$.

The results obtained with flux additions up to $20 \%$ agreed reasonably well with the results predicted by the phase diagrams. The sandy soil, with its low $\mathrm{Al}_{2} \mathrm{O}_{3}$ content, showed no melting when hydrated lime was the flux. The only reaction which did occur was sintering of the soil in the crucibles.

The clay soil-hydrated lime mixtures showed evidence of melting with flux additions of $15 \%$ or more. This melting response may have been influenced by the presence of $\sim 2 \%$ iron in the soil. Even though melting occurred, some of the reaction product was nonvitreous and not sufficiently fluid to be poured. Consequently, it was decided to investigate higher flux loadings using the higher melting point sandy soil. 


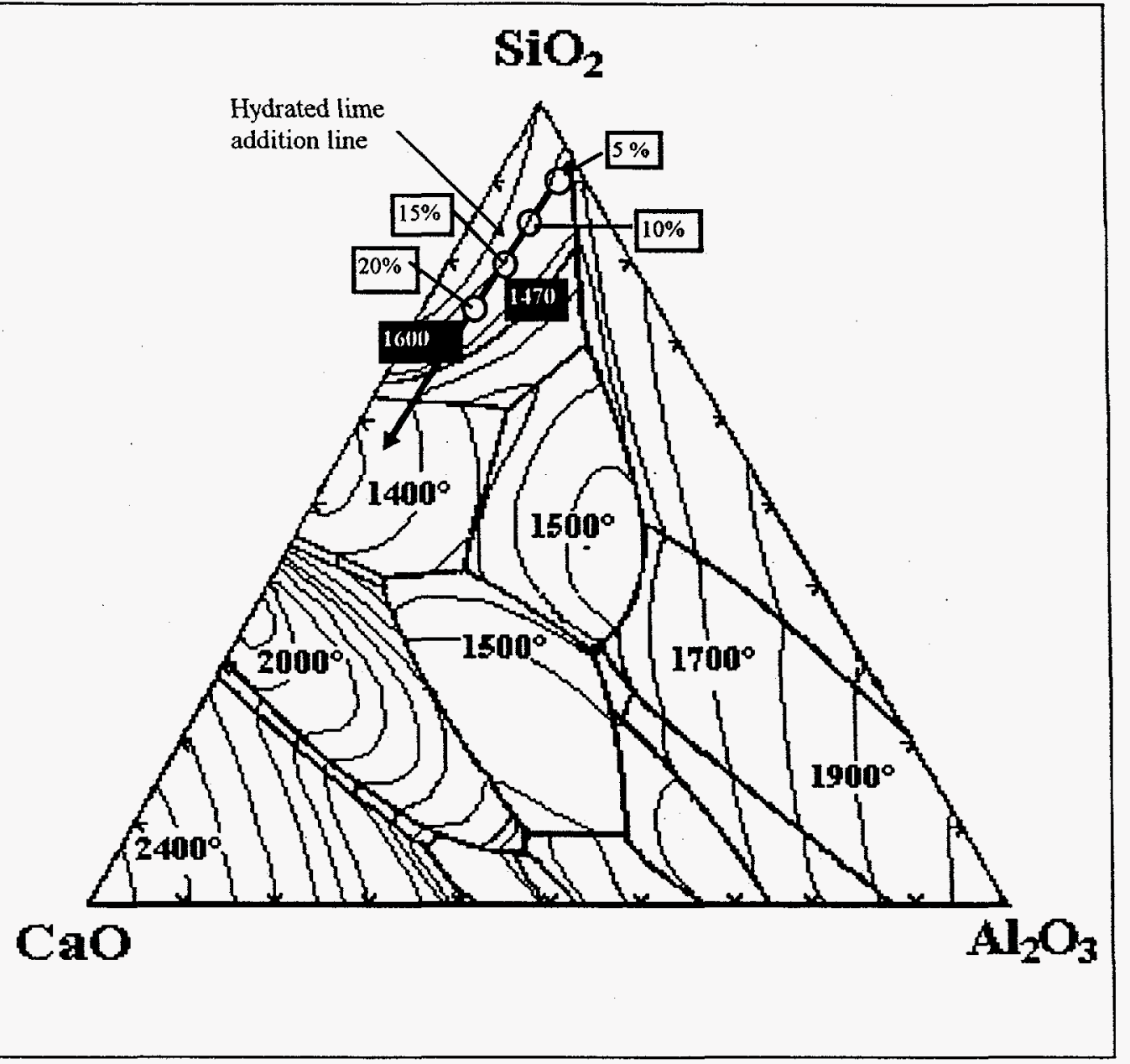

Figure 10. $\mathrm{CaO}-\mathrm{Al}_{2} \mathrm{O}_{3}-\mathrm{SiO}_{2}$ phase diagram showing compositional changes associated with hydrated lime additions.

Additional studies at 25,30 and $35 \%$ hydrated lime in sandy soil resulted in formation of a pourable fluid which formed a glass on cooling. At 25 and $30 \%$ hydrated lime the glass was a milky white color. At $35 \%$ hydrated lime, the glass took on a light blue tint as well.

In addition to hydrated lime, two crucibles of sandy soil were prepared with 30 and $35 \%$ dolomitic lime. In addition to $\mathrm{CaO}$, dolomitic lime contains $\sim 28 \% \mathrm{MgO}$. The dolomitic lime was evaluated because of its fine size, thereby making injection into the melt through the electrode easier than with the pelletized hydrated lime.

Both loadings of dolomitic lime created a fluid glass. However, a pellet of the $30 \%$ dolomitic lime glass was not poured because the crucible was destroyed and the glass leaked through a hole eaten through the crucible bottom.

The glass formed with $35 \%$ dolomitic lime was a milky white color tinted with blue. 
The crucible study results, summarized in Table VI, revealed that a flux loading of $<25 \%$ would not result in melting of soil at $1550^{\circ} \mathrm{C}$. Since the $\mathrm{DC}$ arc creates temperatures considerably greater than $1550^{\circ} \mathrm{C}$, a flux loading of $25 \%$ was believed to be adequate for soil processing.

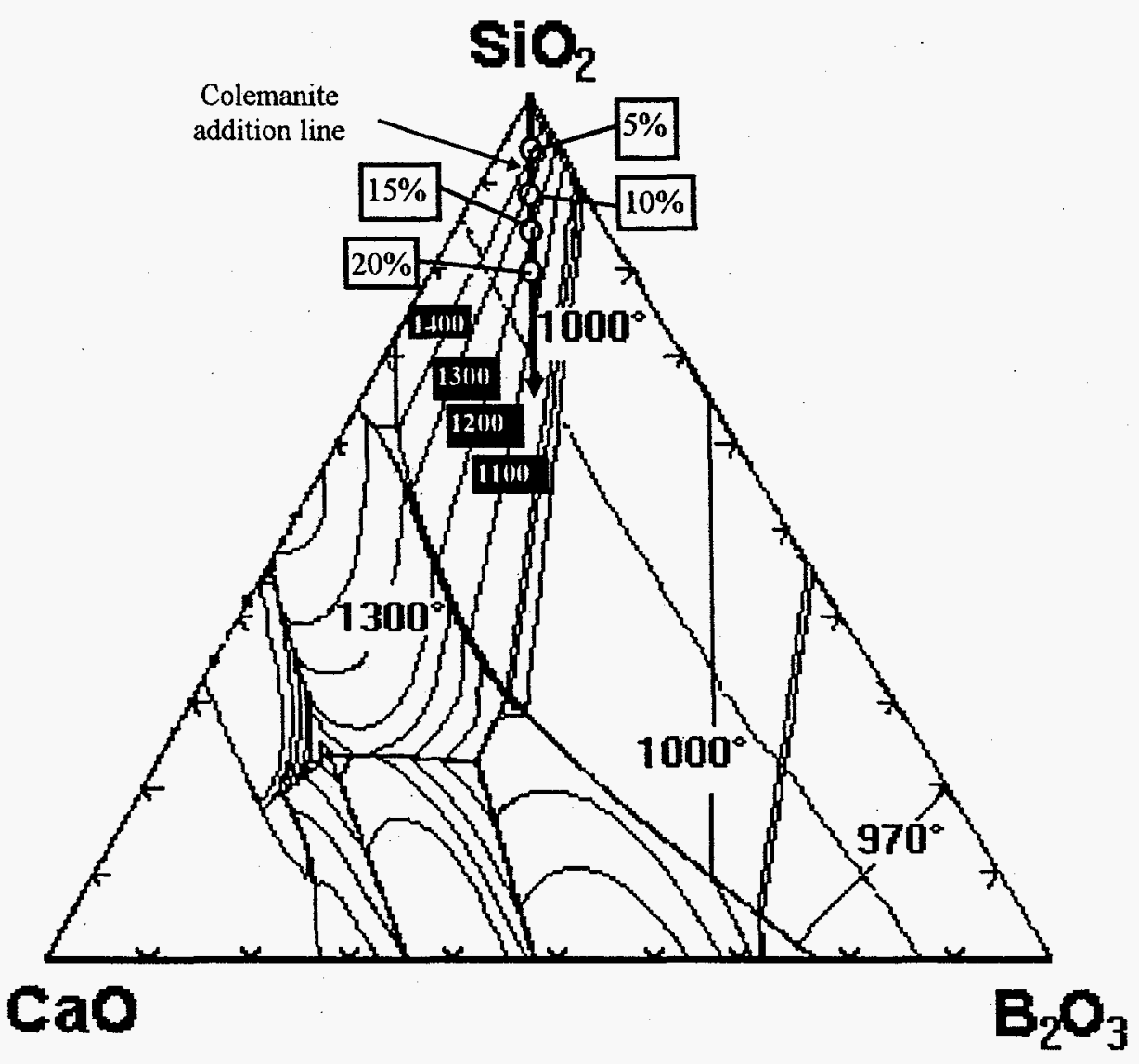

Figure 11. $\mathrm{CaO}-\mathrm{B}_{2} \mathrm{O}_{3}-\mathrm{SiO}_{2}$ phase diagram showing compositional changes associated with colemanite additions. 
Table VI. Crucible study results for the initial 16 scheduled trials:

(1550 $\mathrm{C} / 3.5$ hours)

\begin{tabular}{|c|c|}
\hline Batch & Results \\
\hline \multicolumn{2}{|r|}{ Clay soil-Colemanite flux } \\
\hline $\mathrm{HS}-\mathrm{C}-\mathrm{C} 05$ & Sintered soil \\
\hline $\mathrm{HS}-\mathrm{C}-\mathrm{ClO}$ & $\begin{array}{l}\text { Some opaque pale green glass with large unreacted layer } \\
\text { on top-trace of brown glass }\end{array}$ \\
\hline HS-C-C15 & $\begin{array}{l}\text { More opaque pale green glass with unreacted layer on top- } \\
\text { trace of brown glass }\end{array}$ \\
\hline $\mathrm{HS}-\mathrm{C}-\mathrm{C} 20$ & $\begin{array}{l}\text { Large amount of opaque green glass with smaller unreacted } \\
\text { layer on top-trace of brown glass }\end{array}$ \\
\hline $\mathrm{HS}-\mathrm{C}-\mathrm{C} 30$ & $\begin{array}{l}\text { Not pourable. Formed same opaque pale green glass as } \\
\text { earlier colemanite runs }\end{array}$ \\
\hline \multicolumn{2}{|r|}{ Sandy soil - Colemanite flux } \\
\hline HS-S-C05 & Sintered sand \\
\hline $\mathrm{HS}-\mathrm{S}-\mathrm{C} 10$ & Sintered sand \\
\hline HS-S-C15 & Sintered sand- some distinct opaque green glass phase \\
\hline HS-S-C20 & $\begin{array}{l}\text { Foamy green tinted white glass-ceramic- some distinct } \\
\text { opaque green glass phase }\end{array}$ \\
\hline HS-S-C35 & $\begin{array}{l}\text { Not pourable. Formed same opaque pale green glass as } \\
\text { earlier colemanite runs }\end{array}$ \\
\hline \multicolumn{2}{|r|}{ Clay soil - Hydrated lime flux } \\
\hline HS-C-HL05 & Sintered soil \\
\hline HS-C-HL10 & Sintered soil \\
\hline HS-C-HL 15 & Sintered soil/ceramic \\
\hline HS-C-HL20 & Pale green glass-ceramic \\
\hline \multicolumn{2}{|r|}{ Sandy soil - Hydrated lime flux } \\
\hline HS-S-HLO5 to HL20 & Sintered sand \\
\hline HS-S-HL25 & $\begin{array}{l}\text { Fluid, poured pellet, crucible contents and pellet both } \\
\text { formed milky white glass upon cooling }\end{array}$ \\
\hline HS-S-HL30 & $\begin{array}{l}\text { Fluid, poured pellet, crucible contents and pellet both } \\
\text { formed milky white glass upon cooling }\end{array}$ \\
\hline HS-S-HL35 & $\begin{array}{l}\text { Fluid, poured pellet, crucible contents and pellet both } \\
\text { formed milky white glass with a light blue tint upon cooling }\end{array}$ \\
\hline \multicolumn{2}{|r|}{ Sandy soil - Dolomitic lime flux } \\
\hline HS-S-DL30 & $\begin{array}{l}\text { Crucible was removed from kiln due to failure. A fluid glass } \\
\text { had formed, but ate a hole through the crucible bottom } \\
\text { resulting in loss of melt }\end{array}$ \\
\hline HS-S-DL35 & $\begin{array}{l}\text { Fluid, poured pellet, crucible contents and pellet both } \\
\text { formed heavily blue tinted milky white glass }\end{array}$ \\
\hline
\end{tabular}




\section{Arc Melter Runs}

Arc melter run results are summarized in Table VII. Additional details regarding compositions and electrode consumption are contained in Appendices A and B, respectively. The runs are discussed below.

\section{Run 1 (ID\# 014)}

The melter was charged with a preblended batch consisting of equal parts of sandy and clay-type soils ( $37 \mathrm{wt} \%$ each), $25 \%$ colemanite as the flux, and $0.5 \%$ each of $\mathrm{CuO}$ and $\mathrm{Ce}_{2} \mathrm{O}_{5}$. The total weight of the batch was $24.26 \mathrm{~kg}$, calculated to produce $20 \mathrm{~kg}$ of glass.

After charging and closing the melter, it was purged with air at a flowrate of $\sim 6 \mathrm{scfm}$ through one of the ports in the melter lid. The arc was established and the melter preheated by maintaining the voltage and current at $\sim 10-15$ volts and $\sim 200$ amps $(\sim 2-3$ $\mathrm{kW}$ ) for about 20 minutes. Subsequently, the electrodes were separated and the power increased to $\sim 14 \mathrm{~kW}$ ( $35 \mathrm{~V}$ and $400 \mathrm{~A}$ ). These operating conditions were maintained for approximately an additional 80 minutes (100 minutes cumulative run time) for a total power input of $29 \mathrm{kWh}$ as measured by a power meter on the melter.

As the power was increased, there was an immediate increase in $\mathrm{CO}_{2}$ emissions, coupled with a corresponding decrease in $\mathrm{O}_{2}$ present in the offgas, see Figure 12. Continuous monitoring of the offgas with a gas chromatograph showed that the $\mathrm{O}_{2}$ level decreased from an initial value of $\sim 21 \%$ to $<1 \%$ ninety-three minutes into the run. At the same time, $\mathrm{CO}_{2}$ increased from $\sim 0.3-0.4 \%$ up to slightly greater than $16 \%$. During this time the $\mathrm{N}_{2}$ and $\mathrm{H}_{2}$ contents varied from 74.4 to $78.6 \%$ and 0 to $1.1 \%$, respectively.

After $\sim 93$ minutes of operation, the particulate analysis sample train became clogged and it was decided to install a second train for another analysis. To prevent escape of the offgas into the lab during the sample train change out, power to the electrodes was reduced to $\sim 2-3 \mathrm{~kW}$. Opening the offgas system allowed air ingress into the system, with the result that $\mathrm{O}_{2}$ level increased and $\mathrm{CO}_{2}$ level decreased at the gas chromatograph. The increase in $\mathrm{O}_{2}$ and decrease in $\mathrm{CO}_{2}$ does not necessarily reflect changes in reactions taking place in the melter since the opening in the offgas system is beyond the melter. A graphical presentation of the changes observed in gas composition is shown in Figure 12. Tabulated data from all the runs are contained in Appendix C. 
Table VI. Arc Melter Run Summary

\begin{tabular}{|c|c|c|c|c|c|c|}
\hline $\begin{array}{l}\text { Run/ } \\
\text { Trial }\end{array}$ & Feed & $\begin{array}{l}\text { Mass of } \\
\text { Feed } \\
{[\mathrm{kg}]}\end{array}$ & $\begin{array}{l}\text { Mass of } \\
\text { Product } \\
{[\mathrm{kg}]}\end{array}$ & $\begin{array}{l}\text { Expected } \\
\text { Mass of } \\
\text { Product } \\
\text { [kg] }\end{array}$ & $\begin{array}{l}\text { Power } \\
\text { Input } \\
\text { [kWh] }\end{array}$ & Description \\
\hline $1 / 014$ & $\begin{array}{l}\text { Sandy Soil, } \\
\text { Clay Soil, and } \\
\text { Colemanite }\end{array}$ & $24.26 \mathrm{~kg}$ & $\begin{array}{l}\text { Trial not } \\
\text { completed }\end{array}$ & 20.00 & 29 & $\begin{array}{l}\text { Melt froze during probe swapping. } \\
\text { Electrode broke at threads. Arced to } \\
\text { head space. }\end{array}$ \\
\hline $2 / 015$ & $\begin{array}{l}\text { Sandy Soil, } \\
\text { Clay Soil, and } \\
\text { Colemanite }\end{array}$ & $23.39 \mathrm{~kg}$ & $\begin{array}{l}\text { Trial not } \\
\text { completed }\end{array}$ & 20.02 & 9 & $\begin{array}{l}\text { Used hollow electrode to introduce flux. } \\
\text { Interfered with arc stability causing melt } \\
\text { to freeze during the trial. Mauve glass } \\
\text { formed in the arc zone. }\end{array}$ \\
\hline $3 / 016$ & $\begin{array}{l}\text { Sandy Soil, } \\
\text { Clay Soil, and } \\
\text { Colemanite }\end{array}$ & $23.37 \mathrm{~kg}$ & $\begin{array}{l}\text { Trial not } \\
\text { completed }\end{array}$ & 20.00 & 34 & $\begin{array}{l}\text { Melt froze during probe swapping. } \\
\text { Formed a bowl due to viscosity of the } \\
\text { melt. }\end{array}$ \\
\hline $4 / 017$ & $\begin{array}{l}\text { Sandy Soil, } \\
\text { Clay Soil, and } \\
\text { Dolomitic } \\
\text { Limestone }\end{array}$ & $25.31 \mathrm{~kg}$ & $\begin{array}{l}\text { Trial not } \\
\text { completed }\end{array}$ & 20.00 & 22 & $\begin{array}{l}\text { Electrode feed system clogged } \\
\text { preventing fluxes from being added. } \\
\text { Melt froze while attempting to introduce } \\
\text { flux through plenum. }\end{array}$ \\
\hline $5 / 018$ & $\begin{array}{l}\text { Sandy Soil, } \\
\text { Clay Soil, and } \\
\text { Dolomitic } \\
\text { Limestone }\end{array}$ & $25.30 \mathrm{~kg}$ & 17.68 & 19.99 & 70 & $\begin{array}{l}\text { Used modified hollow electrode } \\
\text { configuration to blow air through the } \\
\text { electrode. Produced a gray product. }\end{array}$ \\
\hline $6 / 020$ & $\begin{array}{l}\text { Sandy Soil, } \\
\text { Clay Soil, and } \\
\text { Hydrated Lime }\end{array}$ & $23.22 \mathrm{~kg}$ & 18.65 & 20.00 & 70 & $\begin{array}{l}\text { Used modified hollow electrode to blow } \\
\text { air and hydrated lime into molten pool. } \\
\text { Produced a homogeneous, light gray } \\
\text { product. Unusual build-up of dust on } \\
\text { crucible bevel. }\end{array}$ \\
\hline $7 / 021$ & $\begin{array}{l}\text { Sandy Soil and } \\
\text { Hydrated Lime }\end{array}$ & $22.67 \mathrm{~kg}$ & 15.16 & 20.00 & 64 & $\begin{array}{l}\text { Used modified hollow electrode to blow } \\
\text { air and hydrated lime into molten pool. } \\
\text { Produced a homogeneous, medium gray } \\
\text { product. Unusual build-up of dust on } \\
\text { crucible bevel. }\end{array}$ \\
\hline $8 / 022$ & $\begin{array}{l}\text { Sandy Soil, } \\
\text { Hydrated Lime, } \\
\text { and Debris }\end{array}$ & 23.212 & $\begin{array}{l}14.92 \text { glass } \\
4.14 \\
\text { unmelted } \\
\text { batch } \\
19.06 \text { total }\end{array}$ & 20.00 & 70 & $\begin{array}{l}\text { Used modified hollow electrode to blow } \\
\text { air and hydrated lime into molten pool. } \\
\text { Produced a homogeneous blue/lavender } \\
\text { product. Some unmelted feed near the } \\
\text { edges. Unusual build-up of dust on } \\
\text { crucible bevel. }\end{array}$ \\
\hline
\end{tabular}



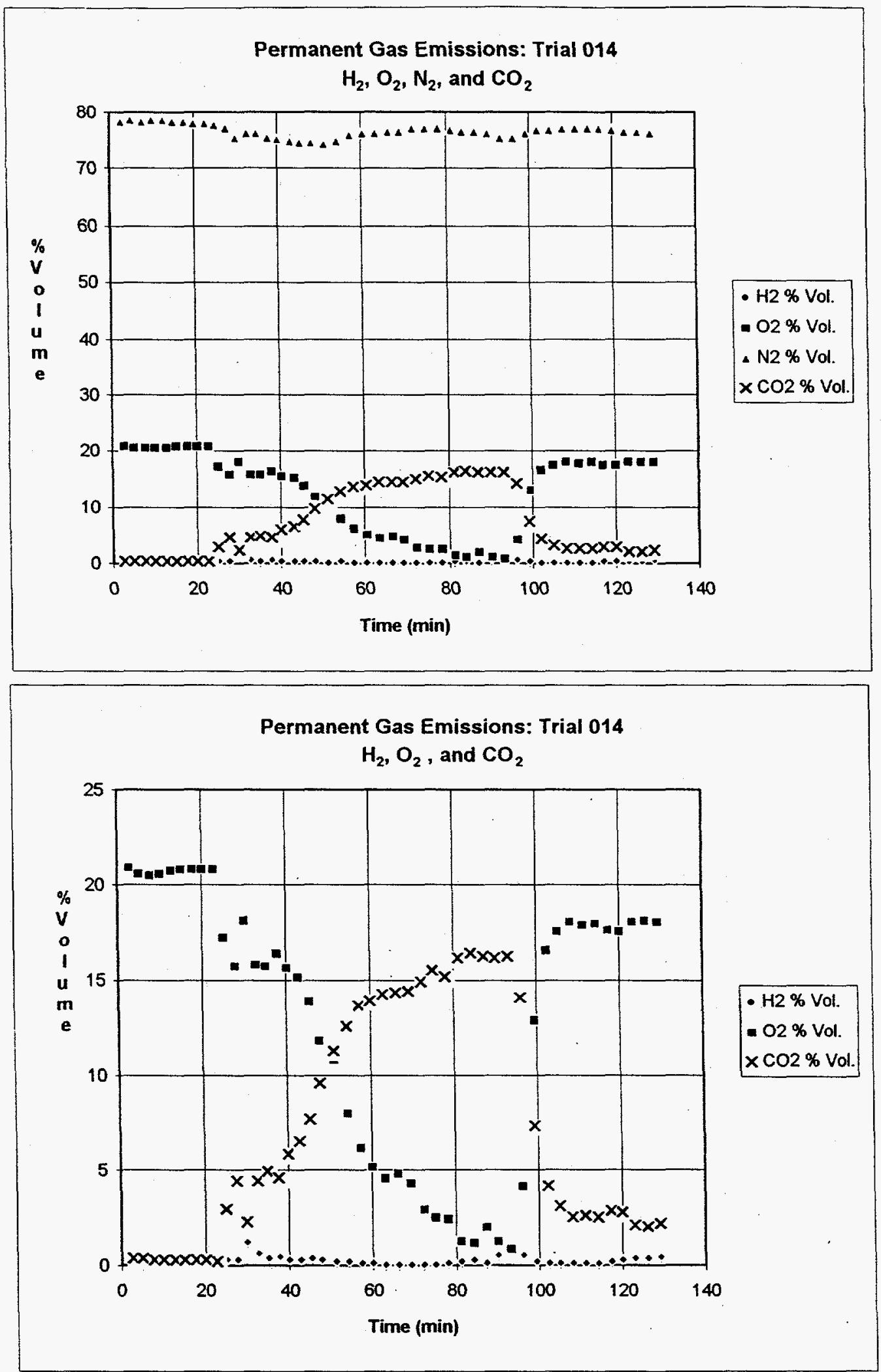

Figure 12 Offgas composition changes observed during Run \#1 
The second sample train was installed after approximately 10 minutes and the electrodes were separated to reestablish the previous operating conditions of $\sim 14 \mathrm{~kW}$. Although unknown at the time, the melt that had been created at the bottom of the melter solidified around the electrodes during the time that the power level had been reduced. When an attempt was made to separate the electrodes, the upper electrode broke at the point where it threaded into the extension. When the arc was reestablished, it occurred between the top of the broken electrode and the bottom of the extension, about midway along the thickness of the refractory in the lid of the melter. This situation was realized when molten refractory was seen dripping from the top of the meiter while the melter operation was being observed through the video camera. The run was terminated immediately.

After disassembling the melter, it was discovered that establishing the arc at the electrode breakage point resulted in destruction of some of the refractory in the melter roof. This refractory melted and ran down the electrode, giving it the appearance of a candle with heavy wax build-up along its length. This and the bowl-shaped sintered charge are shown in Figure 13(a). Figure 13(b) shows that fusion of the soil was limited to a fairly narrow region between the top and bottom electrodes, forming a small amount of glass. The glass was medium gray in color with swirls of lighter gray. Outside the arc zone, the remaining soil was sintered, creating a bowl-shaped mass, but showed no evidence of melting.

\section{Run 2 (ID \#015)}

After repairing the damaged melter roof, a batch containing a 50:50 mixture of sandy soil and clay soil, plus $0.5 \%$ each of copper and cerium, was prepared. $25 \%$ colemanite flux was to be injected into the melt through a hollow electrode. Start up of the run proceeded similarly to run \#1. After the arc was stabilized, injection of the colemanite flux was begun. It was observed that the arc was very unstable while the flux and air were being injected through the hollow electrode. Several times the arc extinguished but could be reignited. During one attempt at reigniting the arc, the electrode stuck in the glass at the bottom of the crucible and broke. The run was terminated after $9 \mathrm{kWh}$ vs a target of 80 $\mathrm{kWh}$. Figure 14 shows the sintered batch after removal from the crucible. Once again, the electrode broke at the base of the threaded stub. A small quantity of mauve colored glass was formed during this run. Permanent gas analysis results are shown in Figure 15 and Appendix C. 


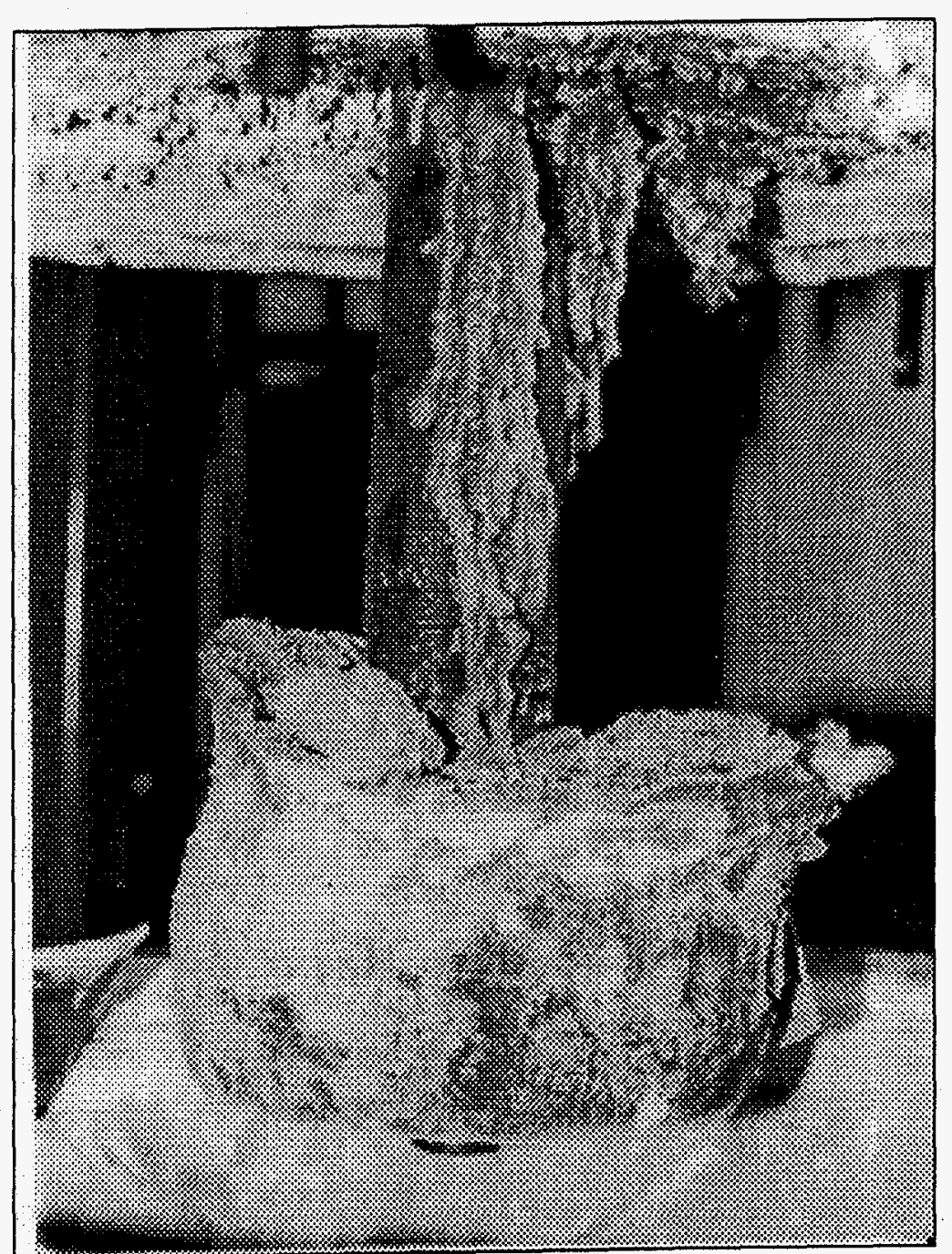

(a) Sintered mass created when charge cooled during sample train change-out. Also shown is melter refractory that ran down electrode.

Figure 13. Product Formed During Run

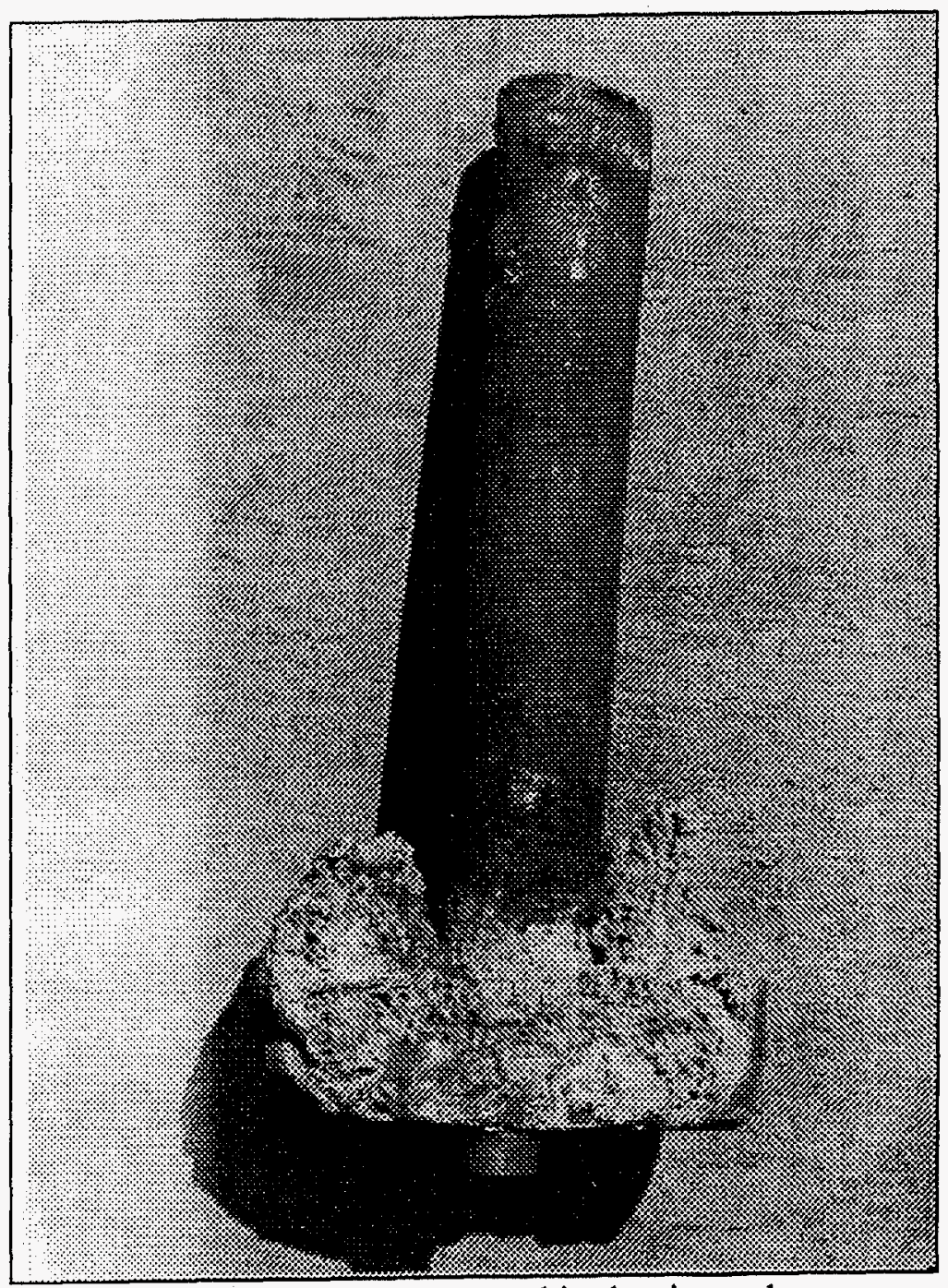

(b) Example of small fusion zone created in the sintered mass between the electrodes. Also note damage at top of electrode caused by arcing. 


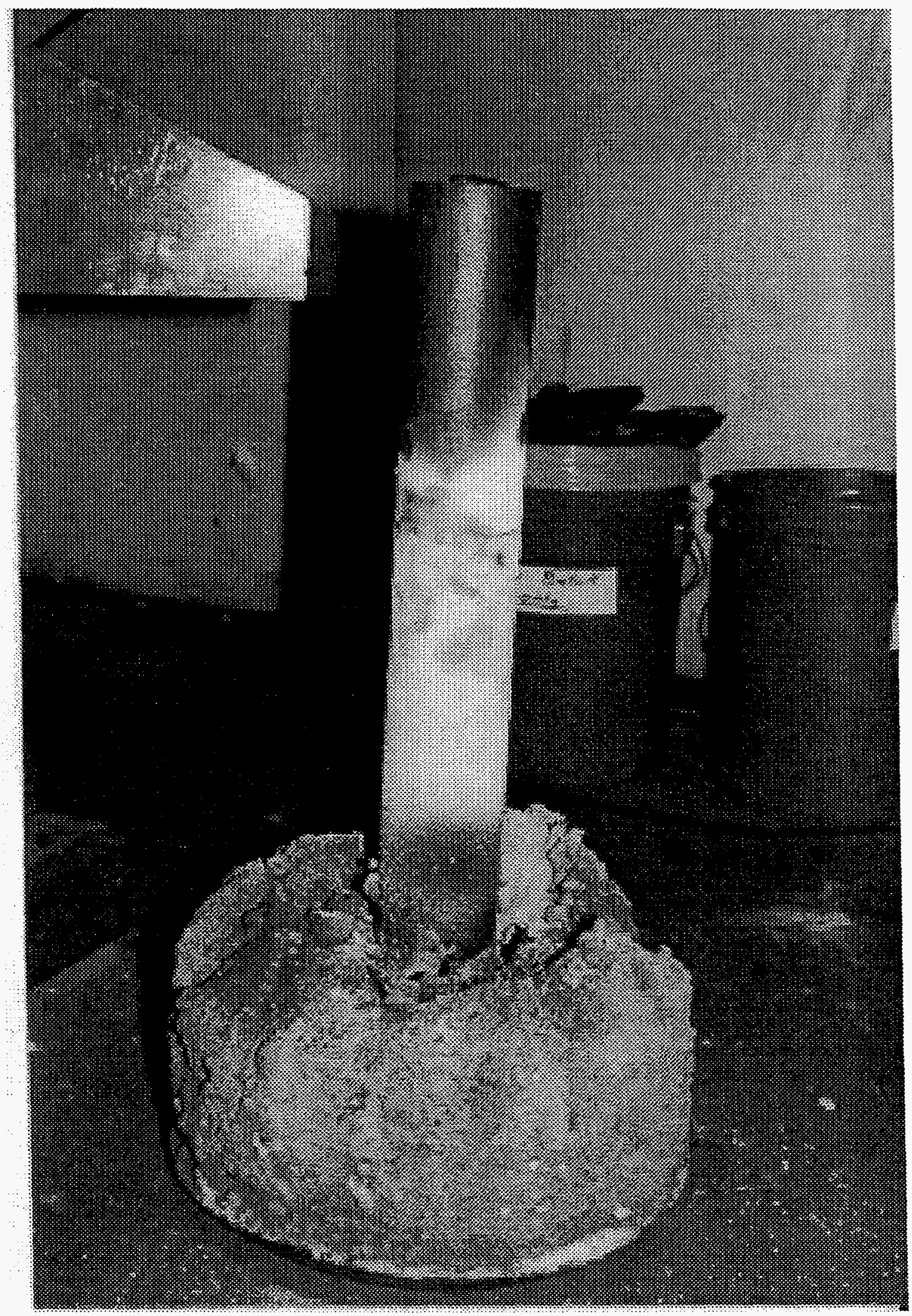

Figure 14. Product From Run 2. 

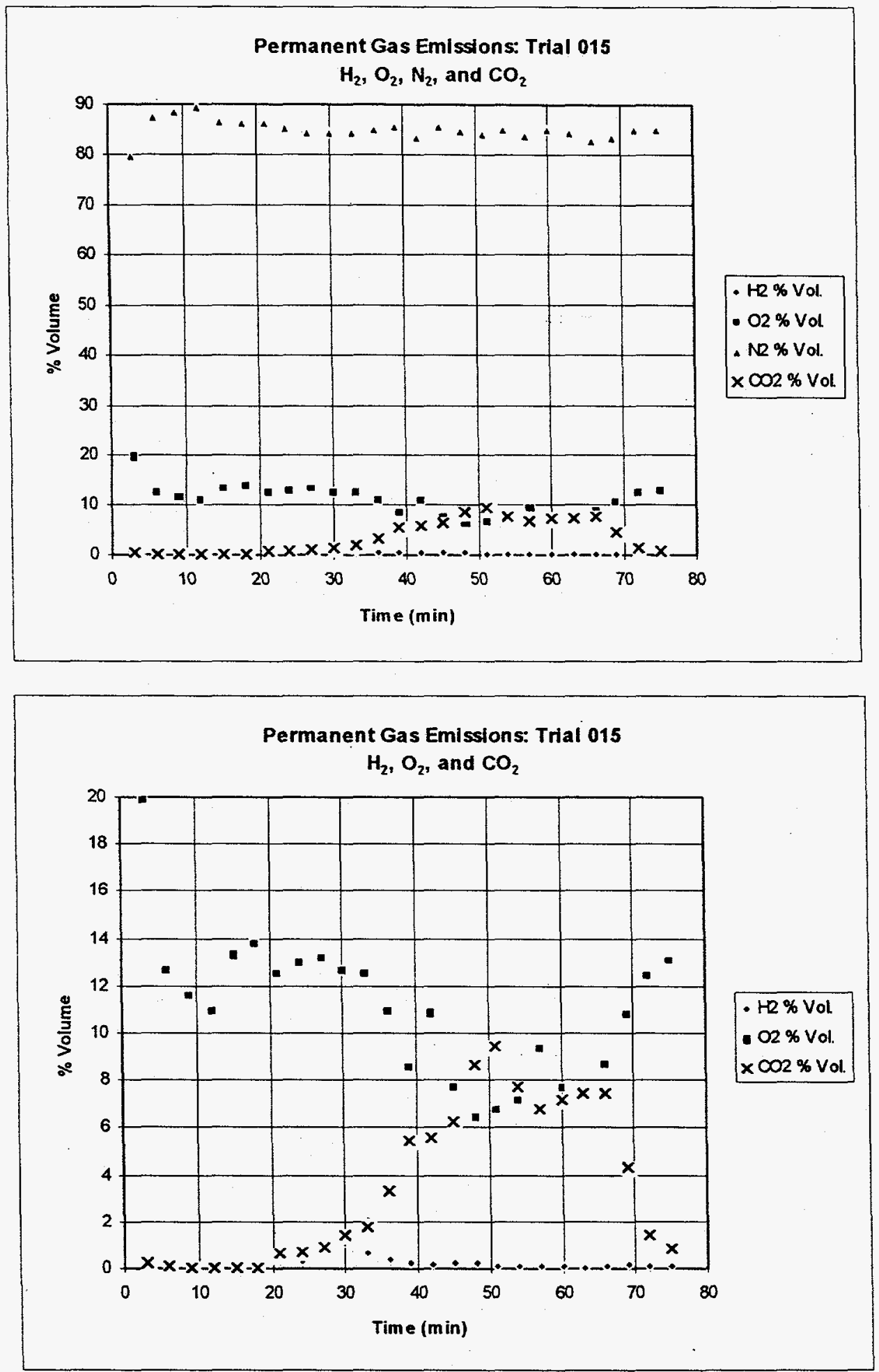

Figure 15. Offgas composition changes observed during Run \#2. 


\section{Run 3 (ID \#016)}

This run also consisted of a 50:50 blend of sandy and clay soil, but with the colemanite flux blended into the soil rather than being injected as in Run 2. After stabilizing the arc, only air was injected into the melter through the hollow electrode. The purpose of this test was to determine if the previously observed arc instability was caused by the injected flux, or by the injection of air alone. Arc instability was reduced greatly during this test, confirming that arc instability occurred when flux flowed between the two electrodes.

During the run the off gas particulate sampling train again became clogged. Once again an attempt was made to change it out, but within a greatly reduced time frame. Even though the change out required only about 1 minute, the electrode froze in the melt. The run was terminated after $34 \mathrm{kWh}$. A small quantity of gray glass was produced during the run. Permanent gas analysis results are shown in Figure 17 (see next page) and Appendix C.

Post-run examination of the upper electrode revealed that one side eroded much faster than the other. This is attributed to a slight misalignment of the upper and lower electrodes. Figure 16, although not clearly showing the side-to-side erosion, does provide an indication of the damage realized by the electrode due to injecting air through it. The base of the electrode is rounded and the central hole is enlarged. During this run 758 gms $(18.1 \%)$ of the top electrode was destroyed. $(2.9 \% / \mathrm{kWh})$

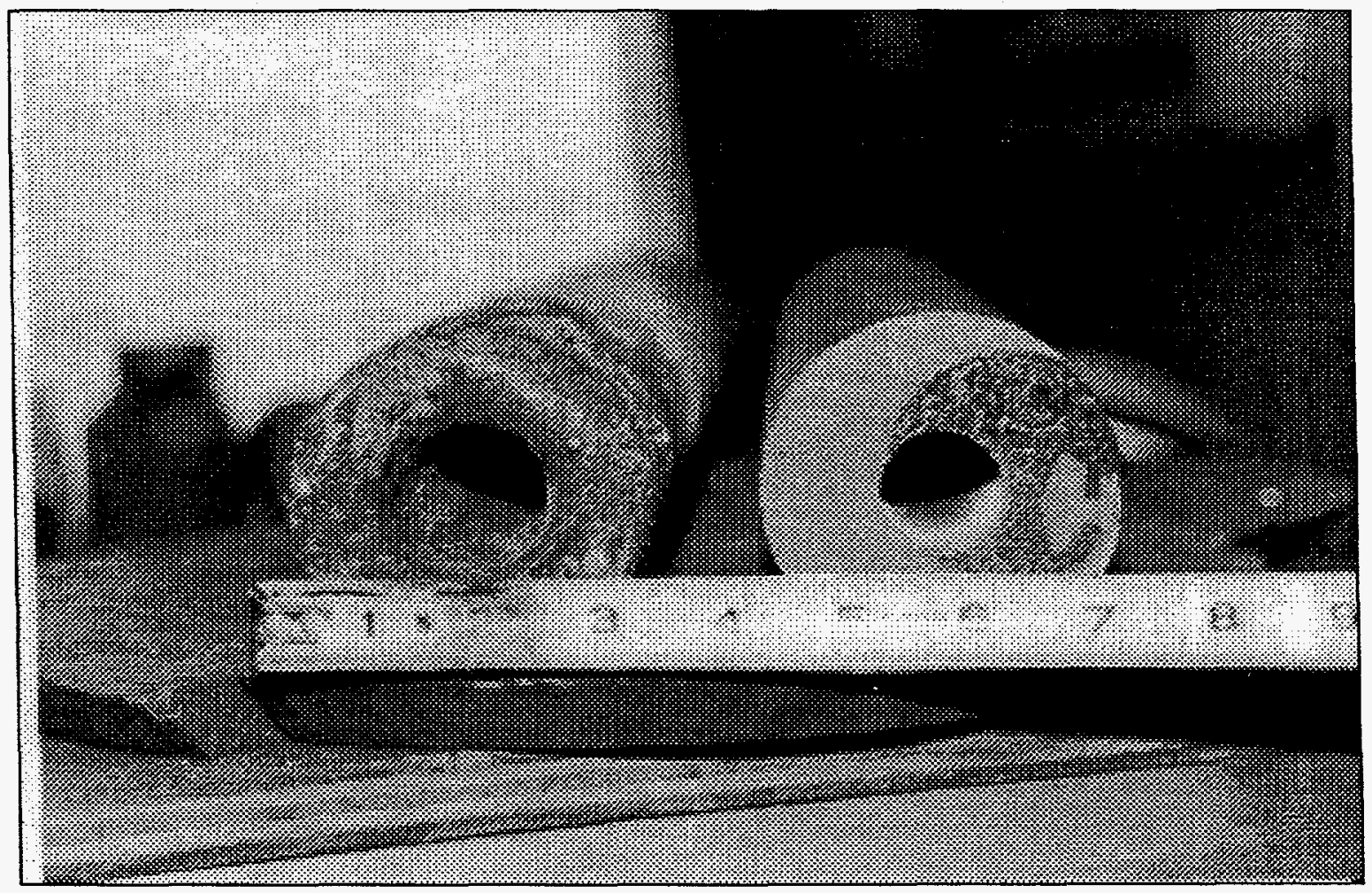

Figure 16. Example of Electrode Damage Occurring During Air Injection. 

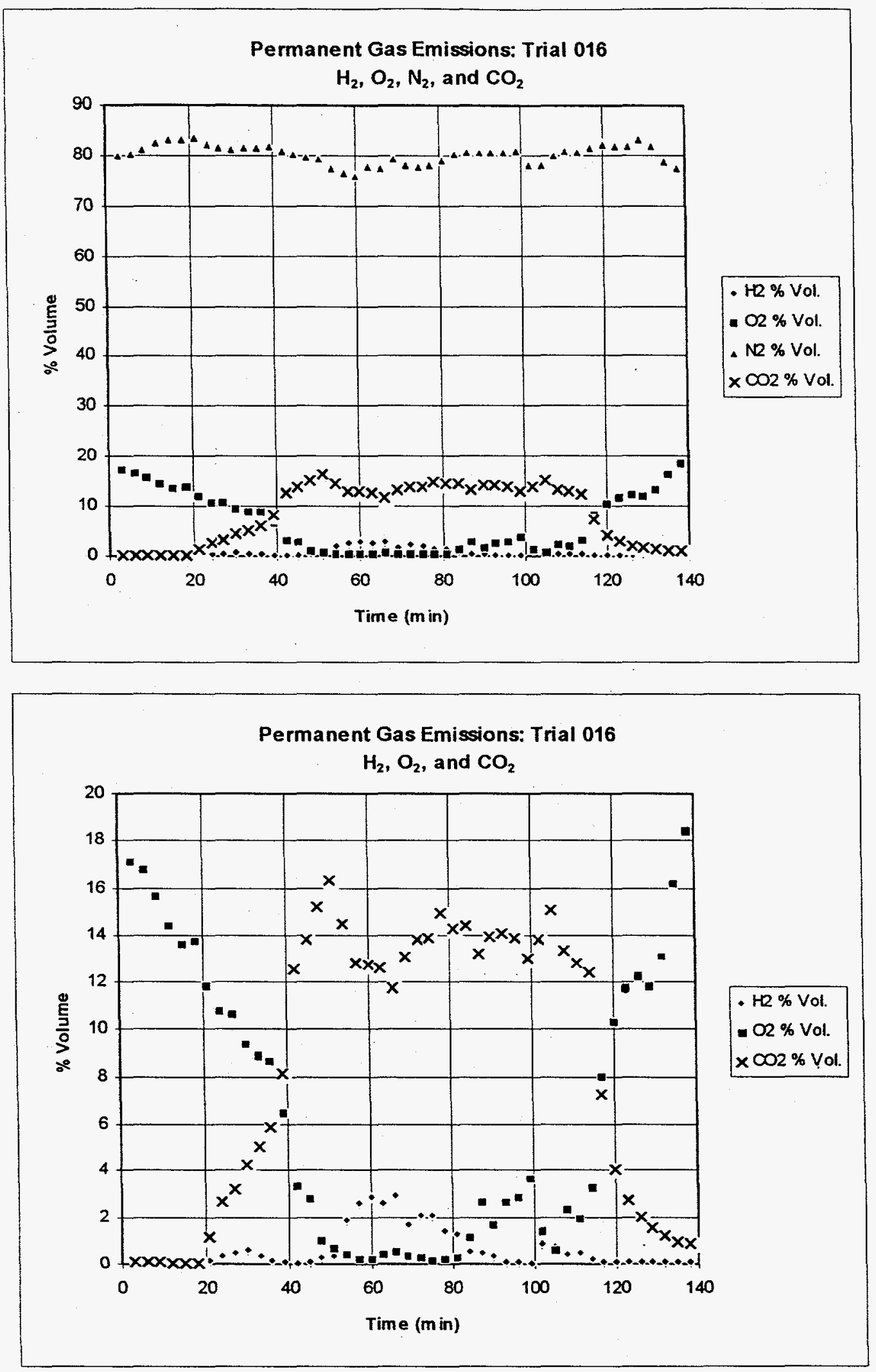

Figure 17. Offgas composition changes observed during Run \#3. 


\section{Run 4 (ID \#017)}

The modified electrode, shown in Figure 6 and discussed previously, was used during this run for flux injection. Dolomitic lime was selected in favor of colemanite because of the high viscosity of the colemanite flux melts. The batch was a 50:50 mixture of sandy and clay soil, with $0.5 \% \mathrm{Cu}$ and $\mathrm{Ce}$ radionuclide surrogate materials. The pelletized lime would not feed into the melter and eventually clogged the feed system. The run was terminated after $22 \mathrm{kWh}$. A small quantity of gray glass was produced during the run. Permanent gas analysis results are shown in Figure 19 (see next page) and Appendix C.

\section{Run 5 (ID \#018)}

This run also consisted of a 50:50 blend of sandy and clay soil with $\mathrm{Cu}$ and $\mathrm{Ce}$ radionuclide surrogate additions, but with the dolomitic lime flux blended into the soil rather than being injected as in Run 4. After stabilizing the arc, only air was injected into the melter through the modified hollow electrode. The purpose of this test was to determine the effect of using dolomitic lime as the flux.

This run was successfully terminated after $70 \mathrm{kWh}$ with $17.68 \mathrm{~kg}$ of gray glass produced compared to a predicted $19.99 \mathrm{~kg}$. Permanent gas analysis results are shown in Figure 20 and Appendix C.

Severe erosion of the electrode air exit holes was observed at the completion of this run. As shown in Figure 18, the left side of the electrode shows nearly complete erosion between the front and rear air exit holes. This electrode experienced 766 gms weight loss. $(21.2 \%$ total loss or $0.3 \% / \mathrm{kWh}$.)

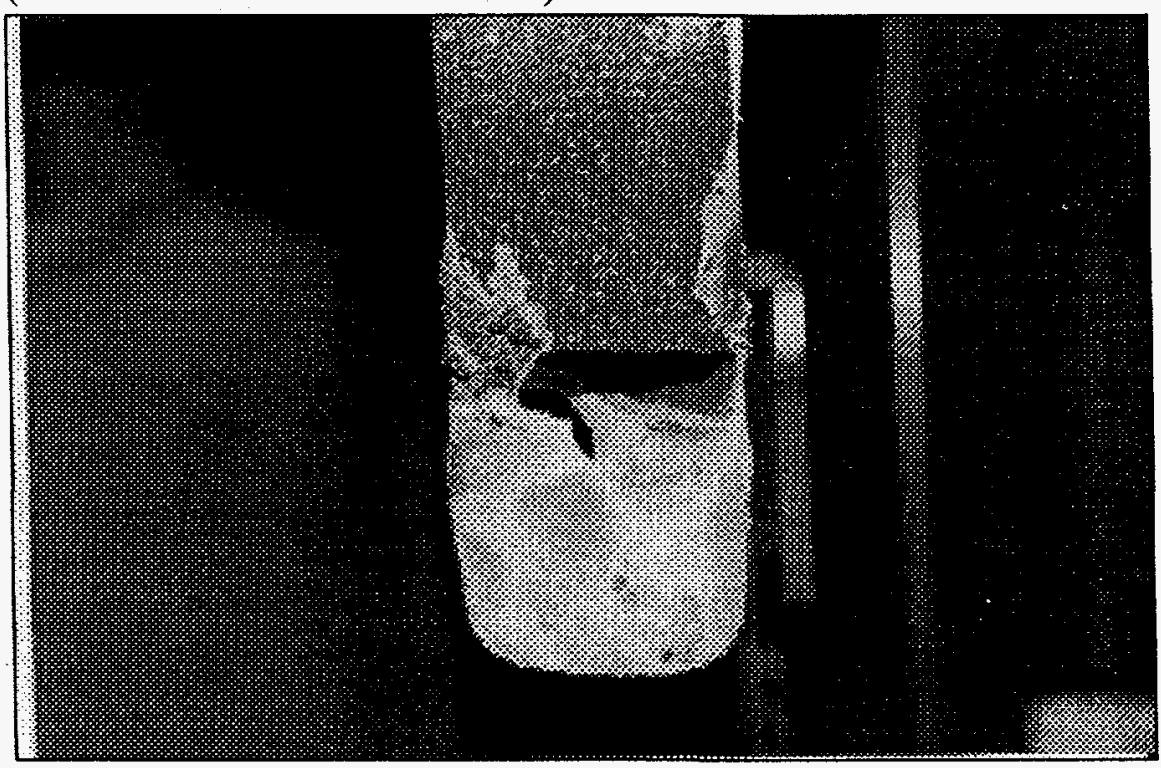

Figure 18. Damage Experienced by the Modified Electrode Caused by Air Injected into the Melt during Run 5. 

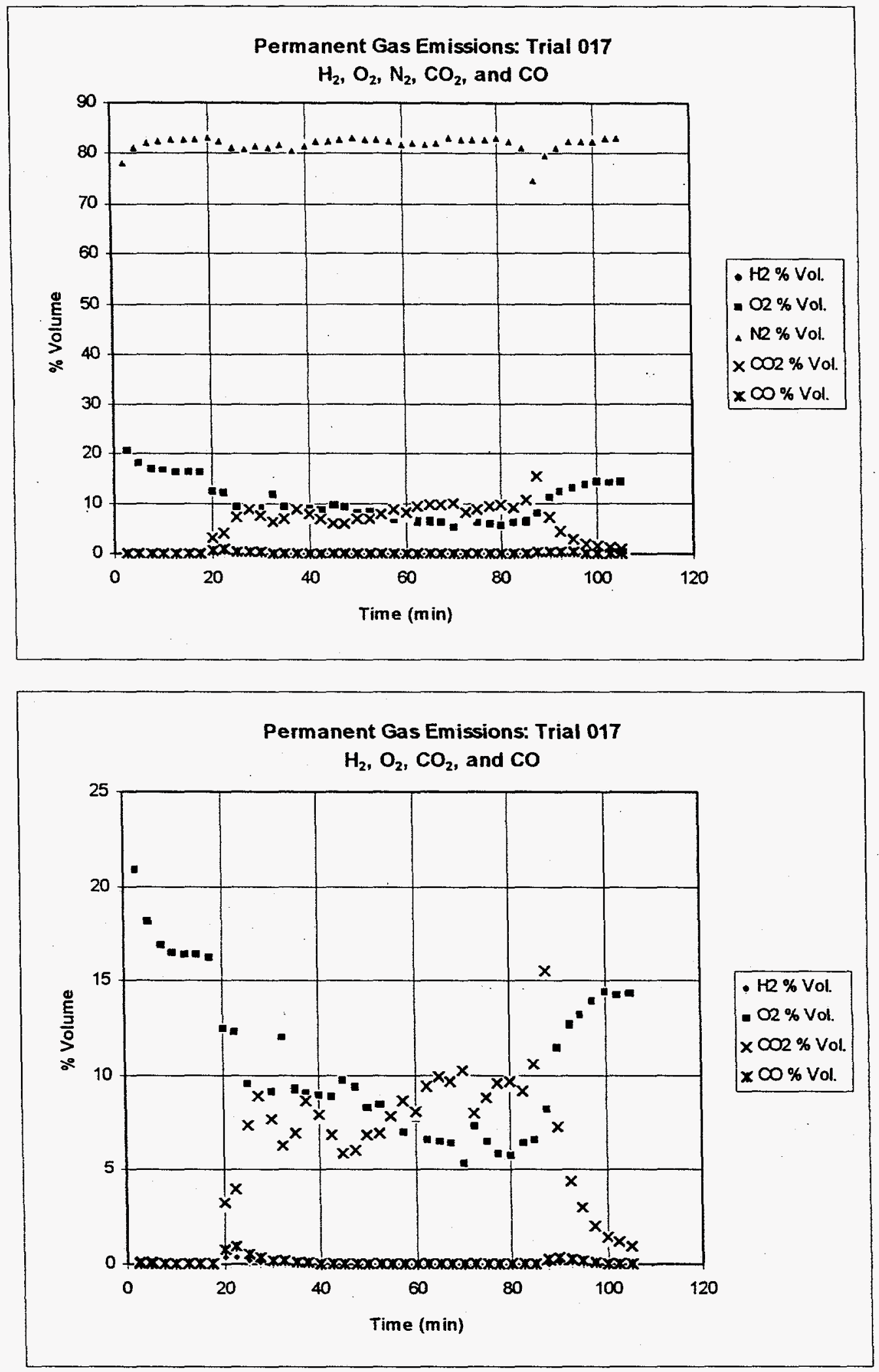

Figure 19. Offgas composition changes observed during Run \#4. 

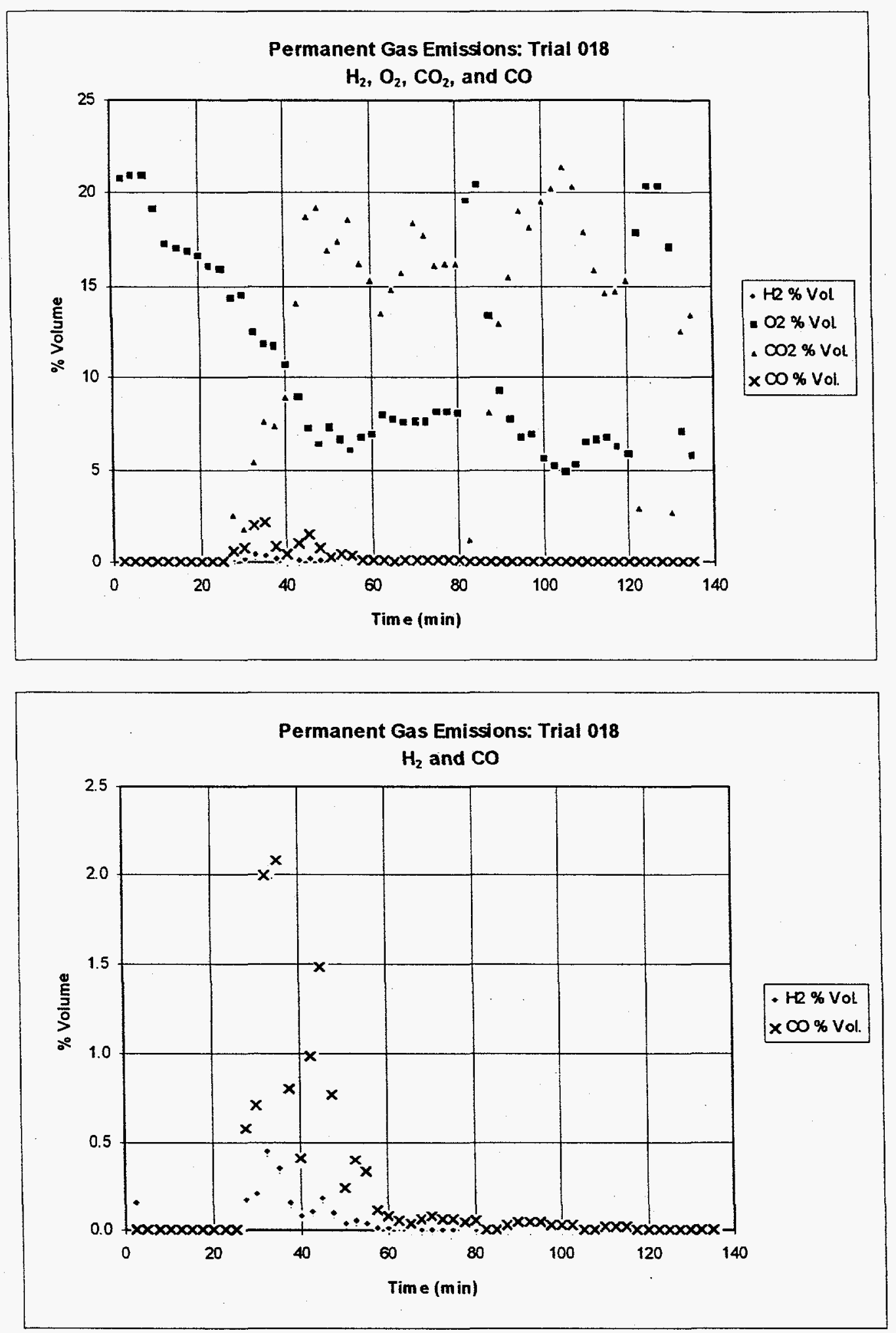

Figure 20. Offgas composition changes observed during Run \#5. 
This run demonstrated that soil could be processed to a glassy form in the EPI melter by preblending the flux into the soil and injecting air through the electrode. However, the form of the flux was not suitable for the feeding mechanism that was fabricated for this project and the ability of flux additions through the electrode had not been demonstrated. The last three runs were conducted with finer size, hydrated lime.

\section{Run 6 (ID \#020)}

The batch was a $50: 50$ mixture of sandy soil and clay soil, with $0.5 \% \mathrm{Cu}$ and $\mathrm{Ce}$ radionuclide surrogate additions. $25 \%$ hydrated lime flux was injected into the melt through a modified hollow electrode. The purpose of this run was to attempt injection of the finer particle size lime flux into the melt. This run progressed smoothly until terminated by the operator at $70 \mathrm{kWh}$. Permanent gas analysis results are shown in Figure 22 (see next page) and Appendix C.

A homogeneous, light gray, glassy product weighing $18.65 \mathrm{~kg}$ was formed and is shown in Figure 21. (The predicted recovery weight was $20 \mathrm{~kg}$.) One unusual feature of this run was the copious amount of white particulate matter that was present on the bevel of the crucible after the run, shown in Figure 23. This build-up is attributed to the fineness of the flux; it is believed that some of the flux was carried away from the surface of the melt and was deposited on the crucible bevel.

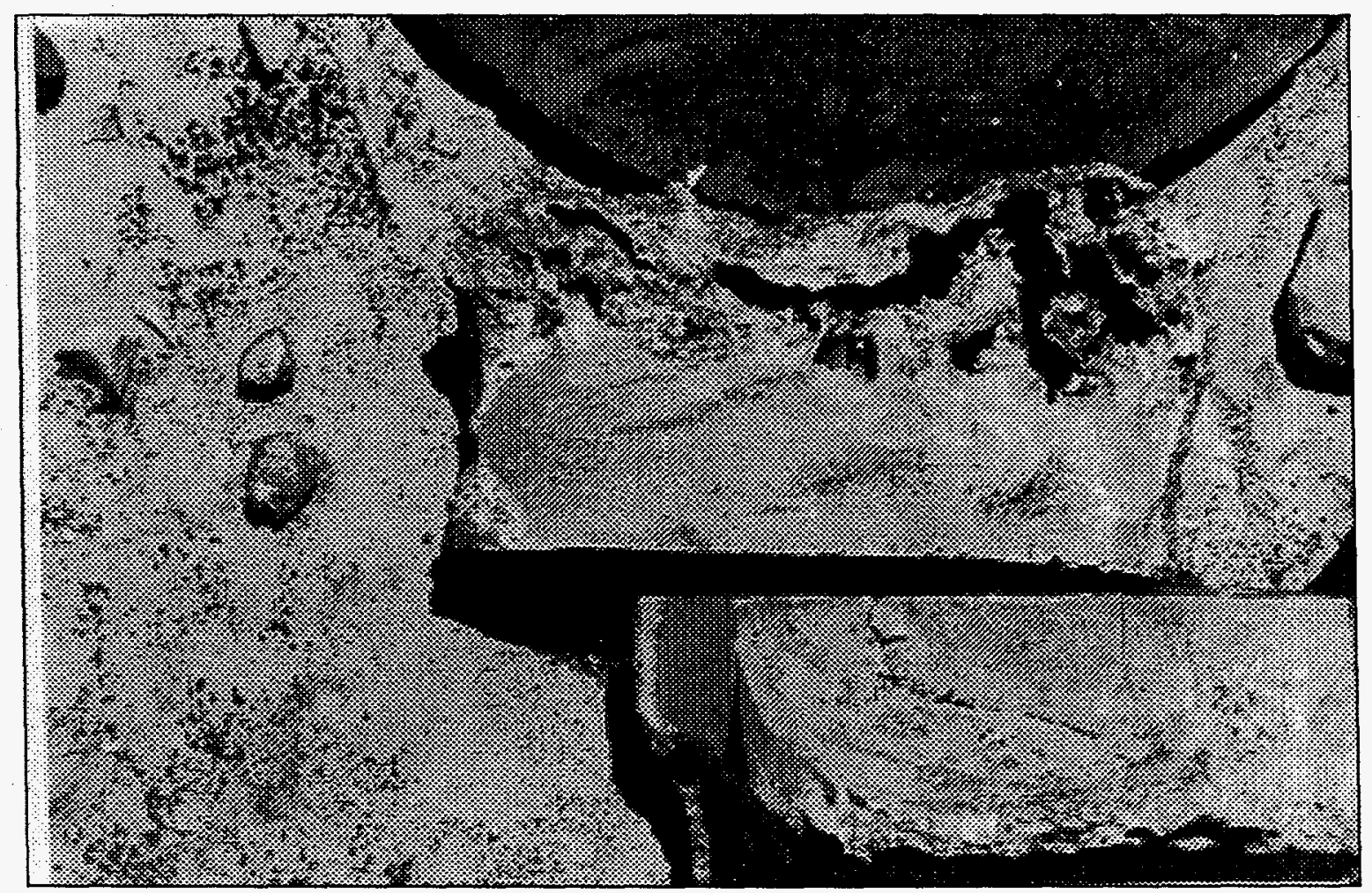

Figure 21. Homogeneous Glassy Product Produced During Run 6. 

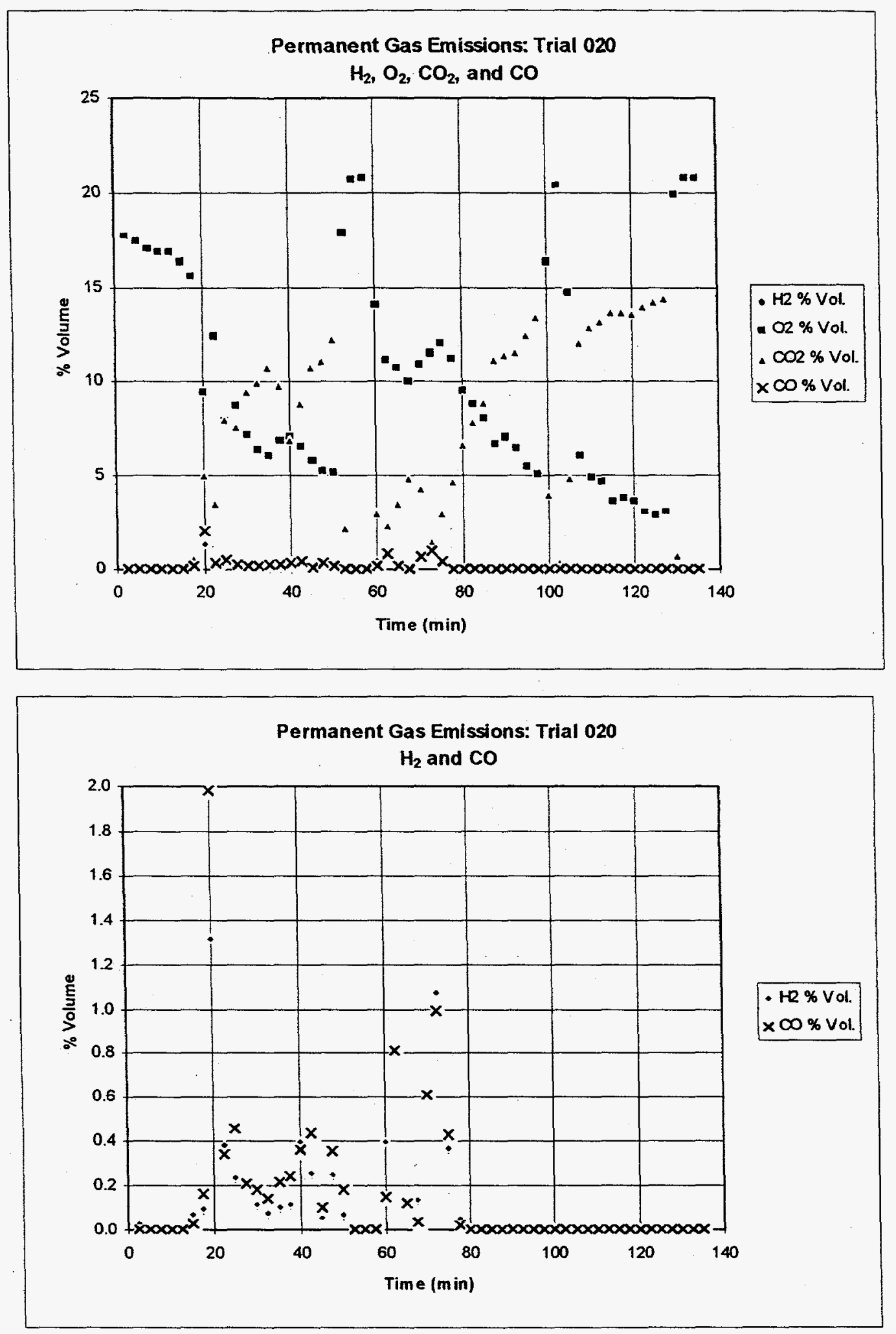

Figure 22. Offgas Composition Changes Observed During Run \#6. 


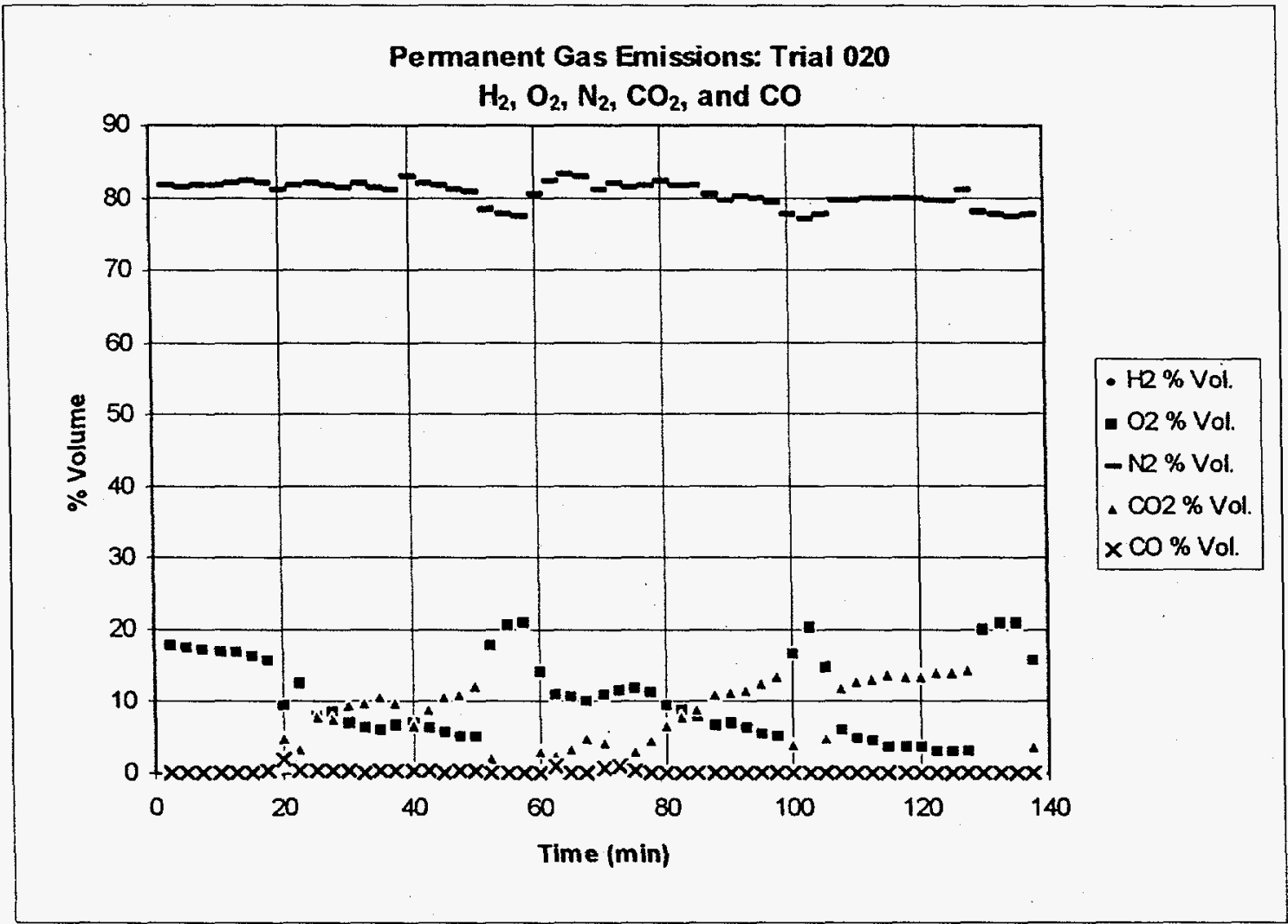

Figure 22. Offgas Composition Changes Observed During Run \#6. (cont.)

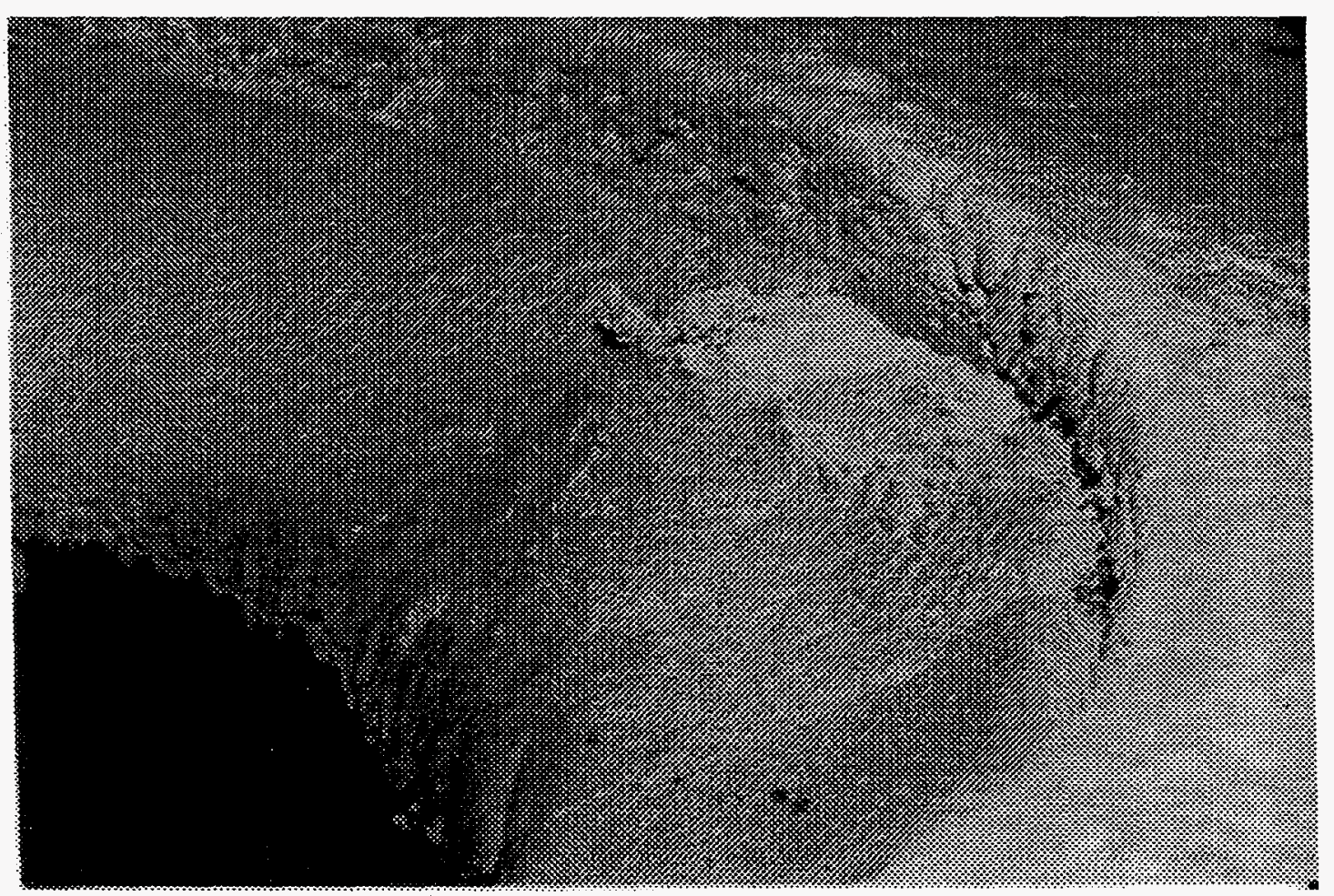

Figure 23. Flux Build-up on Rim of Crucible. 


\section{Run 7 (ID \#021)}

This batch was composed solely of sandy soil with $25 \%$ hydrated lime flux to be injected into the melt through a modified hollow electrode. The purpose of this run was to verify that the higher melting point sandy soil could also be successfully processed using the approach used for the sandy and clay soil mix. This run also progressed smoothly and was terminated by the operator after $64 \mathrm{kWh}$. A homogeneous, medium gray, glassy product weighing $15.16 \mathrm{~kg}$ was formed. (The predicted recovery weight was $20 \mathrm{~kg}$.) Permanent gas analysis results are shown in Figure 24 and Appendix C. This run also showed a build-up of particulate matter on the crucible bevel.

\section{Run 8 (ID \#022)}

This batch was also sandy soil, but simulated pieces of debris were placed on the top of the batch, as shown in Figure 25. These consisted of an $884 \mathrm{gm}, 0.25$ " thick stainless steel disk, a $152 \mathrm{gm}$ piece of threaded rod, and a $1,430 \mathrm{gm}$ piece of fiberglass reinforced concrete. $25 \%$ hydrated lime flux (based on charge weight exclusive of debris) was injected into the soil during the run using a modified electrode. This run progressed smoothly, producing $14.92 \mathrm{~kg}$ of a blue/lavender glass (vs $20 \mathrm{~kg}$ calculated) after 70 $\mathrm{kWh}$. The metallic debris melted during the run and settled at the bottom of the crucible where it reacted with the bottom plate. (The bottom plate is a sacrificial graphite disk used to protect the crucible.) $4.14 \mathrm{~kg}$ of unmelted batch material remained near the edges of the melt, resulting in $19.06 \mathrm{~kg}$ of material being recovered after the run. 

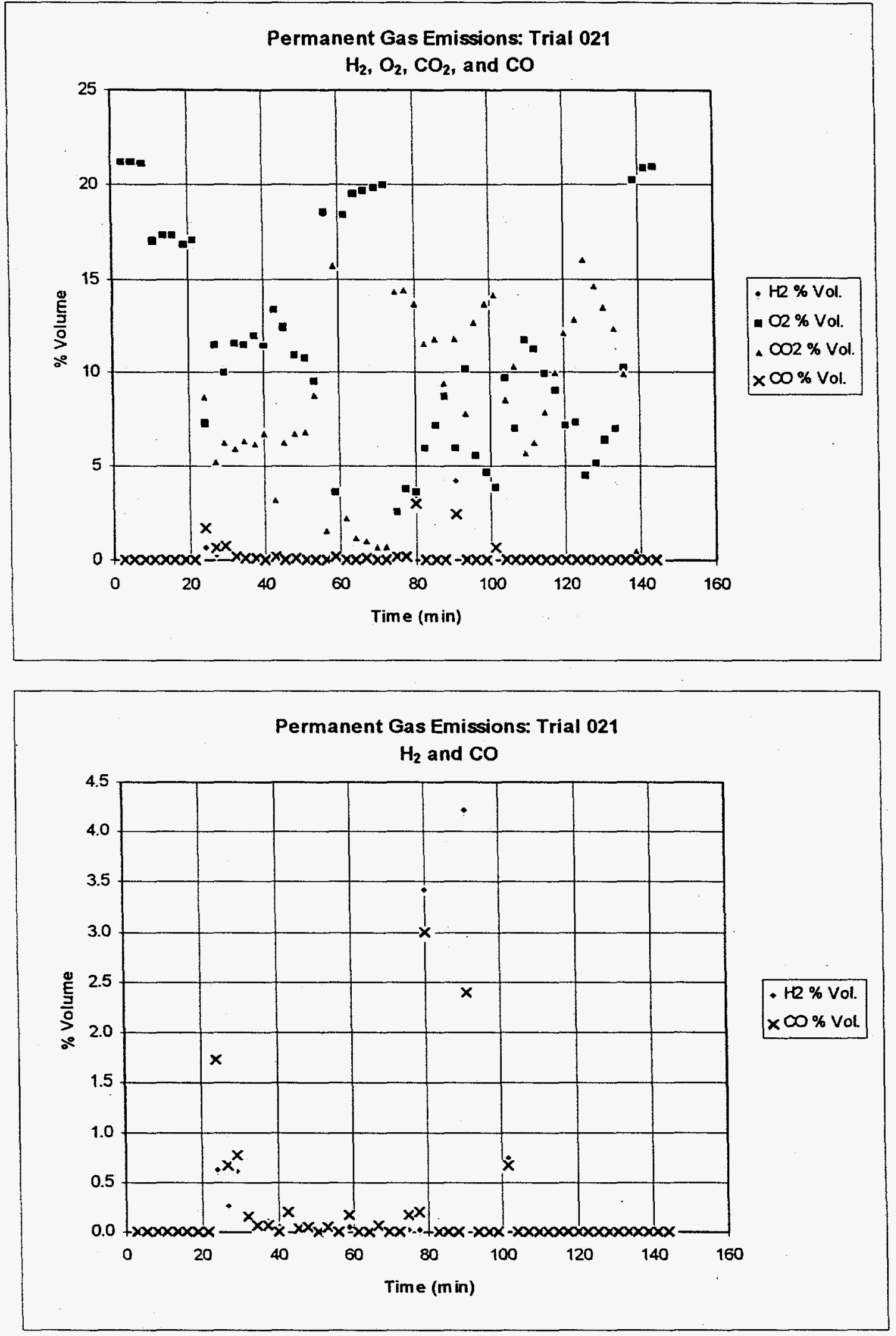

Figure 24. Offgas Composition Changes Observed During Run \#7. 


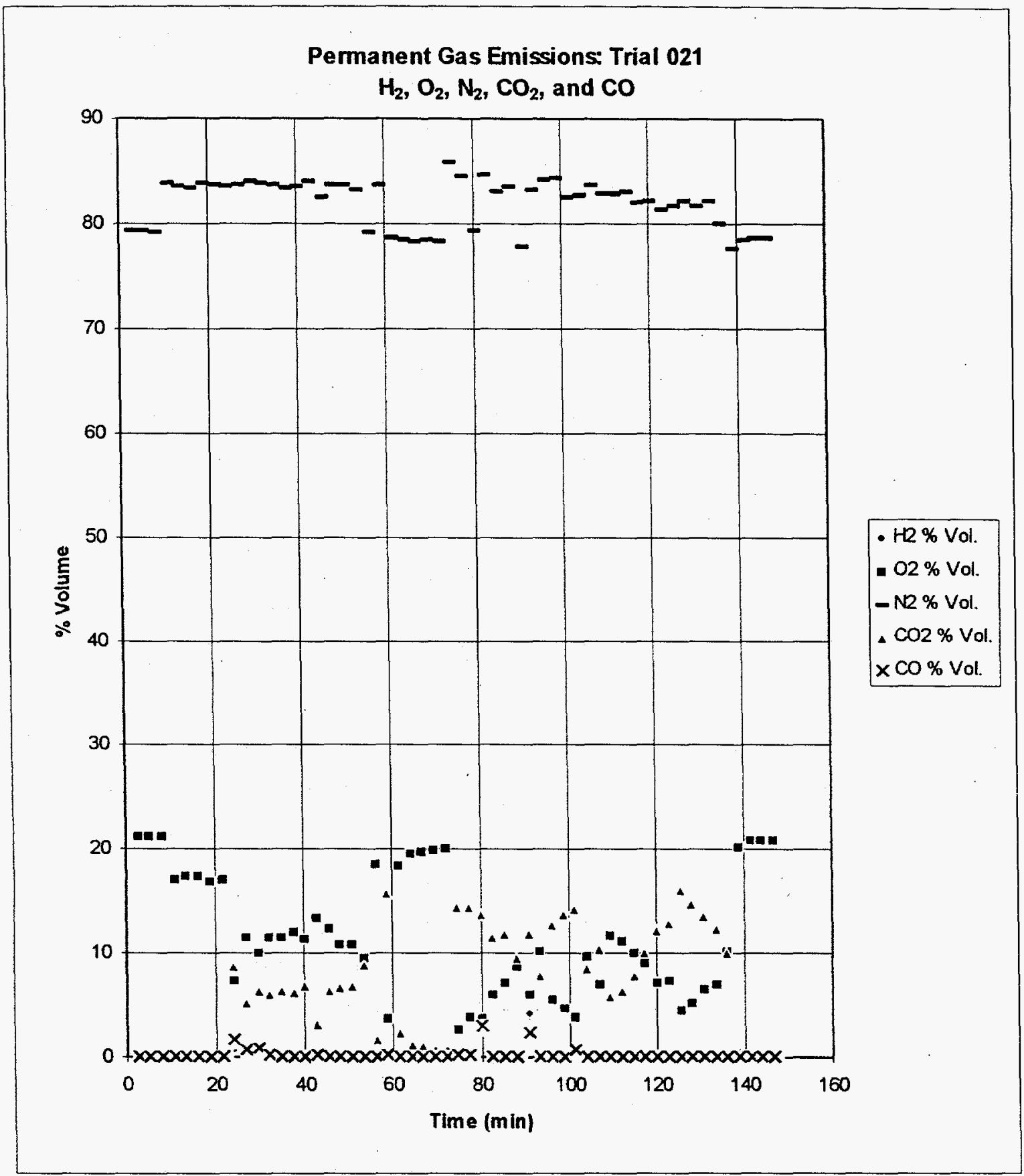

Figure 24. Offgas Composition Changes Observed During Run \#7. (cont.) 


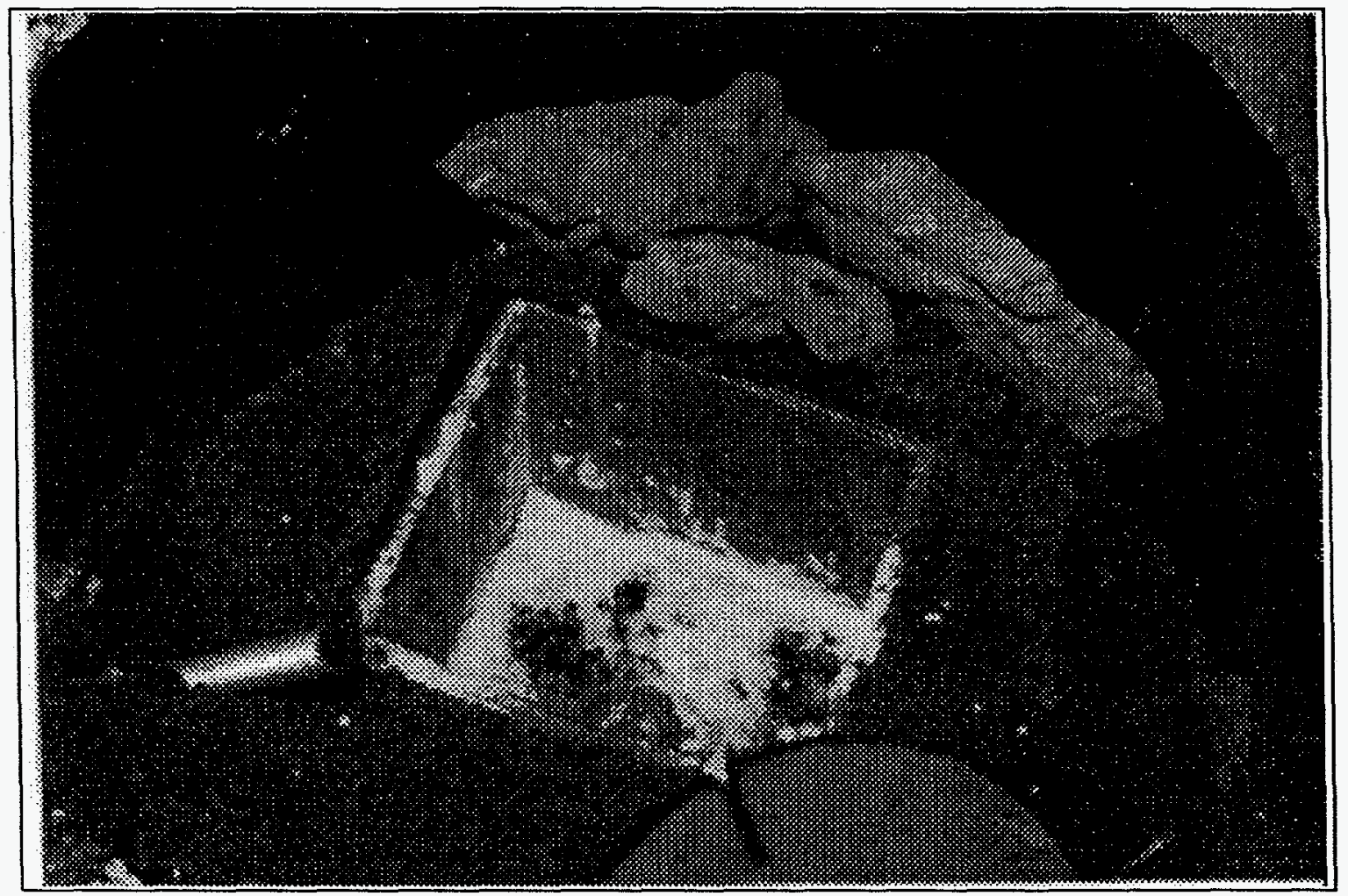

Figure 25. Placement of debris for Run 8. Note that access to the bottom electrode is provided by a rectangular box.

Permanent gas analysis results are shown in Figure 26 and Appendix C. This run also showed a build-up of particulate matter on the crucible bevel.

\section{Particulate analysis}

Although the intended sample time was one hour, the actual sample time was less due to the filter becoming clogged with particulate matter. The following results were obtained:

Table VII Particulate analysis result summarized for all runs

\begin{tabular}{|c|c|c|c|}
\hline $\begin{array}{c}\text { Run/ } \\
\text { Trial }\end{array}$ & $\begin{array}{c}\text { Sample Duration } \\
\text { (minutes) }\end{array}$ & $\begin{array}{c}\text { Particulate Concentration } \\
\left(\mathbf{g m} / \mathbf{m}^{\mathbf{3}}\right)\end{array}$ & $\begin{array}{c}\text { Moisture Content (\% by } \\
\text { standard volume) }\end{array}$ \\
\hline $1 / 014$ & 31.0 & 28.4 & 11.4 \\
\hline $2 / 015$ & 54.2 & 15.5 & 10.1 \\
\hline $3 / 016$ & 25.0 & 34.6 & 12.8 \\
\hline $4 / 017$ & & & 7.9 \\
\hline $5 / 018$ & 21.9 & 9.0 & 23.4 \\
\hline $6 / 020$ & 26.1 & 22.9 & 15.0 \\
\hline $7 / 021$ & 19.7 & 28.5 & 21.5 \\
\hline $8 / 022$ & 30.0 & 34.5 & \\
\hline
\end{tabular}



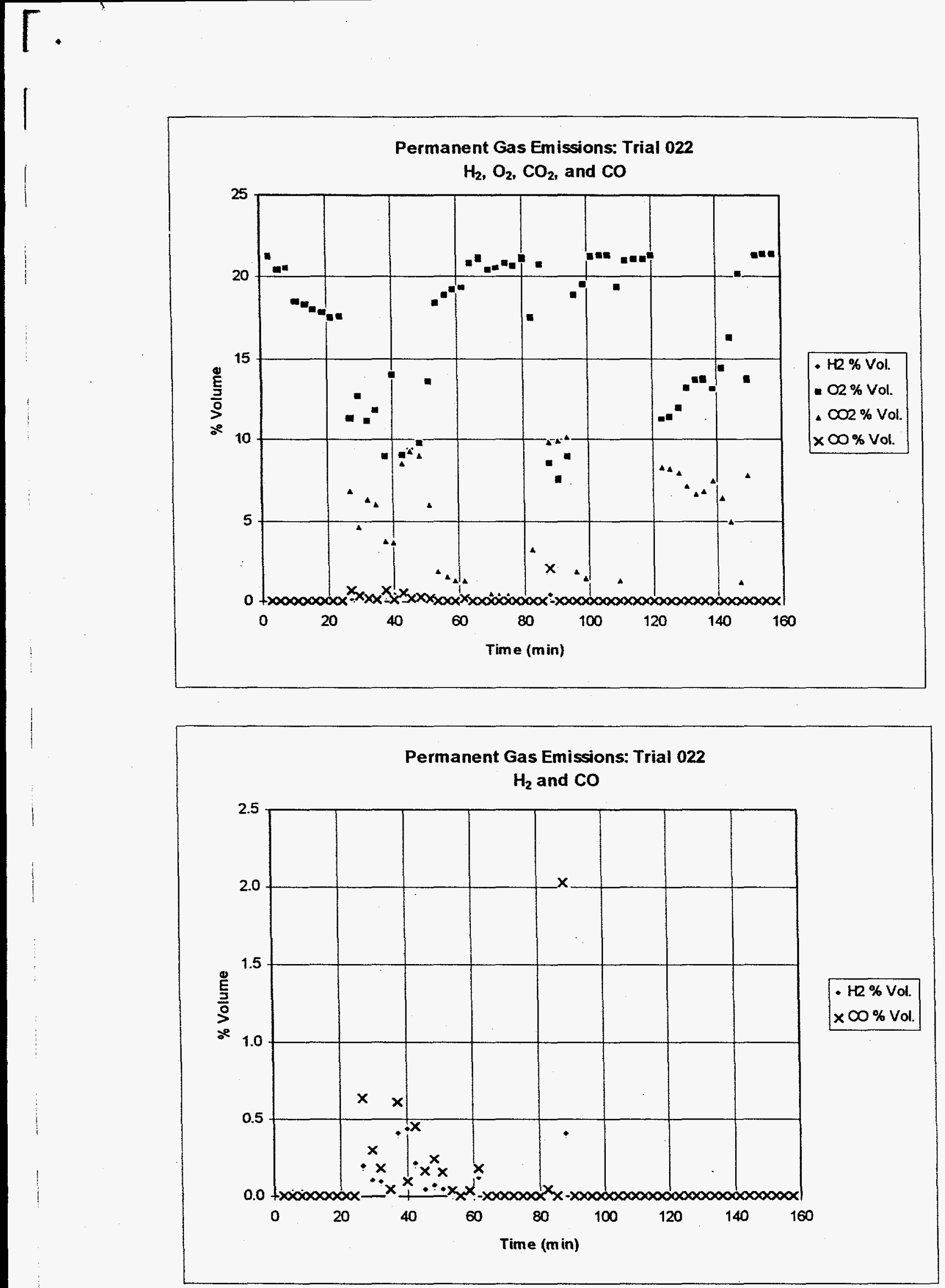

Figure 26. Offgas composition changes observed during Run $\#$. 


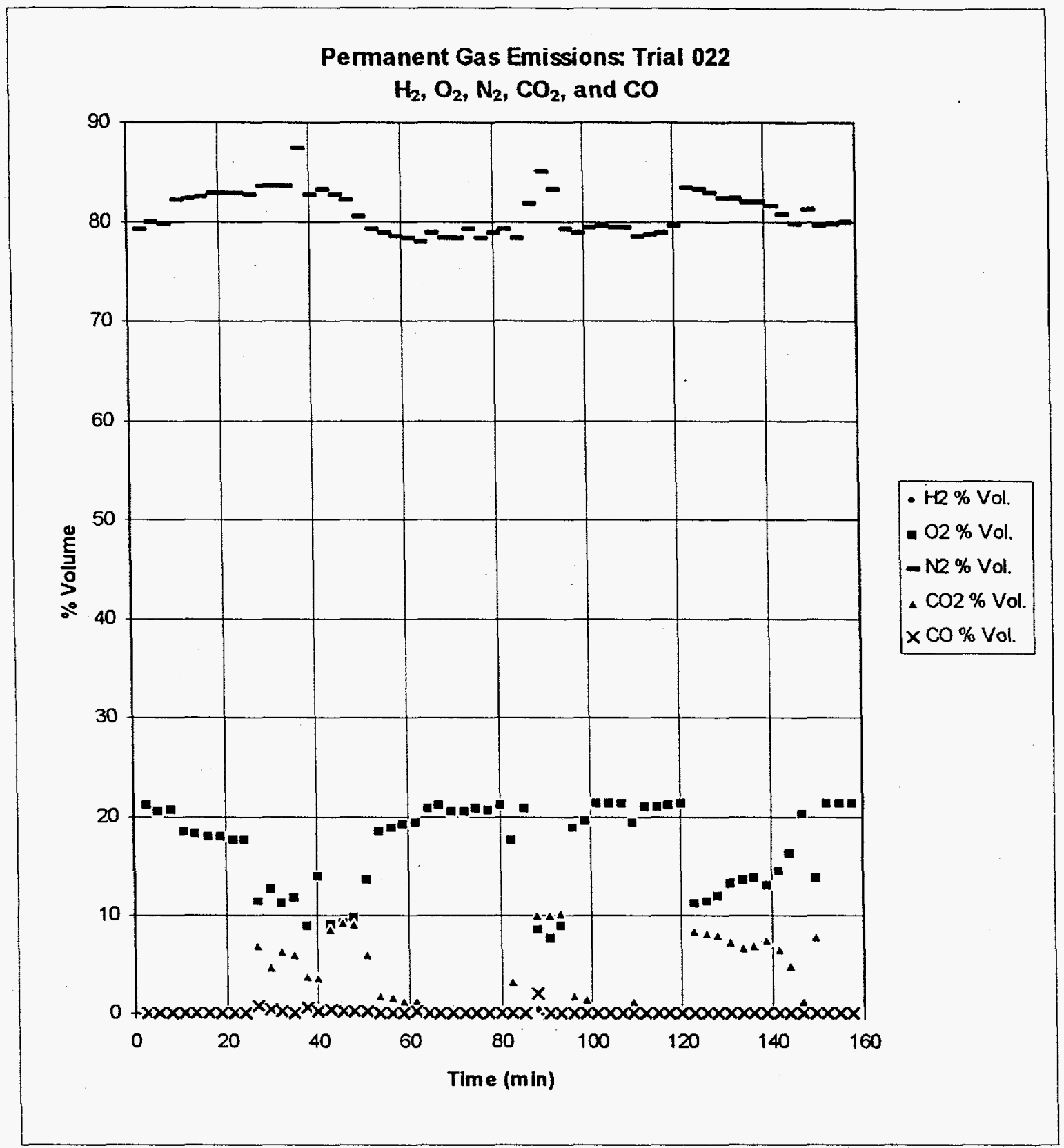

Figure 26. Offgas composition changes observed during Run \#8. (cont.) 


\section{Electrode Consumption}

Complete details of electrode weight loss are contained in Appendix. In summary, approximately equal upper electrode loss, as measured by weight $\%$ loss per $\mathrm{kWh}$, was observed for both the hollow (central hole) and modified (side holes) electrodes. This result is somewhat surprising given the increased surface area for air passage in the modified electrode, and the aggressive wear observed around the air exit holes during run 5 as shown in Figure 18. A review of the electrode wear data reveals that the hollow electrode suffers severe length loss compared to the modified electrode. While the hollow electrode lost an average of 0.6 inches $/ \mathrm{kWh}$, the modified electrode lost only $0.014 " / \mathrm{kWh}$ on average.

\section{CONCLUSIONS}

- Soil can be processed into a glassy, macroscopically homogeneous products in the graphite electrode, DC arc melter if air is injected into the melter during the run.

- Flux injection through a hollow (central hole) electrode results in frequent extinguishing of the arc.

- Flux injection through a modified (side holes) electrode does not extinguish the arc.

- Dolomitic lime was found to be the best flux for these trials based on its ability to be fed through the electrode without clogging, and its ability to enhance processing of the soil.

- Colemanite is not an acceptable flux for runs done under the conditions used in this study because it does not lower the viscosity of the melt or promote melting sufficiently to allow processing.

- lime used as a flux was adequate to promote processing of the soil for the conditions used in this study.

- When using lime as a flux, $70 \mathrm{kWh}$ energy input was sufficient for essentially complete processing.

- In terms of weight \% loss per $\mathrm{kWh}$ of power input to the melter, electrode geometry (central hole vs side holes) did not exert an influence on electrode wear.

- To attain essentially complete processing of the soils studied in this project typically required $4.2 \mathrm{kWh} / \mathrm{kg}$ of glass produced.

- Processing atmosphere within the vessel was very reducing despite injection of air during the run. 
- The processing atmosphere within the melter was very reducing despite air injection through the electrode. This resulted in offgas particulate matter emissions several orders of magnitude higher than typically observed within a joule-heated melter.

\section{RECOMMENDATIONS}

The graphite electrode, $\mathrm{DC}$ arc melter is capable of very high operating temperatures and, as a result, can consume a wide variety of objects that would not be destroyed in a traditional joule-heated melter. The reducing atmosphere that exists in the melter allows pyrolysis of high organic and debris-containing wastes without incineration. A subsequent transition to joule heating and an oxidizing atmosphere allows control over a wide range of melting temperatures and provides wide latitude for formation of stable glasses. Extinguishing the arc also quiets the melt pool., and is expected to diminish the release of particulate matter and potentially volatile constituents. Based on these observations, the following actions are recommended.

- Evaluate alternate electrodes, such as refractory metal or water non-consumable electrodes, to allow greater control over the reducing conditions existing in the melter.

- Further evaluate the transition from transferred arc to joule heating mode as a means of destroying debris and high organic materials followed by creation of a stable glass.

- Improve the offgas system to accommodate the potential creation of hazardous and flammable organic compounds.

- Explore the glass composition range that would be allowed by the wide temperature capability of the melter.

- Use the melter to do treatability studies on actual mixed waste streams.

\section{ACKNOWLEDGMENTS}

This research was funded by the United States Department of Energy in cooperation with the South Carolina Universities Research and Education Foundation (SCUREF) under Task Order 187. Technical oversight was provided by Dr. Andrea Kielpinski-Sadler. The colemanite used in this study was donated by OCF in Anderson, SC. 


\section{RECORDS}

This report is based on data contained in the following record books.

\begin{tabular}{|c|c|}
\hline Record Book & Pages \\
\hline AY & $76-78,80,83-87,89-90,96$ \\
\hline CG & $1-3,7-15,17-37,41-54$ \\
\hline $\mathrm{AX}$ & $19,20,29-39$ \\
\hline BW & $77-93$ \\
\hline $\mathrm{CI}$ & $1-16$ \\
\hline $\mathrm{CE}$ & 39,40 \\
\hline
\end{tabular}


Appendix A

Feed Compositions 


\begin{tabular}{|c|c|c|c|c|}
\hline Trial & Soil & Other & Flux & Total \\
\hline 014 & $\begin{array}{l}8.26 \mathrm{~kg} \text { SRS Clay Soil } \\
7.72 \mathrm{~kg} \text { SRS Sandy } \\
\text { Soil }\end{array}$ & $\begin{array}{l}0.173 \mathrm{~kg} \mathrm{Ce}\left(\mathrm{CO}_{3}\right)_{3} \\
0.253 \mathrm{~kg} \mathrm{Cu}\left(\mathrm{C}_{2} \mathrm{H}_{3} \mathrm{O}_{2}\right)_{2}\end{array}$ & $\begin{array}{l}8.02 \mathrm{~kg} \\
\text { Colemanite }\end{array}$ & $24.26 \mathrm{~kg}$ \\
\hline 015 & $\begin{array}{l}8.32 \mathrm{~kg} \text { SRS Clay Soil } \\
7.62 \mathrm{~kg} \text { SRS Sandy } \\
\text { Soil }\end{array}$ & $\begin{array}{l}0.172 \mathrm{~kg} \mathrm{Ce}\left(\mathrm{CO}_{3}\right)_{3} \\
0.262 \mathrm{~kg} \mathrm{Cu}\left(\mathrm{C}_{2} \mathrm{H}_{3} \mathrm{O}_{2}\right)_{2}\end{array}$ & $\begin{array}{l}7.02 \mathrm{~kg} \\
\text { Colemanite }\end{array}$ & $23.394 \mathrm{~kg}$ \\
\hline 016 & $\begin{array}{l}8.32 \mathrm{~kg} \text { SRS Clay Soil } \\
7.60 \mathrm{~kg} \text { SRS Sandy } \\
\text { Soil }\end{array}$ & $\begin{array}{l}0.172 \mathrm{~kg} \mathrm{Ce}\left(\mathrm{CO}_{3}\right)_{3} \\
0.262 \mathrm{~kg} \mathrm{Cu}\left(\mathrm{C}_{2} \mathrm{H}_{3} \mathrm{O}_{2}\right)_{2}\end{array}$ & $\begin{array}{l}7.02 \mathrm{~kg} \\
\text { Colemanite }\end{array}$ & $23.374 \mathrm{~kg}$ \\
\hline 017 & $\begin{array}{l}8.32 \mathrm{~kg} \text { SRS Clay Soil } \\
7.60 \mathrm{~kg} \text { SRS Sandy } \\
\text { Soil }\end{array}$ & $\begin{array}{l}0.170 \mathrm{~kg} \mathrm{Ce}\left(\mathrm{CO}_{3}\right)_{3} \\
0.262 \mathrm{~kg} \mathrm{Cu}\left(\mathrm{C}_{2} \mathrm{H}_{3} \mathrm{O}_{2}\right)_{2}\end{array}$ & $\begin{array}{l}8.96 \mathrm{~kg} \\
\text { Dolomitic } \\
\text { Limestone }\end{array}$ & $25.312 \mathrm{~kg}$ \\
\hline 018 & $\begin{array}{l}8.30 \mathrm{~kg} \text { SRS Clay Soil } \\
7.60 \mathrm{~kg} \text { SRS Sandy } \\
\text { Soil }\end{array}$ & $\begin{array}{l}0.172 \mathrm{~kg} \mathrm{Ce}\left(\mathrm{CO}_{3}\right)_{3} \\
0.267 \mathrm{~kg} \mathrm{Cu}\left(\mathrm{C}_{2} \mathrm{H}_{3} \mathrm{O}_{2}\right)_{2}\end{array}$ & $\begin{array}{l}8.96 \mathrm{~kg} \\
\text { Dolomitic } \\
\text { Limestone }\end{array}$ & $25.299 \mathrm{~kg}$ \\
\hline 020 & $\begin{array}{l}8.28 \mathrm{~kg} \text { SRS Clay Soil } \\
7.76 \mathrm{~kg} \text { SRS Sandy } \\
\text { Soil }\end{array}$ & $\begin{array}{l}0.177 \mathrm{~kg} \mathrm{Ce}_{2}\left(\mathrm{CO}_{3}\right)_{3} \\
0.261 \mathrm{~kg} \mathrm{Cu}\left(\mathrm{C}_{2} \mathrm{H}_{3} \mathrm{O}_{2}\right)_{2}\end{array}$ & $\begin{array}{l}6.74 \mathrm{~kg} \\
\mathrm{Ca}(\mathrm{OH})_{2}\end{array}$ & $23.218 \mathrm{~kg}$ \\
\hline 021 & $\begin{array}{l}15.50 \mathrm{~kg} \text { SRS Sandy } \\
\text { Soil }\end{array}$ & $\begin{array}{l}0.174 \mathrm{~kg} \mathrm{Ce}\left(\mathrm{CO}_{3}\right)_{3} \\
0.256 \mathrm{~kg} \mathrm{Cu}\left(\mathrm{C}_{2} \mathrm{H}_{3} \mathrm{O}_{2}\right)_{2}\end{array}$ & $\begin{array}{l}6.74 \mathrm{~kg} \\
\mathrm{Ca}(\mathrm{OH})_{2}\end{array}$ & $22.670 \mathrm{~kg}$ \\
\hline 022 & $\begin{array}{l}8.30 \mathrm{~kg} \text { SRS Clay Soil } \\
7.74 \mathrm{~kg} \text { SRS Sandy } \\
\text { Soil }\end{array}$ & $\begin{array}{l}0.174 \mathrm{~kg} \mathrm{Ce}\left(\mathrm{CO}_{3}\right)_{3} \\
0.258 \mathrm{~kg} \mathrm{Cu}\left(\mathrm{C}_{2} \mathrm{H}_{3} \mathrm{O}_{2}\right)_{2} \\
0.884 \mathrm{~kg} \text { steel disk } \\
0.152 \mathrm{~kg} \text { threaded rod } \\
1.430 \mathrm{~kg} \text { fiberglass } \\
\text { reinforced concrete }\end{array}$ & $\begin{array}{l}6.74 \mathrm{~kg} \\
\mathrm{Ca}(\mathrm{OH})_{2}\end{array}$ & $23.212 \mathrm{~kg}$ \\
\hline
\end{tabular}


Appendix B

Electrode Consumption 


\begin{tabular}{|c|c|c|c|c|c|c|}
\hline Trial & $\begin{array}{c}\text { Upper } \\
\text { Electrode } \\
\text { Before } \\
\end{array}$ & $\begin{array}{c}\text { Upper } \\
\text { Electrode } \\
\text { After }\end{array}$ & $\begin{array}{c}\text { Upper } \\
\text { Electrode } \\
\text { Loss } \\
\end{array}$ & $\begin{array}{c}\text { Lower } \\
\text { Electrode } \\
\text { Before }\end{array}$ & $\begin{array}{c}\text { Lower } \\
\text { Electrode } \\
\text { After } \\
\end{array}$ & $\begin{array}{l}\text { Lower } \\
\text { Electrode } \\
\text { Loss }\end{array}$ \\
\hline $\begin{array}{l}14 \\
\text { Diameter } \\
\text { Length } \\
\text { Mass } \\
29 \mathrm{kWh}\end{array}$ & $\begin{array}{l}\text { Standard } \\
\text { 3" } \\
21.0^{\prime \prime} \\
4.267 \mathrm{~kg}\end{array}$ & $\begin{array}{l}\text { 3" } \\
19.5 " \\
3.804 \mathrm{~kg} \\
0.052 " / \\
\mathrm{kWh}\end{array}$ & $\begin{array}{l}1.50 " \\
0.463 \mathrm{~kg}\end{array}$ & $\begin{array}{l}2 " \\
3.5^{\prime \prime} \\
0.351 \mathrm{~kg}\end{array}$ & $\begin{array}{l}2 " \\
\text { NA } \\
\text { NA }\end{array}$ & Run halted. \\
\hline $\begin{array}{l}015 \\
\text { Diameter } \\
\text { Length } \\
\text { Mass } \\
9 \mathrm{kWh}\end{array}$ & $\begin{array}{l}\text { Hollow } \\
3 " \\
22.0 " \\
\text { NA }\end{array}$ & $\begin{array}{l}3 " \\
22.0^{\prime \prime} \\
4.403 \mathrm{~kg}\end{array}$ & $\begin{array}{l}0 " \\
\text { NA }\end{array}$ & $\begin{array}{l}2 " \\
3.5 " \\
0.347 \mathrm{~kg}\end{array}$ & $\begin{array}{l}2 " \\
\text { NA } \\
\text { NA }\end{array}$ & $\begin{array}{l}\text { Two upper } \\
\text { electrodes } \\
\text { used. Both } \\
\text { snapped. Run } \\
\text { Halted }\end{array}$ \\
\hline $\begin{array}{l}016 \\
\text { Diameter } \\
\text { Length } \\
\text { Mass } \\
34 \mathrm{kWh}\end{array}$ & $\begin{array}{l}\text { Hollow } \\
3 " \\
22.0^{\prime \prime} \\
4.178 \mathrm{~kg}\end{array}$ & $\begin{array}{l}3 " \\
19.375 " \\
3.420 \mathrm{~kg} \\
0.07 " / \\
\mathrm{kWh}\end{array}$ & $\begin{array}{l}2.625^{\prime \prime} \\
0.758 \mathrm{~kg}\end{array}$ & $\begin{array}{l}2 " \\
2.375^{\prime \prime} \\
0.247 \mathrm{~kg}\end{array}$ & $\begin{array}{l}2 " \\
0 " \\
0 \mathrm{~kg}\end{array}$ & $\begin{array}{l}\text { Lower } \\
\text { Electrode } \\
\text { entirely } \\
\text { consumed. } \\
2.375^{\prime \prime} \\
0.247 \mathrm{~kg}\end{array}$ \\
\hline $\begin{array}{l}017 \\
\text { Diameter } \\
\text { Length } \\
\text { Mass } \\
22 \mathrm{kWh}\end{array}$ & $\begin{array}{l}\text { Modified } \\
\text { 3" } \\
18.875 " \\
3.540 \mathrm{~kg}\end{array}$ & $\begin{array}{l}3 " \\
\text { NA } \\
\text { NA }\end{array}$ & $\begin{array}{l}\text { NA } \\
\text { NA }\end{array}$ & $\begin{array}{l}2 " \\
3.0 " \\
0.317 \mathrm{~kg}\end{array}$ & $\begin{array}{l}2 " \\
\text { NA } \\
\text { NA }\end{array}$ & $\begin{array}{l}\text { Feed System } \\
\text { Clogged. Run } \\
\text { Halted. } \\
\text { NA } \\
\text { NA }\end{array}$ \\
\hline $\begin{array}{l}018 \\
\text { Diameter } \\
\text { Length } \\
\text { Mass } \\
70 \mathrm{kWh}\end{array}$ & $\begin{array}{l}\text { Modified } \\
\text { 3" } \\
20.375 " \\
3.619 \mathrm{~kg}\end{array}$ & $\begin{array}{l}3 " \\
19.75 " \\
2.853 \mathrm{~kg} \\
0.009 " / \\
\mathrm{kWh}\end{array}$ & $\begin{array}{l}0.625 " \\
0.766 \mathrm{~kg}\end{array}$ & $\begin{array}{l}2 " \\
2.0 " \\
0.229 \mathrm{~kg}\end{array}$ & $\begin{array}{l}2 " \\
0 " \\
0.072 \mathrm{~kg}\end{array}$ & $\begin{array}{l}2.0^{\prime \prime} \\
0.157 \mathrm{~kg}\end{array}$ \\
\hline
\end{tabular}




\begin{tabular}{|c|c|c|c|c|c|c|}
\hline Trial & $\begin{array}{c}\text { Upper } \\
\text { Electrode } \\
\text { Before }\end{array}$ & $\begin{array}{c}\text { Upper } \\
\text { Electrode } \\
\text { After }\end{array}$ & Loss & $\begin{array}{c}\text { Lower } \\
\text { Electrode } \\
\text { Before }\end{array}$ & $\begin{array}{c}\text { Lower } \\
\text { Electrode } \\
\text { After }\end{array}$ & Loss \\
\hline $\begin{array}{l}020 \\
\text { Diameter } \\
\text { Length } \\
\text { Mass } \\
70 \mathrm{kWh}\end{array}$ & $\begin{array}{l}\text { Modified } \\
3 " \\
16.875^{\prime \prime} \\
3.039 \mathrm{~kg}\end{array}$ & $\begin{array}{l}3 " \\
16.125 " \\
2.339 \mathrm{~kg} \\
0.011 " / \\
\mathrm{kWh}\end{array}$ & $\begin{array}{l}0.75 " \\
0.7 \mathrm{~kg}\end{array}$ & $\begin{array}{l}2 " \\
2.438 " \\
0.554 \mathrm{~kg}\end{array}$ & $\begin{array}{l}2 " \\
0.75^{\prime \prime} \\
0.090 \mathrm{~kg}\end{array}$ & $\begin{array}{l}1.688^{\prime \prime} \\
0.464 \mathrm{~kg}\end{array}$ \\
\hline $\begin{array}{l}021 \\
\text { Diameter } \\
\text { Length } \\
\text { Mass } \\
64 \mathrm{kWh}\end{array}$ & $\begin{array}{l}\text { Modified } \\
\text { 3" } \\
20.563 " \\
3.742 \mathrm{~kg}\end{array}$ & $\begin{array}{l}3 " \\
19.75 " \\
3.036 \mathrm{~kg} \\
0.013 " / \\
\mathrm{kWh}\end{array}$ & $\begin{array}{l}0.813 " \\
0.706 \mathrm{~kg}\end{array}$ & $\begin{array}{l}2 " \\
3.313 " \\
0.335 \mathrm{~kg}\end{array}$ & $\begin{array}{l}2 " \\
1.0 " \\
0.135 \mathrm{~kg}\end{array}$ & $\begin{array}{l}2.313 " \\
0.20 \mathrm{~kg}\end{array}$ \\
\hline $\begin{array}{l}022 \\
\text { Diameter } \\
\text { Length } \\
\text { Mass } \\
70 \mathrm{kWh}\end{array}$ & $\begin{array}{l}\text { Modified } \\
\text { 3" } \\
20.563 " \\
3.727 \mathrm{~kg}\end{array}$ & $\begin{array}{l}3 " \\
19.0 " \\
2.757 \mathrm{~kg} \\
0.022 " / \\
\mathrm{kWh}\end{array}$ & $\begin{array}{l}1.563 " \\
0.970 \mathrm{~kg}\end{array}$ & $\begin{array}{l}2 " \\
2.875^{\prime \prime} \\
0.296 \mathrm{~kg}\end{array}$ & $\begin{array}{l}\text { 2" } \\
0 " \\
0 \mathrm{~kg}\end{array}$ & $\begin{array}{l}2.875^{\prime \prime} \\
0.296 \mathrm{~kg}\end{array}$ \\
\hline
\end{tabular}




\section{Appendix C}

Permanent Gas Analysis Results (Runs 1-8) 
Permanent Gas

Analyses

Run \#1 4/9/96

\begin{tabular}{|c|c|c|c|c|c|c|c|}
\hline Sample & $\begin{array}{l}\text { Cycle } \\
\text { Time } \\
\text { (min) }\end{array}$ & \begin{tabular}{|c|} 
Run Time \\
(min)
\end{tabular} & $\begin{array}{c}\mathrm{H}_{2} \\
\% \text { Vol. }\end{array}$ & $\begin{array}{c}\mathrm{O}_{2} \\
\% \text { Vol. }\end{array}$ & $\begin{array}{c}\mathrm{N}_{2} \\
\% \text { Vol. }\end{array}$ & $\begin{array}{c}\mathrm{CO}_{2} \\
\% \mathrm{Vol} .\end{array}$ & $\mathrm{CO}$ \\
\hline 1 & 2.5 & 2.5 & 0.094 & 20.946 & 78.324 & 0.350 & No \\
\hline 2 & 2.5 & 5.0 & 0.010 & 20.574 & 78.644 & 0.330 & No \\
\hline 3 & 2.5 & 7.5 & 0.003 & 20.540 & 78.418 & 0.290 & No \\
\hline 4 & 2.5 & 10.0 & 0.002 & 20.625 & 78.494 & 0.285 & No \\
\hline 5 & 2.5 & 12.5 & 0.001 & 20.743 & 78.456 & 0.276 & No \\
\hline 6 & 2.5 & 15.0 & 0.001 & 20.803 & 78.281 & 0.260 & No \\
\hline 7 & 2.5 & 17.5 & 0.001 & 20.815 & 78.236 & 0.213 & No \\
\hline 8 & 2.5 & 20.0 & 0.000 & 20.821 & 78.138 & 0.272 & No \\
\hline 9 & 2.5 & 22.5 & 0.000 & 20.837 & 78.113 & 0.177 & No \\
\hline 10 & 2.5 & 25.0 & 0.210 & 17.275 & 77.860 & 2.891 & No \\
\hline 11 & 2.5 & 27.5 & 0.262 & 15.786 & 77.257 & 4.390 & Yes \\
\hline 12 & 2.5 & 30.0 & 1.133 & 18.194 & 75.374 & 2.209 & Yes \\
\hline 13 & 2.5 & 32.5 & 0.566 & 15.848 & 76.219 & 4.416 & Yes \\
\hline 14 & 2.5 & 35.0 & 0.318 & 15.736 & 76.428 & 4.930 & Yes \\
\hline 15 & 2.5 & 37.5 & 0.447 & 16.424 & 75.547 & 4.549 & Yes \\
\hline 16 & 2.5 & 40.0 & 0.279 & 15.684 & 75.193 & 5.836 & Yes \\
\hline 17 & 2.833 & 42.8 & 0.279 & 15.158 & 74.779 & 6.515 & Yes \\
\hline 18 & 2.5 & 45.3 & 0.313 & 13.945 & 74.636 & 7.639 & Yes \\
\hline 19 & 2.5 & 47.8 & 0.225 & 11.875 & 74.593 & 9.556 & Yes \\
\hline 20 & 3.333 & 51.2 & 0.137 & 10.813 & 74.406 & 11.228 & No \\
\hline 21 & 3.0 & 54.2 & 0.159 & 7.970 & 75.038 & 12.616 & No \\
\hline 22 & 3.0 & 57.2 & 0.044 & 6.187 & 75.935 & 13.708 & No \\
\hline 23 & 3.0 & 60.2 & 0.085 & 5.200 & 76.380 & 13.898 & No \\
\hline 24 & 3.0 & 63.2 & 0.034 & 4.608 & 76.422 & 14.286 & No \\
\hline 25 & 3.0 & 66.2 & 0.014 & 4.835 & 76.590 & 14.361 & No \\
\hline 26 & 3.0 & 69.2 & 0.012 & 4.341 & 76.564 & 14.456 & No \\
\hline 27 & 3.0 & 72.2 & 0.037 & 2.932 & 77.098 & 14.923 & No \\
\hline 28 & 3.0 & 75.2 & 0.039 & 2.480 & 77.035 & 15.479 & No \\
\hline 29 & 3.0 & 78.2 & 0.059 & 2.439 & 77.198 & 15.141 & No \\
\hline 30 & 3.0 & 81.2 & 0.201 & 1.273 & 76.919 & 16.170 & No \\
\hline 31 & 3.0 & 84.2 & 0.254 & 1.160 & 76.541 & 16.378 & No \\
\hline 32 & 3.0 & 87.2 & 0.102 & 1.996 & 76.516 & 16.230 & No \\
\hline 33 & 3.0 & 90.2 & 0.502 & 1.231 & 76.314 & 16.134 & No \\
\hline 34 & 3.0 & 93.2 & 0.861 & 0.798 & 75.363 & 16.211 & Yes \\
\hline 35 & 3.0 & 96.2 & 0.511 & 4.155 & 75.525 & 14.096 & No \\
\hline
\end{tabular}


Permanent Gas

Analyses

Run \#1 4/9/96

\begin{tabular}{|c|c|c|c|c|c|c|c|}
\hline Sample & $\begin{array}{c}\text { Cycle } \\
\text { Time } \\
(\mathrm{min})\end{array}$ & Run Time & $\mathrm{H}_{2}$ & $\mathrm{O}_{2}$ & $\mathrm{~N}_{2}$ & $\mathrm{CO}_{2}$ & $\mathrm{CO}$ \\
\hline 36 & 3.0 & 99.2 & 0.159 & 12.907 & 76.402 & 7.366 & No \\
\hline 37 & 3.0 & 102.2 & 0.086 & 16.555 & 76.902 & 4.182 & No \\
\hline 38 & 3.0 & 105.2 & 0.083 & 17.616 & 76.990 & 3.088 & No \\
\hline 39 & 3.0 & 108.2 & 0.089 & 18.100 & 77.083 & 2.487 & No \\
\hline 40 & 3.0 & 111.2 & 0.097 & 17.922 & 77.137 & 2.578 & No \\
\hline 41 & 3.0 & 114.2 & 0.124 & 18.019 & 77.094 & 2.515 & No \\
\hline 42 & 3.0 & 117.2 & 0.172 & 17.628 & 77.102 & 2.812 & No \\
\hline 43 & 3.0 & 120.2 & 0.278 & 17.597 & 76.879 & 2.785 & No \\
\hline 44 & 3.0 & 123.2 & 0.312 & 18.071 & 76.643 & 2.114 & No \\
\hline 45 & 3.0 & 126.2 & 0.352 & 18.202 & 76.530 & 2.012 & No \\
\hline 46 & 3.0 & 129.2 & 0.454 & 18.079 & 76.460 & 2.176 & No \\
\hline
\end{tabular}




\begin{tabular}{|c|c|c|c|c|c|c|c|}
\hline $\begin{array}{l}\text { Run \#2 } \\
\text { Raw } \\
\text { Data }\end{array}$ & $4 / 19 / 96$ & & & & & & \\
\hline Sample & $\begin{array}{l}\text { Cycle } \\
\text { Time } \\
\text { (min) }\end{array}$ & $\begin{array}{c}\text { Run Time } \\
\text { (min) }\end{array}$ & $\begin{array}{c}\mathrm{H}_{2} \\
\% \text { Vol. }\end{array}$ & $\begin{array}{c}\mathrm{O}_{2} \\
\% \text { Vol. }\end{array}$ & $\begin{array}{c}\mathrm{N}_{2} \\
\% \text { Vol. }\end{array}$ & $\begin{array}{c}\mathrm{CO}_{2} \\
\% \mathrm{Vol}\end{array}$ & $\begin{array}{l}\text { Total } \\
\% \text { Vol. }\end{array}$ \\
\hline 1 & 3 & 3.0 & 0.121 & 19.868 & 79.562 & 0.172 & 99.723 \\
\hline 2 & 3 & 6.0 & 0.018 & 12.628 & 87.629 & 0.052 & 100.327 \\
\hline 3 & 3 & 9.0 & 0.006 & 11.606 & 88.557 & 0.031 & 100.2 \\
\hline 4 & 3 & 12.0 & 0.003 & 10.896 & 89.488 & 0.027 & 100.414 \\
\hline 5 & 3 & 15.0 & 0.003 & 13.335 & 86.535 & 0.031 & 99.904 \\
\hline 6 & 3 & 18.0 & 0.001 & 13.784 & 86.091 & 0.031 & 99.907 \\
\hline 7 & 3 & 21.0 & 0.328 & 12.505 & 86.134 & 0.575 & 99.542 \\
\hline 8 & 3 & 24.0 & 0.273 & 12.972 & 85.353 & 0.65 & 99.248 \\
\hline 9 & 3 & 27.0 & 0.603 & 13.195 & 84.293 & 0.887 & 98.978 \\
\hline 10 & 3 & 30.0 & 1.03 & 12.662 & 84.361 & 1.359 & 99.412 \\
\hline 11 & 3 & 33.0 & 0.566 & 12.511 & 84.306 & 1.746 & 99.129 \\
\hline 12 & 3 & 36.0 & 0.335 & 10.955 & 84.906 & 3.303 & 99.499 \\
\hline 13 & 3 & 39.0 & 0.231 & 8.55 & 85.562 & 5.423 & 99.766 \\
\hline 14 & 3 & 42.0 & 0.158 & 10.872 & 83.242 & 5.547 & 99.819 \\
\hline 15 & 3 & 45.0 & 0.204 & 7.705 & 85.637 & 6.243 & 99.789 \\
\hline 16 & 3 & 48.0 & 0.195 & 6.423 & 84.739 & 8.626 & 99.983 \\
\hline 17 & 3 & 51.0 & 0.092 & 6.736 & 83.886 & 9.388 & 100.102 \\
\hline 18 & 3 & 54.0 & 0.047 & 7.133 & 84.942 & 7.69 & 99.812 \\
\hline 19 & 3 & 57.0 & 0.035 & 9.338 & 83.618 & 6.723 & 99.714 \\
\hline 20 & 3 & 60.0 & 0.035 & 7.689 & 85.062 & 7.152 & 99.938 \\
\hline 21 & 3 & 63.0 & 0.027 & 7.248 & 84.236 & 7.393 & 98.904 \\
\hline 22 & 3 & 66.0 & 0.099 & 8.677 & 82.695 & 7.448 & 98.919 \\
\hline 23 & 3 & 69.0 & 0.119 & 10.794 & 83.339 & 4.308 & 98.56 \\
\hline 24 & 3 & 72.0 & 0.082 & 12.465 & 84.826 & 1.406 & 98.779 \\
\hline 25 & 3 & 75.0 & .0 .063 & 13.02 & 84.984 & 0.786 & 98.853 \\
\hline
\end{tabular}




\begin{tabular}{|c|c|c|c|c|c|c|c|}
\hline $\begin{array}{l}\text { Run \#3 } \\
\text { Raw } \\
\text { Data }\end{array}$ & $4 / 23 / 96$ & & & & & & \\
\hline Sample & $\begin{array}{l}\text { Cycle } \\
\text { Time } \\
\text { (min) }\end{array}$ & $\begin{array}{c}\text { Run Time } \\
(\min )\end{array}$ & $\begin{array}{c}\mathrm{H}_{2} \\
\% \text { Vol. }\end{array}$ & $\begin{array}{c}\mathrm{O}_{2} \\
\% \text { Vol. }\end{array}$ & $\begin{array}{c}\mathrm{N}_{2} \\
\% \text { Vol. }\end{array}$ & $\begin{array}{c}\mathrm{CO}_{2} \\
\% \mathrm{Vol}\end{array}$ & $\begin{array}{l}\text { Total } \\
\% \text { Vol. }\end{array}$ \\
\hline 1 & 3 & 3.0 & 0.006 & 17.101 & 80.075 & 0.057 & 97.239 \\
\hline 2 & 3 & 6.0 & 0.004 & 16.755 & 80.233 & 0.057 & 97.049 \\
\hline 3 & 3 & 9.0 & 0.003 & 15.632 & 81.163 & 0.037 & 96.835 \\
\hline 4 & 3 & 12.0 & 0.002 & 14.421 & 82.47 & 0.033 & 96.926 \\
\hline 5 & 3 & 15.0 & 0.001 & 13.583 & 83.243 & 0.03 & 96.857 \\
\hline 6 & 3 & 18.0 & 0.001 & 13.744 & 82.963 & 0.03 & 96.738 \\
\hline 7 & 3 & 21.0 & 0.141 & 11.811 & 83.266 & 1.142 & 96.36 \\
\hline 8 & 3 & 24.0 & 0.299 & 10.792 & 82.209 & 2.617 & 95.917 \\
\hline 9 & 3 & 27.0 & 0.43 & 10.631 & 81.471 & 3.17 & 95.702 \\
\hline 10 & 3 & 30.0 & 0.575 & 9.363 & 81.18 & 4.241 & 95.359 \\
\hline 11 & 3 & 33.0 & 0.339 & 8.901 & 81.655 & 4.995 & 95.89 \\
\hline 12 & 3 & 36.0 & 0.165 & 8.628 & 81.541 & 5.889 & 96.223 \\
\hline 13 & 3 & 39.0 & 0.067 & 6.451 & 81.736 & 8.144 & 96.398 \\
\hline 14 & 3 & 42.0 & 0.03 & 3.278 & 80.896 & 12.543 & 96.747 \\
\hline 15 & 3 & 45.0 & 0.079 & 2.775 & 80.183 & 13.799 & 96.836 \\
\hline 16 & 3 & 48.0 & 0.294 & 1.023 & 79.759 & 15.153 & 96.229 \\
\hline 17 & 3 & 51.0 & 0.299 & 0.642 & 79.251 & 16.294 & 96.486 \\
\hline 18 & 3 & 54.0 & 1.833 & 0.425 & 77.373 & 14.484 & 94.115 \\
\hline 19 & 3 & 57.0 & 2.598 & 0.208 & 76.586 & 12.816 & 92.208 \\
\hline 20 & 3 & 60.0 & 2.857 & 0.222 & 75.809 & 12.765 & 91.653 \\
\hline 21 & 3 & 63.0 & 2.546 & 0.383 & 77.705 & 12.612 & 93.246 \\
\hline 22 & 3 & 66.0 & 2.88 & 0.525 & 77.527 & 11.736 & 92.668 \\
\hline 23 & 3 & 69.0 & 1.665 & 0.361 & 79.347 & 13.101 & 94.474 \\
\hline 24 & 3 & 72.0 & 2.072 & 0.254 & 78.134 & 13.765 & 94.225 \\
\hline 25 & 3 & 75.0 & 2.014 & 0.163 & 77.748 & 13.848 & 93.773 \\
\hline 26 & 3 & 78.0 & 1.389 & 0.185 & 78.158 & 14.89 & 94.622 \\
\hline 27 & 3 & 81.0 & 1.254 & 0.291 & 78.92 & 14.282 & 94.747 \\
\hline 28 & 3 & 84.0 & 0.524 & 1.129 & 80.132 & 14.369 & 96.154 \\
\hline 29 & 3 & 87.0 & 0.431 & 2.667 & 80.447 & 13.193 & 96.738 \\
\hline 30 & 3 & 90.0 & 0.324 & 1.662 & 80.466 & 13.957 & 96.409 \\
\hline 31 & 3 & 93.0 & 0.086 & 2.609 & 80.623 & 14.078 & 97.396 \\
\hline 32 & 3 & 96.0 & 0.053 & 2.839 & 80.651 & 13.849 & 97.392 \\
\hline 33 & 3 & 99.0 & 0.026 & 3.631 & 80.849 & 13.009 & 97.515 \\
\hline 34 & 3 & 102.0 & 0.885 & 1.388 & 78.207 & 13.81 & 94.29 \\
\hline 35 & 3 & 105.0 & 0.714 & 0.564 & 77.966 & 15.049 & 94.293 \\
\hline 36 & 3 & 108.0 & 0.374 & 2.308 & 80.116 & 13.309 & 96.107 \\
\hline 37 & 3 & 111.0 & 0.437 & 1.91 & 81.03 & 12.782 & 96.159 \\
\hline
\end{tabular}




\begin{tabular}{|l|c|c|c|c|c|c|c||}
\hline $\begin{array}{l}\text { Run \#3 } \\
\text { Raw } \\
\text { Data }\end{array}$ & $4 / 23 / 96$ & & & & & & \\
\hline Sample & $\begin{array}{c}\text { Cycle } \\
\text { Time } \\
(\mathrm{min})\end{array}$ & $\begin{array}{c}\text { Run Time } \\
(\mathrm{min})\end{array}$ & $\mathrm{H}_{2}$ & $\mathrm{O}_{2}$ & $\mathrm{~N}_{2}$ & $\mathrm{CO}_{2}$ & Total \\
$\%$ Vol. & $\%$ Vol. & $\%$ Vol. & $\%$ Vol. \\
\hline 38 & 3 & 114.0 & 0.209 & 3.226 & 80.714 & 12.381 & 96.53 \\
\hline 39 & 3 & 117.0 & 0.061 & 7.999 & 81.65 & 7.263 & 96.973 \\
\hline 40 & 3 & 120.0 & 0.043 & 10.299 & 82.183 & 3.999 & 96.524 \\
\hline 41 & 3 & 123.0 & 0.042 & 11.749 & 81.839 & 2.708 & 96.338 \\
\hline 42 & 3 & 126.0 & 0.046 & 12.269 & 81.98 & 1.984 & 96.279 \\
\hline 43 & 3 & 129.0 & 0.049 & 11.783 & 83.02 & 1.533 & 96.385 \\
\hline 44 & 3 & 132.0 & 0.043 & 13.082 & 81.918 & 1.187 & 96.23 \\
\hline 45 & 3 & 135.0 & 0.038 & 16.192 & 78.71 & 0.926 & 95.866 \\
\hline 46 & 3 & 138.0 & 0.037 & 18.432 & 77.39 & 0.885 & 96.744 \\
\hline
\end{tabular}




\begin{tabular}{|c|c|c|c|c|c|c|c|c||}
\hline $\begin{array}{c}\text { Run \#4 } \\
\text { Raw Data }\end{array}$ & $4 / 23 / 96$ & & & & & & & \\
\hline Sample & $\begin{array}{c}\text { Cycle } \\
\text { Time } \\
(\mathrm{min})\end{array}$ & Run Time & $\mathrm{H}_{2}$ & $\mathrm{O}_{2}$ & $\mathrm{~N}_{2}$ & $\mathrm{CO}_{2}$ & $\mathrm{CO}$ & Total \\
$\%$ Vol. & $\%$ Vol. & $\%$ Vol. & $\%$ Vol. & $\%$ Vol. & $\%$ Vol. \\
\hline 39 & 2.5 & 97.5 & 0.058 & 13.915 & 82.506 & 1.991 & 0.118 & 98.588 \\
\hline 40 & 2.5 & 100.0 & 0.048 & 14.428 & 82.579 & 1.442 & 0.04 & 98.537 \\
\hline 41 & 2.5 & 102.5 & 0.046 & 14.255 & 82.992 & 1.169 & 0.032 & 98.494 \\
\hline 42 & 2.5 & 105.0 & 0.039 & 14.392 & 83.037 & 0.94 & 0.024 & 98.432 \\
\hline
\end{tabular}




\begin{tabular}{|c|c|c|c|c|c|c|c|c|}
\hline $\begin{array}{l}\text { Run \#5 } \\
\text { Raw } \\
\text { Data }\end{array}$ & $4 / 30 / 96$ & & & & & & & \\
\hline Sample & $\begin{array}{l}\text { Cycle } \\
\text { Time } \\
\text { (min) }\end{array}$ & $\begin{array}{c}\text { Run Time } \\
\text { (min) }\end{array}$ & $\begin{array}{c}\mathrm{H}_{2} \\
\text { \% Vol. }\end{array}$ & $\begin{array}{c}\mathrm{O}_{2} \\
\% \text { Vol. }\end{array}$ & $\begin{array}{c}\mathrm{N}_{2} \\
\% \text { Vol. }\end{array}$ & $\begin{array}{c}\mathrm{CO}_{2} \\
\% \mathrm{Vol}\end{array}$ & $\begin{array}{c}\mathrm{CO} \\
\% \text { Vol. }\end{array}$ & $\begin{array}{l}\text { Total } \\
\% \text { Vol. }\end{array}$ \\
\hline 1 & 2.5 & 2.5 & 0.151 & 20.764 & 78.058 & 0.197 & 0.000 & 99.17 \\
\hline 2 & 2.5 & 5.0 & 0.012 & 20.901 & 78.095 & 0.043 & 0.000 & 99.051 \\
\hline 3 & 2.5 & 7.5 & 0.000 & 20.963 & 78.228 & 0.034 & 0.000 & 99.225 \\
\hline 4 & 2.5 & 10.0 & 0.000 & 19.172 & 79.719 & 0.106 & 0.000 & 98.997 \\
\hline 5 & 2.5 & 12.5 & 0.000 & 17.235 & 81.719 & 0.078 & 0.000 & 99.032 \\
\hline 6 & 2.5 & 15.0 & 0.000 & 16.988 & 81.784 & 0.056 & 0.000 & 98.828 \\
\hline 7 & 2.5 & 17.5 & 0.000 & 16.843 & 81.940 & 0.052 & 0.000 & 98.835 \\
\hline 8 & 2.5 & 20.0 & 0.000 & 16.620 & 81.601 & 0.050 & 0.000 & 98.271 \\
\hline 9 & 2.5 & 22.5 & 0.003 & 16.073 & 82.106 & 0.054 & 0.000 & 98.236 \\
\hline 10 & 2.5 & 25.0 & 0.000 & 15.902 & 82.322 & 0.046 & 0.000 & 98.27 \\
\hline 11 & 2.5 & 27.5 & 0.168 & 14.334 & 80.394 & 2.536 & 0.572 & 98.004 \\
\hline 12 & 2.5 & 30.0 & 0.201 & 14.516 & 80.409 & 1.817 & 0.708 & $97.651=$ \\
\hline 13 & 2.5 & 32.5 & 0.444 & 12.453 & 77.486 & 5.474 & 1.991 & 97.848 \\
\hline 14 & 2.5 & 35.0 & 0.344 & 11.779 & 76.158 & 7.617 & 2.079 & 97.977 \\
\hline 15 & 2.5 & 37.5 & 0.148 & 11.716 & 77.863 & 7.395 & 0.797 & 97.919 \\
\hline 16 & 2.5 & 40.0 & 0.078 & 10.644 & 77.831 & 8.958 & 0.408 & 97.919 \\
\hline 17 & 2.5 & 42.5 & 0.100 & 8.937 & 74.048 & 14.096 & 0.987 & 98.168 \\
\hline 18 & 2.5 & 45.0 & 0.177 & 7.277 & 70.477 & 18.743 & 1.485 & 98.159 \\
\hline 19 & 2.5 & 47.5 & 0.091 & 6.352 & 71.123 & 19.234 & 0.769 & 97.569 \\
\hline 20 & 2.5 & 50.0 & 0.037 & 7.298 & 73.595 & 16.911 & 0.233 & 98.074 \\
\hline 21 & 2.5 & 52.5 & 0.049 & 6.645 & 72.839 & 17.387 & 0.395 & 97.315 \\
\hline 22 & 2.5 & 55.0 & 0.036 & 6.052 & 72.894 & 18.543 & 0.326 & 97.851 \\
\hline 23 & 2.5 & 57.5 & 0.012 & 6.784 & 75.128 & 16.212 & 0.110 & 98.246 \\
\hline 24 & 2.5 & 60.0 & 0.009 & 6.893 & 75.751 & 15.281 & 0.074 & 98.008 \\
\hline 25 & 2.5 & 62.5 & 0.005 & 7.983 & 76.390 & 13.552 & 0.049 & 97.979 \\
\hline 26 & 2.5 & 65.0 & 0.003 & 7.720 & 75.260 & 14.794 & 0.036 & 97.813 \\
\hline 27 & 2.5 & 67.5 & 0.004 & 7.570 & 74.603 & 15.681 & 0.057 & 97.915 \\
\hline 28 & 2.5 & 70.0 & 0.003 & 7.625 & 71.834 & 18.396 & 0.073 & 97.931 \\
\hline 29 & 2.5 & 72.5 & 0.002 & 7.619 & 72.495 & 17.714 & 0.061 & 97.891 \\
\hline 30 & 2.5 & 75.0 & 0.002 & 8.105 & 73.594 & 16.110 & 0.057 & 97.868 \\
\hline 31 & 2.5 & 77.5 & 0.001 & 8.159 & 73.275 & 16.218 & 0.045 & 97.698 \\
\hline 32 & 2.5 & 80.0 & 0.002 & 8.091 & 73.729 & 16.213 & 0.050 & 98.085 \\
\hline 33 & 2.5 & 82.5 & 0.000 & 19.539 & 76.412 & 1.221 & 0.000 & 97.172 \\
\hline 34 & 2.5 & 85.0 & 0.000 & 20.419 & 76.558 & 0.116 & 0.000 & 97.093 \\
\hline 35 & 2.5 & 87.5 & 0.000 & 13.338 & 75.495 & 8.133 & 0.028 & 96.994 \\
\hline 36 & 2.5 & 90.0 & 0.000 & 9.252 & 74.647 & 12.987 & 0.039 & 96.925 \\
\hline 37 & 2.5 & 92.5 & 0.000 & 7.724 & 74.018 & 15.472 & 0.038 & 97.252 \\
\hline
\end{tabular}




\begin{tabular}{||c|c|c|c|c|c|c|c|c||}
\hline $\begin{array}{l}\text { Run \#5 } \\
\text { Raw } \\
\text { Data }\end{array}$ & $4 / 30 / 96$ & & & & & & \\
\hline Sample & $\begin{array}{c}\text { Cycle } \\
\text { Time } \\
(\text { min) }\end{array}$ & Run Time & $\mathrm{H}_{2}$ & $\mathrm{O}_{2}$ & $\mathrm{~N}_{2}$ & $\mathrm{CO}_{2}$ & $\mathrm{CO}$ & Total \\
\hline 38 & 2.5 & 95.0 & 0.000 & 6.743 & 71.635 & 19.045 & 0.038 & 97.461 \\
\hline 39 & 2.5 & 97.5 & 0.000 & 6.959 & 72.477 & 18.139 & 0.028 & 97.603 \\
\hline 40 & 2.5 & 100.0 & 0.000 & 5.592 & 71.546 & 19.518 & 0.027 & 96.683 \\
\hline 41 & 2.5 & 102.5 & 0.000 & 5.197 & 71.183 & 20.285 & 0.028 & 96.693 \\
\hline 42 & 2.5 & 105.0 & 0.000 & 4.918 & 70.370 & 21.455 & 0.000 & 96.743 \\
\hline 43 & 2.5 & 107.5 & 0.000 & 5.300 & 70.951 & 20.343 & 0.000 & 96.594 \\
\hline 44 & 2.5 & 110.0 & 0.000 & 6.483 & 72.619 & 17.951 & 0.019 & 97.072 \\
\hline 45 & 2.5 & 112.5 & 0.000 & 6.655 & 74.541 & 15.891 & 0.021 & 97.108 \\
\hline 46 & 2.5 & 115.0 & 0.000 & 6.790 & 75.425 & 14.685 & 0.017 & 96.917 \\
\hline 47 & 2.5 & 117.5 & 0.000 & 6.267 & 75.831 & 14.747 & 0.000 & 96.845 \\
\hline 48 & 2.5 & 120.0 & 0.000 & 5.849 & 75.541 & 15.333 & 0.000 & 96.723 \\
\hline 49 & 2.5 & 122.5 & 0.000 & 17.845 & 76.391 & 2.946 & 0.000 & 97.182 \\
\hline 50 & 2.5 & 125.0 & 0.000 & 20.329 & 76.460 & 0.161 & 0.000 & 96.95 \\
\hline 51 & 2.5 & 127.5 & 0.000 & 20.364 & 76.356 & 0.088 & 0.000 & 96.808 \\
\hline 52 & 2.5 & 130.0 & 0.000 & 17.077 & 75.977 & 2.694 & 0.000 & 95.748 \\
\hline 53 & 2.5 & 132.5 & 0.000 & 7.110 & 76.426 & 12.568 & 0.000 & 96.104 \\
\hline 54 & 2.5 & 135.0 & 0.000 & 5.759 & 76.835 & 13.456 & 0.000 & 96.05 \\
\hline
\end{tabular}


Trial $020 \quad 5 / 9 / 96$

Raw Data Run \#6

\begin{tabular}{|c|c|c|c|c|c|c|c|c|}
\hline Sample & $\begin{array}{l}\text { Cycle } \\
\text { Time } \\
\text { (min) }\end{array}$ & $\begin{array}{c}\text { Run Time } \\
\text { (min) }\end{array}$ & $\begin{array}{c}\mathrm{H}_{2} \\
\% \mathrm{Vol}\end{array}$ & $\begin{array}{c}\mathrm{O}_{2} \\
\% \text { Vol. }\end{array}$ & $\begin{array}{c}\mathrm{N}_{2} \\
\% \mathrm{Vol} .\end{array}$ & $\begin{array}{c}\mathrm{CO}_{2} \\
\% \text { Vol. }\end{array}$ & $\begin{array}{c}\mathrm{CO} \\
\% \mathrm{Vol}\end{array}$ & $\begin{array}{l}\text { Total } \\
\% \text { Vol. }\end{array}$ \\
\hline 1.000 & 2.500 & 2.500 & 0.027 & 17.687 & 81.569 & 0.045 & 0.000 & 99.328 \\
\hline 2.000 & 2.500 & 5.000 & 0.006 & 17.513 & 81.408 & 0.035 & 0.000 & 98.962 \\
\hline 3.000 & 2.500 & 7.500 & 0.002 & 17.078 & 81.612 & 0.036 & 0.000 & 98.728 \\
\hline 4.000 & 2.500 & 10.000 & 0.001 & 16.949 & 81.828 & 0.033 & 0.000 & 98.811 \\
\hline 5.000 & 2.500 & 12.500 & 0.000 & \begin{tabular}{|l|}
16.946 \\
\end{tabular} & 81.959 & 0.034 & 0.000 & 98.939 \\
\hline 6.000 & 2.500 & 15.000 & 0.070 & 16.384 & 82.276 & 0.124 & 0.030 & 98.884 \\
\hline 7.000 & 2.500 & 17.500 & 0.092 & 15.617 & 81.984 & 0.588 & 0.162 & 98.443 \\
\hline 8.000 & 2.500 & 20.000 & 1.314 & 9.462 & 81.001 & 4.995 & 1.983 & 98.755 \\
\hline 9.000 & 2.500 & 22.500 & 0.384 & 12.445 & 81.732 & 3.479 & 0.338 & 98.378 \\
\hline 10.000 & 2.500 & 25.000 & 0.236 & 7.890 & 81.937 & 7.984 & 0.456 & 98.503 \\
\hline 11.000 & 2.500 & 27.500 & 0.180 & 8.736 & 81.558 & 7.611 & 0.205 & 98.290 \\
\hline 12.000 & 2.500 & 30.000 & 0.115 & 7.214 & 81.430 & 9.459 & 0.183 & 98.401 \\
\hline 13.000 & 2.500 & 32.500 & 0.071 & 6.419 & 81.938 & 9.964 & 0.142 & 98.534 \\
\hline 14.000 & 2.500 & 35.000 & 0.097 & 6.051 & 81.410 & 10.741 & 0.215 & 98.514 \\
\hline 15.000 & 2.500 & 37.500 & 0.113 & 6.905 & 81.046 & 9.815 & 0.241 & 98.120 \\
\hline 16.000 & 2.500 & 40.000 & 0.392 & 7.095 & 83.022 & 6.891 & 0.358 & 97.758 \\
\hline 17.000 & 2.500 & 42.500 & 0.251 & 6.523 & 82.080 & 8.808 & 0.434 & 98.096 \\
\hline 18.000 & 2.500 & 45.000 & 0.055 & 5.797 & 81.846 & 10.735 & 0.097 & 98.530 \\
\hline 19.000 & 2.500 & 47.500 & 0.250 & 5.283 & 81.174 & 11.049 & 0.353 & 98.109 \\
\hline 20.000 & 2.500 & 50.000 & 0.064 & 5.167 & 80.727 & 12.200 & 0.178 & 98.336 \\
\hline 21.000 & 2.500 & 52.500 & 0.004 & 17.849 & 78.434 & 2.185 & 0.000 & 98.472 \\
\hline 22.000 & 2.500 & 55.000 & 0.001 & 20.719 & 77.639 & 0.165 & 0.000 & 98.524 \\
\hline 23.000 & 2.500 & 57.500 & 0.000 & 20.812 & 77.523 & 0.089 & 0.000 & 98.424 \\
\hline 24.000 & 2.500 & 60.000 & 0.394 & 14.057 & 80.415 & 2.977 & 0.149 & 97.992 \\
\hline 25.000 & 2.500 & 62.500 & 0.824 & 11.186 & 82.260 & 2.308 & 0.809 & 97.387 \\
\hline 26.000 & 2.500 & 65.000 & 0.128 & 10.769 & 83.330 & 3.497 & 0.122 & 97.846 \\
\hline 27.000 & 2.500 & 67.500 & 0.133 & 10.023 & 83.078 & 4.893 & 0.036 & 98.163 \\
\hline 28.000 & 2.500 & 70.000 & 0.612 & 10.917 & 81.147 & 4.250 & 0.609 & 97.535 \\
\hline 29.000 & 2.500 & 72.500 & 1.068 & 11.575 & 82.044 & 1.450 & 0.993 & 97.130 \\
\hline 30.000 & 2.500 & 75.000 & 0.371 & 12.019 & 81.451 & 2.967 & 0.431 & 97.239 \\
\hline 31.000 & 2.500 & 77.500 & 0.049 & 11.284 & 81.847 & 4.722 & 0.021 & 97.923 \\
\hline 32.000 & 2.500 & 80.000 & 0.009 & 9.551 & 82.206 & 6.625 & 0.000 & 98.391 \\
\hline 33.000 & 2.500 & 82.500 & 0.003 & 8.847 & 81.716 & 7.858 & 0.000 & 98.424 \\
\hline 34.000 & 2.500 & 85.000 & 0.002 & 8.091 & 81.604 & 8.912 & 0.000 & 98.609 \\
\hline 35.000 & 2.500 & 87.500 & 0.001 & 6.703 & 80.334 & 11.168 & 0.000 & 98.206 \\
\hline 36.000 & 2.500 & 90.000 & 0.001 & 7.084 & 79.648 & 11.427 & 0.000 & 98.160 \\
\hline 37.000 & 2.500 & 92.500 & 0.000 & 6.439 & 80.224 & 11.594 & 0.000 & 98.257 \\
\hline 38.000 & 2.500 & 95.000 & 0.000 & 5.497 & 79.976 & 12.469 & 0.000 & 97.942 \\
\hline
\end{tabular}


Trial $020 \quad 5 / 9 / 96$

Raw Data Run \#6

\begin{tabular}{|c|c|c|c|c|c|c|c|c|}
\hline Sample & $\begin{array}{c}\text { Cycle } \\
\text { Time } \\
(\mathrm{min})\end{array}$ & $\begin{array}{c}\text { Run Time } \\
(\mathrm{min})\end{array}$ & $\begin{array}{c}\mathrm{H}_{2} \\
\% \text { Vol. }\end{array}$ & $\begin{array}{c}\mathrm{O}_{2} \\
\% \text { Vol. }\end{array}$ & $\begin{array}{c}\mathrm{N}_{2} \\
\% \text { Vol. }\end{array}$ & $\mathrm{CO}_{2}$ & $\mathrm{CO}$ & Total \\
$\%$ Vol. & $\%$ Vol. \\
\hline 39.000 & 2.500 & 97.500 & 0.000 & 5.112 & 79.118 & 13.423 & 0.000 & 97.653 \\
\hline 40.000 & 2.500 & 100.000 & 0.000 & 16.439 & 77.759 & 3.925 & 0.000 & 98.123 \\
\hline 41.000 & 2.500 & 102.500 & 0.000 & 20.366 & 77.001 & 0.304 & 0.000 & 97.671 \\
\hline 42.000 & 2.500 & 105.000 & 0.000 & 14.710 & 77.783 & 4.892 & 0.000 & 97.385 \\
\hline 43.000 & 2.500 & 107.500 & 0.000 & 6.030 & 79.569 & 12.070 & 0.000 & 97.669 \\
\hline 44.000 & 2.500 & 110.000 & 0.000 & 4.954 & 79.646 & 12.848 & 0.000 & 97.448 \\
\hline 45.000 & 2.500 & 112.500 & 0.000 & 4.717 & 79.939 & 13.173 & 0.000 & 97.829 \\
\hline 46.000 & 2.500 & 115.000 & 0.000 & 3.632 & 80.006 & 13.703 & 0.000 & 97.341 \\
\hline 47.000 & 2.500 & 117.500 & 0.000 & 3.765 & 79.724 & 13.634 & 0.000 & 97.123 \\
\hline 48.000 & 2.500 & 120.000 & 0.000 & 3.634 & 79.907 & 13.616 & 0.000 & 97.157 \\
\hline 49.000 & 2.500 & 122.500 & 0.000 & 3.052 & 79.703 & 14.025 & 0.000 & 96.780 \\
\hline 50.000 & 2.500 & 125.000 & 0.000 & 2.949 & 79.641 & 14.240 & 0.000 & 96.830 \\
\hline 51.000 & 2.500 & 127.500 & 0.000 & 3.057 & 81.152 & 14.364 & 0.000 & 98.573 \\
\hline 52.000 & 2.500 & 130.000 & 0.000 & 19.930 & 77.917 & 0.748 & 0.000 & 98.595 \\
\hline 53.000 & 2.500 & 132.500 & 0.000 & 20.789 & 77.659 & 0.107 & 0.000 & 98.555 \\
\hline 54.000 & 2.500 & 135.000 & 0.000 & 20.765 & 77.413 & 0.081 & 0.000 & 98.259 \\
\hline 55.000 & 2.500 & 137.500 & 0.000 & 15.521 & 77.848 & 3.812 & 0.000 & 97.181 \\
\hline
\end{tabular}


Trial $021 \quad 5 / 10 / 96$

Raw Data Run \#7

\begin{tabular}{|c|c|c|c|c|c|c|c|c|}
\hline Sample & $\begin{array}{l}\text { Cycle } \\
\text { Time } \\
\text { (min) }\end{array}$ & $\begin{array}{c}\text { Run Time } \\
\text { (min) }\end{array}$ & $\begin{array}{c}\mathrm{H}_{2} \\
\% \mathrm{Vol}\end{array}$ & $\begin{array}{c}\mathrm{O}_{2} \\
\% \mathrm{Vol} \\
\end{array}$ & $\begin{array}{c}\mathrm{N}_{2} \\
\% \text { Vol. } \\
\end{array}$ & $\begin{array}{c}\mathrm{CO}_{2} \\
\% \text { Vol. } \\
\end{array}$ & $\begin{array}{c}\mathrm{CO} \\
\% \mathrm{Vol} \\
\end{array}$ & $\begin{array}{l}\text { Total } \\
\% \text { Vol. }\end{array}$ \\
\hline 1 & 2.67 & 2.67 & 0.000 & 21.181 & 79.327 & 0.049 & 0.000 & 100.557 \\
\hline 2 & 2.67 & 5.34 & 0.000 & 21.164 & 79.257 & 0.054 & 0.000 & 100.475 \\
\hline 3 & 2.67 & 8.01 & 0.000 & 21.139 & 79.153 & 0.048 & 0.000 & 100.340 \\
\hline 4 & 2.67 & 10.68 & 0.000 & 17.041 & 83.842 & 0.031 & 0.000 & 100.914 \\
\hline 5 & 2.67 & 13.35 & 0.000 & 17.324 & 83.418 & 0.037 & 0.000 & 100.779 \\
\hline 6 & 2.67 & 16.02 & 0.000 & 17.337 & 83.374 & 0.036 & 0.000 & 100.747 \\
\hline 7 & 2.67 & 18.69 & 0.000 & 16.864 & 83.824 & 0.031 & 0.000 & 100.719 \\
\hline 8 & 2.67 & 21.36 & 0.000 & 17.056 & 83.691 & 0.035 & 0.000 & 100.782 \\
\hline 9 & 2.67 & 24.03 & 0.619 & 7.381 & 83.556 & 8.733 & 1.738 & 102.027 \\
\hline 10 & 2.67 & 26.70 & 0.255 & 11.495 & 83.629 & 5.242 & 0.664 & 101.285 \\
\hline 11 & 2.67 & 29.37 & 0.602 & 10.053 & 83.921 & 6.275 & 0.764 & 101.615 \\
\hline 12 & 2.67 & 32.04 & $0.150^{\circ}$ & 11.571 & 83.900 & 5.950 & 0.147 & 101.718 \\
\hline 13 & 2.67 & 34.71 & 0.096 & 11.511 & \begin{tabular}{|l|}
83.669 \\
\end{tabular} & 6.385 & 0.054 & 101.715 \\
\hline 14 & 2.67 & 37.38 & 0.100 & 11.998 & 83.278 & 6.243 & 0.056 & 101.675 \\
\hline 15 & 2.67 & 40.05 & 0.040 & 11.378 & 83.465 & 6.766 & 0.000 & 101.649 \\
\hline 16 & 2.67 & 42.72 & 0.166 & 13.316 & 84.024 & 3.239 & 0.201 & 100.946 \\
\hline 17 & 2.67 & 45.39 & 0.030 & 12.421 & 82.436 & 6.298 & 0.037 & 101.222 \\
\hline 18 & 2.67 & 48.06 & 0.027 & 10.918 & 83.672 & 6.759 & 0.041 & 101.417 \\
\hline 19 & 2.67 & 50.73 & 0.027 & 10.771 & 83.701 & 6.910 & 0.000 & 101.409 \\
\hline 20 & 2.67 & 53.40 & 0.009 & 9.532 & 83.222 & 8.829 & 0.039 & 101.631 \\
\hline 21 & 2.67 & 56.07 & 0.003 & 18.546 & 79.182 & 1.646 & 0.000 & 99.377 \\
\hline 22 & 2.67 & 58.74 & 0.050 & 3.626 & 83.663 & 15.718 & 0.167 & 103.224 \\
\hline 23 & 2.67 & 61.41 & 0.006 & 18.398 & \begin{tabular}{|l}
78.714 \\
\end{tabular} & 2.289 & 0.000 & 99.407 \\
\hline 24 & 2.67 & 64.08 & 0.002 & 19.518 & 78.434 & 1.211 & 0.000 & 99.165 \\
\hline 25 & 2.67 & 66.75 & 0.042 & 19.644 & 78.238 & 1.045 & 0.057 & 99.026 \\
\hline 26 & 2.67 & 69.42 & 0.016 & 19.819 & 78.495 & 0.717 & 0.000 & 99.047 \\
\hline 27 & 2.67 & 72.09 & 0.000 & 19.967 & 78.268 & 0.724 & 0.000 & 98.959 \\
\hline 28 & 2.67 & 74.76 & 0.020 & 2.614 & 85.888 & 14.343 & 0.162 & 103.027 \\
\hline 29 & 2.67 & 77.43 & 0.017 & 3.810 & 84.522 & 14.377 & 0.190 & 102.916 \\
\hline 30 & 2.67 & 80.10 & 3.421 & 3.622 & 79.312 & 13.689 & 2.998 & 103.042 \\
\hline 31 & 2.67 & 82.77 & 0.001 & 6.019 & 84.620 & 11.594 & 0.000 & 102.234 \\
\hline 32 & 2.67 & 85.44 & 0.000 & 7.204 & \begin{tabular}{|l|}
83.047 \\
\end{tabular} & 11.852 & 0.000 & 102.103 \\
\hline 33 & 2.67 & 88.11 & 0.000 & 8.742 & 83.420 & 9.502 & 0.000 & 101.664 \\
\hline 34 & 2.67 & 90.78 & 4.207 & 6.020 & \begin{tabular}{|l|}
77.777 \\
\end{tabular} & 11.779 & 2.394 & 102.177 \\
\hline 35 & 2.67 & 93.45 & 0.003 & 10.233 & 83.193 & 7.866 & 0.000 & 101.295 \\
\hline 36 & 2.67 & 96.12 & 0.000 & 5.568 & 84.217 & 12.701 & 0.000 & 102.486 \\
\hline 37 & 2.67 & 98.79 & 0.000 & 4.659 & 84.321 & 13.675 & 0.000 & 102.655 \\
\hline 38 & 2.67 & 101.46 & 0.741 & 3.894 & 82.449 & 14.143 & 0.663 & 101.890 \\
\hline
\end{tabular}


Trial $021 \quad 5 / 10 / 96$

Raw Data Run \#7

\begin{tabular}{|c|c|c|c|c|c|c|c|c|}
\hline Sample & $\begin{array}{c}\text { Cycle } \\
\text { Time } \\
(\mathrm{min})\end{array}$ & Run Time & $\mathrm{H}_{2}$ & $\mathrm{O}_{2}$ & $\mathrm{~N}_{2}$ & $\mathrm{CO}_{2}$ & $\mathrm{CO}$ & Total \\
$\%$ Vol. & $\%$ Vol. & $\%$ Vol. & $\%$ Vol. & $\%$ Vol. & $\%$ Vol. \\
\hline 39 & 2.67 & 104.13 & 0.000 & 9.728 & 82.628 & 8.553 & 0.000 & 100.909 \\
\hline 40 & 2.67 & 106.80 & 0.008 & 7.008 & 83.689 & 10.358 & 0.000 & 101.063 \\
\hline 41 & 2.67 & 109.47 & 0.000 & 11.759 & 82.822 & 5.774 & 0.000 & 100.355 \\
\hline 42 & 2.67 & 112.14 & 0.000 & 11.238 & 82.816 & 6.312 & 0.000 & 100.366 \\
\hline 43 & 2.67 & 114.81 & 0.000 & 9.954 & 83.040 & 7.925 & 0.000 & 100.919 \\
\hline 44 & 2.67 & 117.48 & 0.000 & 9.065 & 82.035 & 10.021 & 0.000 & 101.121 \\
\hline 45 & 2.67 & 120.15 & 0.000 & 7.216 & 82.181 & 12.137 & 0.000 & 101.534 \\
\hline 46 & 2.67 & 122.82 & 0.000 & 7.360 & 81.270 & 12.843 & 0.000 & 101.473 \\
\hline 47 & 2.67 & 125.49 & 0.000 & 4.501 & 81.710 & 15.992 & 0.000 & 102.203 \\
\hline 48 & 2.67 & 128.16 & 0.000 & 5.169 & 82.196 & 14.639 & 0.000 & 102.004 \\
\hline 49 & 2.67 & 130.83 & 0.000 & 6.461 & 81.649 & 13.529 & 0.000 & 101.639 \\
\hline 50 & 2.67 & 133.50 & 0.000 & 7.046 & 82.101 & 12.408 & 0.000 & 101.555 \\
\hline 51 & 2.67 & 136.17 & 0.001 & 10.259 & 79.958 & 9.938 & 0.000 & 100.156 \\
\hline 52 & 2.67 & 138.84 & 0.001 & 20.246 & 77.590 & 0.452 & 0.000 & 98.289 \\
\hline 53 & 2.67 & 141.51 & 0.001 & 20.912 & 78.506 & 0.084 & 0.000 & 99.503 \\
\hline 54 & 2.67 & 144.18 & 0.001 & 20.942 & 78.629 & 0.067 & 0.000 & 99.639 \\
\hline 55 & 2.67 & 146.85 & 0.001 & 20.941 & 78.570 & 0.069 & 0.000 & 99.581 \\
\hline
\end{tabular}


Trial $022 \quad 5 / 13 / 96$

Raw Data Run \#8

\begin{tabular}{|c|c|c|c|c|c|c|c|c|}
\hline Sample & $\begin{array}{c}\text { Cycle } \\
\text { Time } \\
(\mathrm{min})\end{array}$ & $\begin{array}{c}\text { Run Time } \\
(\mathrm{min})\end{array}$ & $\begin{array}{c}\mathrm{H}_{2} \\
\% \text { Vol. }\end{array}$ & $\begin{array}{c}\mathrm{O}_{2} \\
\% \text { Vol. }\end{array}$ & $\begin{array}{c}\mathrm{N}_{2} \\
\% \text { Vol. }\end{array}$ & $\begin{array}{c}\mathrm{CO}_{2} \\
\% \text { Vol. }\end{array}$ & $\begin{array}{c}\mathrm{CO} \\
\% \text { Vol. }\end{array}$ & $\begin{array}{c}\text { Total } \\
\% \text { Vol. }\end{array}$ \\
\hline 39 & 2.67 & 104.13 & 0.000 & 21.322 & 79.654 & 0.039 & 0.000 & 101.015 \\
\hline 40 & 2.67 & 106.80 & 0.000 & 21.328 & 79.586 & 0.044 & 0.000 & 100.958 \\
\hline 41 & 2.67 & 109.47 & 0.000 & 19.349 & 79.422 & 1.337 & 0.000 & 100.108 \\
\hline 42 & 2.67 & 112.14 & 0.000 & 21.011 & 78.576 & 0.069 & 0.000 & 99.656 \\
\hline 43 & 2.67 & 114.81 & 0.000 & 21.058 & 78.701 & 0.047 & 0.000 & 99.806 \\
\hline 44 & 2.67 & 117.48 & 0.000 & 21.128 & 78.865 & 0.045 & 0.000 & 100.038 \\
\hline 45 & 2.67 & 120.15 & 0.000 & 21.349 & 79.646 & 0.035 & 0.000 & 101.030 \\
\hline 46 & 2.67 & 122.82 & 0.000 & 11.258 & 83.417 & 8.320 & 0.000 & 102.995 \\
\hline 47 & 2.67 & 125.49 & 0.000 & 11.379 & 83.310 & 8.234 & 0.000 & 102.923 \\
\hline 48 & 2.67 & 128.16 & 0.000 & 11.969 & 83.012 & 8.000 & 0.000 & 102.981 \\
\hline 49 & 2.67 & 130.83 & 0.000 & 13.190 & 82.468 & 7.162 & 0.000 & 102.820 \\
\hline 50 & 2.67 & 133.50 & 0.000 & 13.647 & 82.372 & 6.665 & 0.000 & 102.684 \\
\hline 51 & 2.67 & 136.17 & 0.000 & 13.727 & 82.036 & 6.808 & 0.000 & 102.571 \\
\hline 52 & 2.67 & 138.84 & 0.000 & 13.117 & 82.115 & 7.492 & 0.000 & 102.724 \\
\hline 53 & 2.67 & 141.51 & 0.000 & 14.417 & 81.598 & 6.457 & 0.000 & 102.472 \\
\hline 54 & 2.67 & 144.18 & 0.000 & 16.265 & 80.794 & 4.978 & 0.000 & 102.037 \\
\hline 55 & 2.67 & 146.85 & 0.000 & 20.219 & 79.843 & 1.188 & 0.000 & 101.250 \\
\hline 56 & 2.67 & 149.52 & 0.000 & 13.733 & 81.264 & 7.791 & 0.000 & 102.788 \\
\hline 57 & 2.67 & 152.19 & 0.000 & 21.363 & 79.714 & 0.072 & 0.000 & 101.149 \\
\hline 58 & 2.67 & 154.86 & 0.000 & 21.400 & 79.857 & 0.048 & 0.000 & 101.305 \\
\hline 59 & 2.67 & 157.53 & 0.000 & 21.382 & 79.971 & 0.040 & 0.000 & 101.393 \\
\hline
\end{tabular}

